INTER NATIONAL MONETARY FUND
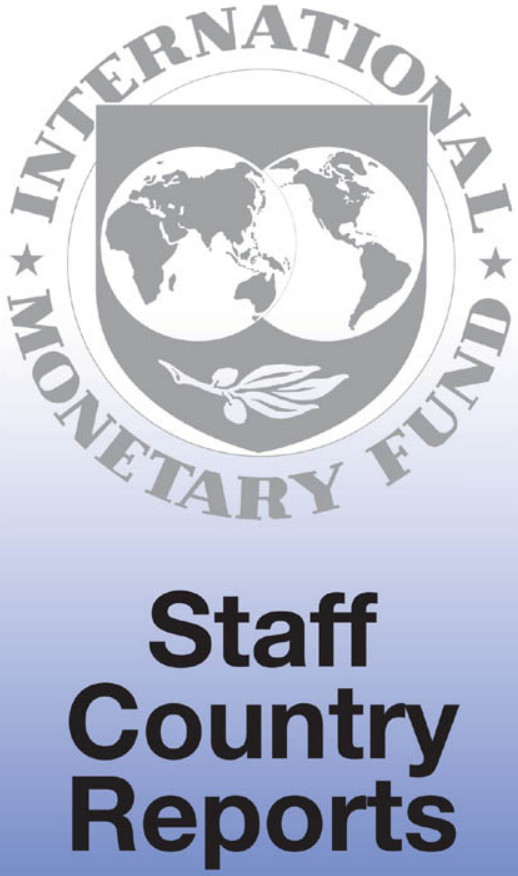


\title{
United States: Staff Report for the 2000 Article IV Consultation
}

As required under Article IV of its Articles of Agreement, the International Monetary Fund conducts periodic consultations with its member countries. In the context of the 2000 Article IV consultation with the United States, the following documents have been released and are included in this package:

- the staff report for the 2000 Article IV consultation, prepared by a staff team of the IMF, foilowing discussions that ended on June 19, 2000, with the officials of the United States on economic developments and policies. Based on information available at the time of these discussions, the staff report was completed on June 30, 200. The views expressed in the staff report are those of the staff team and do not necessarily reflect the views of the Executive Board of the IMF;

- a staff statement released the day of the Board discussion of July 21, 2000, updating information on recent economic developments;

- the Public Information Notice (PIN), which summarizes the views of the Executive Board as expressed during the July 21, 2000, Executive Board discussion of the staff report that concluded the Article IV consultation.

Further background documentation prepared by IMF staff for the consultation may be published separately at a later date. The policy of publication of Article IV staff reports and PINS allows for the deletion of market-sensitive information.

The Article IV staff report is published-both in hard copy and on the IMF"s website (http:/ /www.imf.org)-as part of a pilot project. To assist the IMF in evaluating the pilot project for release of Article IV staff reports, reader comments are invited prior to October 5, 2000, and may be sent by e-mail to Pilotproject@imf.org.

Copies of this report are available to the public from

International Monetary Fund - Publication Services

70019 th Street, N.W. - Washington, D.C. 20431

Telephone: (202) 6237430 - Telefax: (202) 6237201

E-mail: pub|ications@imf.org • Internet: http://www.imf.org

Price: $\$ 15.00$ a copy

\author{
International Monetary Fund \\ Washington, D.C.
}


INTERNATIONAL MONETARY FUND

UNITED STATES OF AMERICA

Staff Report for the 2000 Article IV Consultation

Prepared by the Staff Representatives for the 2000 Consultation with the United States

Approved by Claudio M. Loser and G. Russell Kincaid

June 29,2000

Contents

Executive Summary

I. Introduction

II. Economic Developments and Outlook.

A. Recent Economic Developments.

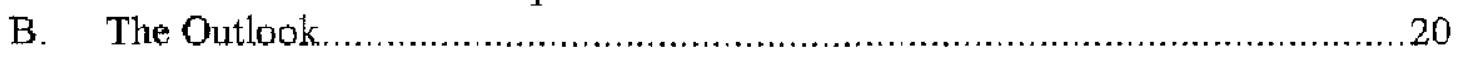

III. Policy Discussions

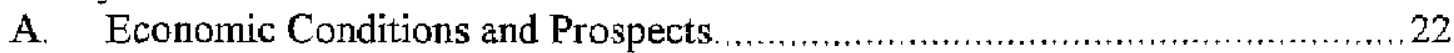

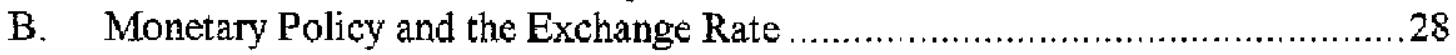

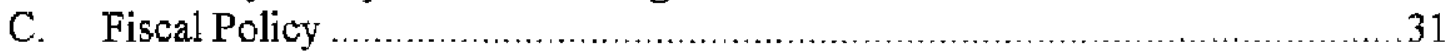

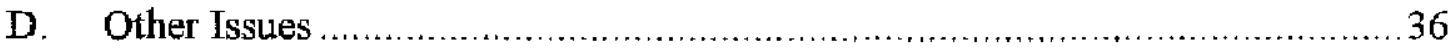

IV. Staff Appraisal 39

Boxes

1. The Contribution of Net Trade with the United States to

Economic Growth: An International Perspective ............................................. 7

2. The Distribution of Wealth Gains and the Effects on Consumption......................9

3. Stock Market Wealth and Household Consumption: A Cross-Country

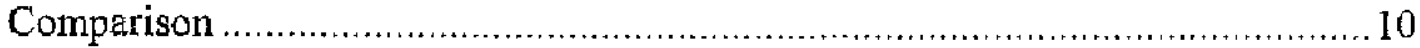

4. What is the "New Economy?" ……

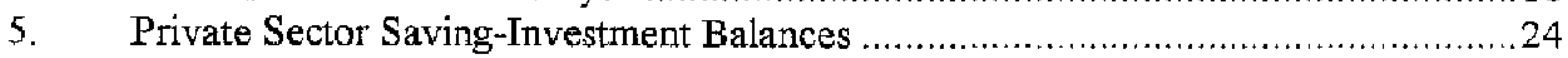

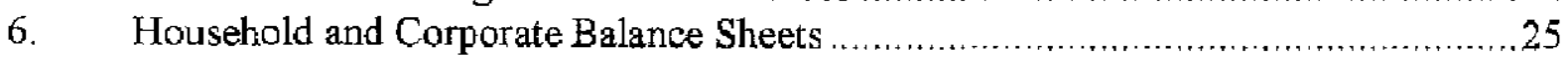

7. A Comparison of Japan in 1985-90 and the United States in 1994-99 _..............26

8. Recent Indicators of the Quality of Bank Credit and Banking

Sector Vulnerabilities 


\section{Appendices}

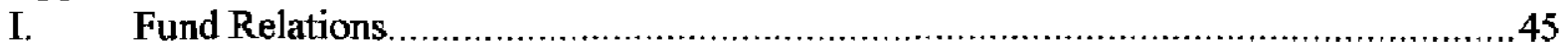

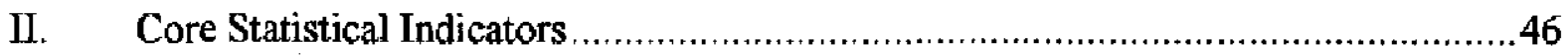

\begin{tabular}{|c|c|}
\hline 1. & Historical Economic Indicators. . \\
\hline 2. & Balance of Payments. \\
\hline 3. & Indicators of Economic Performance .... \\
\hline 4. & G-7 Countries: Labor Market Indicators .... \\
\hline 5. & Economic Outlook. \\
\hline 6. & "Harder Landing" Scenario. \\
\hline 7. & Fiscal Indicators, based on FY 2001 Budget. \\
\hline 8. & Fiscal Indicators, based on Mid-Session Review. \\
\hline 9. & Net Official Development Assistance Flows, 1998-99.. \\
\hline 10. & Outlays for Foreign Assistance on a Budget Basis \\
\hline 11. & Indicators of External and Financial Vulnerability. \\
\hline
\end{tabular}

\section{Figures}

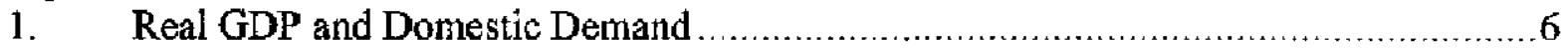

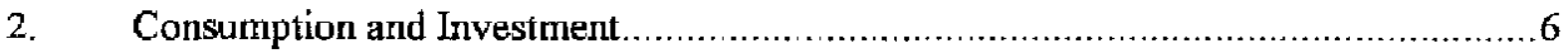

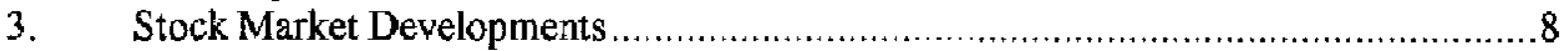

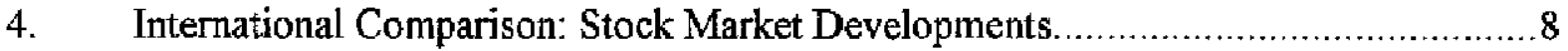

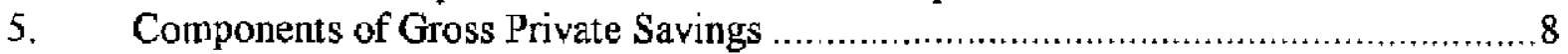

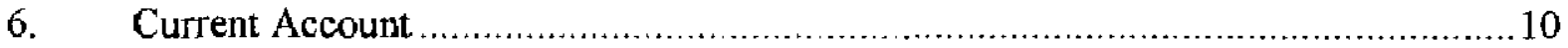

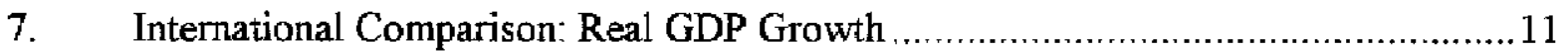

8. International Comparison; Current Account Balances ...........................................11

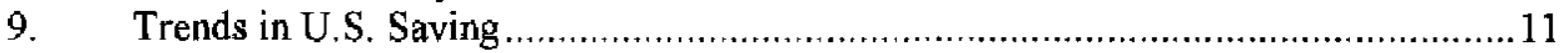

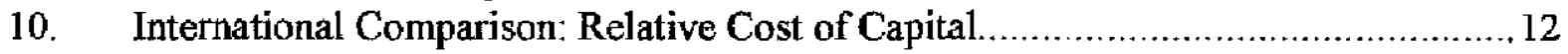

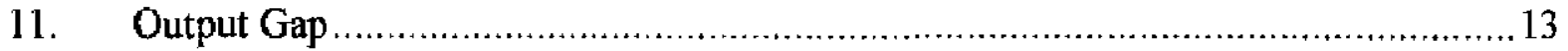

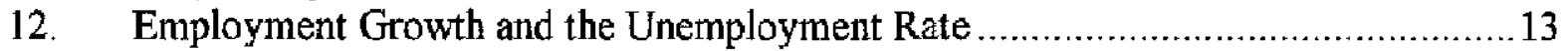

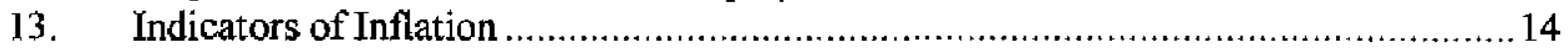

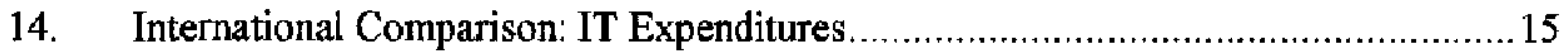

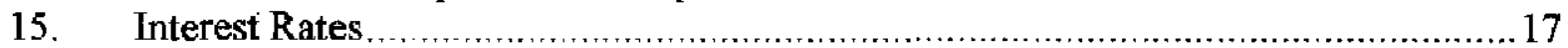

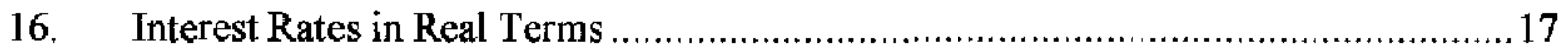

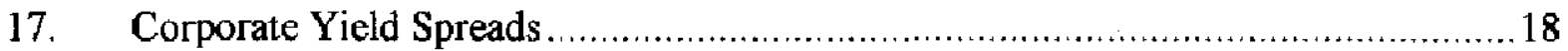

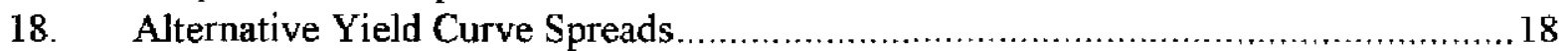

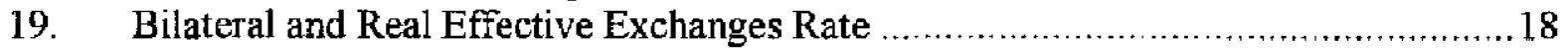

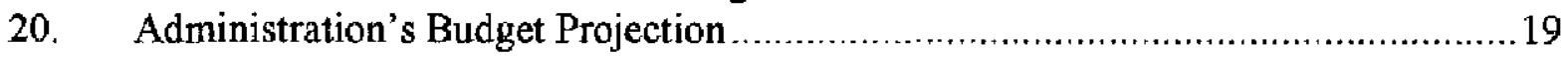




\section{EXECUTIVE SUMMARY}

\section{Economic setting}

- ReaI GDP grew by 4t/4 percent in 1999 and by 51/2 percent (annual rate) in the first quarter of 2000 , exceeding the staffs estimate of a $31 / 4$ percent growth rate for potential output. The current account deficit widened to 3.6 percent of GDP in 1999 from 2.5 percent of GDP in 1998, largely because of a further increase in the merchandise trade deficit.

- The unemployment rate has remained around 4 percent since the fourth quarter of 1999 - a 30-year low and well below the lower end of the range of most recent estimates of the NAIRU.

- Core-CPI inflation remained subdued at a 2 percent annual rate during 1999 and the first two months of 2000 . After picking up sharply in March, largely because of an increase in transportation services owing to higher fuel costs, core inflation settled back down to a 2 percent annual rate in April and May.

- The Federal Reserve tightened monetary policy over the last year, raising the federal funds rate by 175 basis points, including a 50 basis point increase in May 2000. The FOMC left the federal funds rate unchanged at its meeting in June.

- The unified federal budget balance moved into surplus in FY 1998 ( $\% / 4$ percent of GDP) for the first time since FY 1969, and the surplus increased to 11/2 percent of GDP in FY 1999. Estimates for FY 2000 suggest a surplus of just over 2 percent of GDP.

\section{Policy issues}

- The need to slow U.S. aggregate domestic demand growth to a sustainable noninflationary level, while other countries promote sustained expansion of their economies, in order to rebalance global demand and mitigate the risk of an abrupt reversal in the external imbalances among major industrial countries.

- Whether additional monetary policy action is likely to be required to ensure that inflation remains under control.

- Whether the accumulation of debt by U.S. households and corporations as equity prices have soared suggests there may be significant vulnerabilities to a sudden economic slowdown.

- Preserving the rising fiscal surpluses in prospect in order for fiscal policy to assist in restraining domestic demand growth in the near term and to address the looming financial needs of Social Security and Medicare in the longer term. 


\section{Staff views}

- A further tightening of monetary policy may be required to rein in U.S. demand growth and ensure that inflation remains under control. How much more interest rates will need to be increased will depend on how the economy responds to past and subsequent steps to tighten policy, and whether there are indications of emerging wage and price pressures in the period ahead.

- Fiscal policy also has an important role to play in restraining domestic demand growth in the near term. By helping to raise the level of national saving, maintaining a tight fiscal position would also help to ensure an orderly correction in the current account imbalance and in the real value of the dollar over the medium term.

- Eliminating the public debt over the next decade would be an important step in preparing the federal government to meet the costs of an aging population. However, to meet these obligations fully, the unified federal budget balance may need to remain in surplus for a while, even after the public debt has been retired. A reasonable medium-term fiscal policy approach consistent with this objective could be to adopt measures to eliminate the actuarial imbalances facing Social Security and Medicare HI (which would entail continuing to build surpluses in these accounts for an extended period), and then keep the remainder of the budget roughly in balance on average over the business cycle.

- Although at present there do not appear to be major vulnerabilities in the banking sector that could contribute to triggering a downturn in U.S. economic activity, a pre-emptive approach to supervision needs to be maintained to limit the scope for potential future financial distress. 


\section{INTRODUCTION}

1. The staff report for the previous Article IV consultation discussions was considered by the Executive Board on July 30, 1999 (EBM/99/85). ${ }^{2}$ Executive Directors noted that the United States had been the principal engine of growth during and in the aftermath of the period of global turbulence, and that U.S. monetary policy had played a key role in stabilizing international financial markets. In the period ahead, however, Directors agreed that U.S. growth would need to slow to a rate more in line with the economy's long-run potential. Although the performance of the U.S. economy had been remarkable, Directors cautioned that there were significant risks to the outlook, including large gains in wealth that had fueled strong consumption; a sharp widening in the current account deficit owing to the rapid pace of domestic demand growth and the appreciation of the dollar; and a reversal of some of the factors - such as declining commodity prices-which had contributed to the favorable inflation performance. Unless there were evidence that the strength of demand growth was abating, the authorities might need to tighten monetary policy further to ensure that the expansion remained on a sustainable, non-inflationary path. Directors supported efforts to preserve a substantial portion of the federal budget surpluses over the medium term. Moreover, Directors stressed that prompt measures were needed to address the long-term imbalances facing Social Security and Medicare. Directors also agreed that the appreciation of the U.S. dollar had sparked a worrisome degree of protectionist sentiment, and emphasized that these pressures should be resisted.

\section{ECONOMIC DEVELOPMENTS AND OUTLOOK}

\section{A. Recent Economic Developments}

2. Economic activity in the United States continued briskly during 1999, and the current expansion entered its 111th month in June 2000, the longest economic expansion

${ }^{1}$ The discussions for the 2000 Article IV consultation with the United States took place in Washington, D.C. during May and June. The staff team comprised D. Goldsbrough, S. Dunaway, M. Leidy, V. Arora, M. Cerisola, P. De Masi, M. Kaufman, and A. Matzen (all WHD). The Managing Director, the First Deputy Managing Director, and Mr. Loser took part in the concluding discussions with Federal Reserve Board Chairman Greenspan, and Treasury Secretary Summers. Ms. Lissakers, Executive Director for the United States, and Mr. Abbott, Advisor to the U.S. Executive Director, attended the meetings. Comprehensive economic data are available for the United States on a timely basis. The United States has subscribed to the Fund's Special Data Dissemination Standard and has submitted metadata, which have been posted on the Fund's Data Standards Bulletin Board.

${ }^{2} \mathrm{SM} / 99 / 159,7 / 6 / 99$ and the selected issues paper SM/99/164, 7/12/99. 
on record ${ }^{3}$ The economy grew at a

Figure 1, Lifited States; Real GDP and Dorrestic Demand

blistering pace of $6 \frac{1}{2}$ percent in the second half of 1999 , bringing growth for the year to $4 \frac{1 / 4}{4}$ percentthe fourth consecutive year that growth has been around 4 percent. Growth slowed only slightly to around a $5 \frac{1}{2} 2$ percent annual rate in the first quarter of 2000 (Table 1 . Figure 1). Some recent indicators provide early signs of moderating growth in the second quarter as the growth of consumer spending, home (Penceiliage chanect. sarne quarter previous year) purchases, and factory orders all slowed. With domestic demand growth exceeding supply, the current account deficit widened sharply in 1999, and as a result net exports to the United States continued to provide an important stimulus to growth in the rest of the world (Box 1).

3. As has been true for the last several years, robust personal consumption and investment spending have been the driving forces behind the rapid rate of growth in GDP (Figure 2). Personal consumption spending in 1999 increased by $51 / 4$ percent in real terms and at an annual rate of $71 / 2$ percent in the first quarter of 2000 . The strength of consumer spending most of which was concentrated in durable goods, has been sustained by the high level of

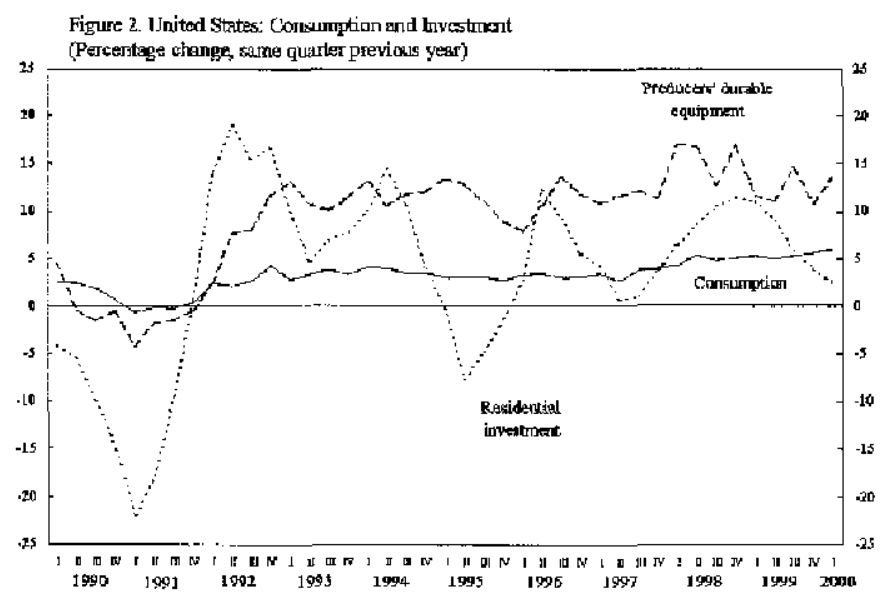
consumer confidence, gains in personal disposable income, and increases in household net wealth, with the latter largely reflecting gains in equity prices that have exceeded those in

\footnotetext{
${ }^{3}$ According to the National Bureau of Economic Research, previously the longest expansion on record was 106 months from February 1961 to December 1969.
} 


\section{Box 1. The Contribution of Net Trade with the United States to Economic Growth: An Intemational Perspective}

Because of its size and close linkages with the world economy, changes in the U.S. economy can have large effects on other countries. While the full effects of tracte on growth are more complicated, a simple measure of the impact on a country of trade with the United States is the direct contribution of net exports to the United States to the country's real GDP growth (captured by the change in net exports as a percent of GDP in the previous year). During 1992-98, net exports to the United States was an important contributot to growth in many industrial and developing countries, with Canada, Mexico, China, and some of the emerging Asign economies being the main beneficiaries.

Among the industrial countries, the contribution of nel exports to the United States to GDP growth was the largest in Canida, neflecting the very large share of the United States in Canada's trade, as well as the effects of a real depreciation of the Canadian dollar vis-à-vis the U.S. dollar. Among the European countries, net exports to the United States made only a modest contribution to growth, owing to the relatively small share of the United States in their foreign trade. In Australia, the contribution of net exports to the United States turned positive in 1997-98, partly the result of a large real depreciation of the Australian dollar .

In Asia, net exports to the United States helped to cushion the impact of the 1997-98 financial crisis on growth. The sharp decline in growth in Japan, as well as in Indonesia, Korea, Malaysia, and Thailand, was accompanied by large adjustnents in their external sectors as domestic demand slowed and exchange rates depreciated substantially. Contributions to growth from trade with the United States were largest for Thailand, Korea, China, and Malaysia, although only in the case of China was the impact of U.S. demand predominant.

In Argenlina and Brazil, a rising deficit with the United States was reflected in a negative contribution to growth. Hn Chile, a real depreciation of the peso against the U.S. doliar in 1998 contributed to a narrowing of the deficit with the United States. In Mexico, a substantial increase in net exports to the United States, provided a significant boost to the economic recovery after 1995. In Israel, the improvement in the overall trade balance in recent years was underpinned by a strengthening of net exports to the United States. In South Africa, the trade deficit with the United States continued to widen, reflected in a small negative contribution to growth.

Selected Countries: Contribution to Real GDP Grorth of Net Exerts of Goods and Nonfactor Services to the Unites States, 1992-98 (in percentage points, unless otherwise noted) l]

\begin{tabular}{|c|c|c|c|c|c|c|c|}
\hline & \multirow{2}{*}{\multicolumn{2}{|c|}{$\begin{array}{c}R=a \text { GDP growth } \\
\text { (in perceni) }\end{array}$}} & \multirow{3}{*}{$\begin{array}{l}\text { U.S. iJgdeftotal } \\
\text { trade (percent) } \\
1992-98\end{array}$} & \multicolumn{4}{|c|}{ Contribution to GDP grow th of ret exports: } \\
\hline & & & & \multicolumn{2}{|c|}{ Total } & \multicolumn{2}{|c|}{ To the United States } \\
\hline & $1992-96$ & $1997-98$ & & $1992-96$ & $1997-98$ & $1992-96$ & $1997-98$ \\
\hline $\begin{array}{l}\text { Canada } \\
\text { Europe }\end{array}$ & 2.5 & 3.5 & 72 & 0.8 & -0.4 & 0.5 & 0.5 \\
\hline Eranse & 1.1 & $2 . T$ & 7 & 0.4 & 0.4 & 0.1 & 0.1 \\
\hline Germany & 1.2 & 1.8 & 7 & 0.0 & 0.3 & 0.1 & 0.2 \\
\hline [taly & 1.2 & 1.4 & 5 & 1.1 & -1.0 & 0.0 & 0.0 \\
\hline United Kingdom & 2.4 & 2.8 & 75 & 0.1 & -1.2 & 0.0 & .0 .3 \\
\hline \multicolumn{8}{|l|}{ Latin America } \\
\hline Argenting & 50 & 6.0 & 19 & -0.8 & -0.9 & -0.2 & $-0,4$ \\
\hline Brazil & 34 & l.J & 25 & -1.6 & -1.5 & -0.6 & -0.7 \\
\hline Chile & 8.6 & 5.5 & 20 & $-3,0$ & -0.7 & -1.3 & 0.3 \\
\hline Maxico & 1.8 & 5.8 & 72 & 1.0 & -1.8 & 1.3 & 0.5 \\
\hline \multicolumn{8}{|l|}{ Asia and Pacific } \\
\hline Japan & 1.7 & -0.5 & 26 & -0.2 & 1.0 & 0.0 & 0.4 \\
\hline Australia & 40 & 4.5 & 15 & 0.1 & -0.5 & -0.3 & 0.1 \\
\hline China & 12.1 & 8.3 & 22 & -0.2 & 1.9 & 0.8 & 1.2 \\
\hline Indonesia & 7.6 & .4 .3 & 12 & -0.9 & 3.7 & 0.3 & 0.7 \\
\hline Korea & 7.0 & -0.4 & 16 & 0.0 & 8.9 & -0.2 & 1.6 \\
\hline Malaysia & 9.6 & 0.0 & 17 & -0.8 & 9.4 & 1.6 & 1.1 \\
\hline Theailand & 8.0 & -6.1 & 14 & -0.9 & 120 & 0.1 & 2.1 \\
\hline Istael & 5.7 & 2.3 & 24 & -1.4 & 1.0 & -0.2 & 0.2 \\
\hline South Africa & 1.9 & 1.6 & 9 & -0.7 & 0.1 & -0.1 & -0.1 \\
\hline
\end{tabular}

Sources: Based on thational accounts data from the World Economic Outlook; and bilateral trade data from the U.S. Department of Commercc, Burean of Economic Analysis. Bilateral data on non-factor services trade werc not available for several countries, including Eastem European countries and most conntries in Afrioa and the Middle East.

1/ Data refer to the anmual avernge during the petriod shown. 
most other major industrial countries (Figures 3 and 4, and Box 2). Most empirical evidence suggests that each additional dollar of equity wealth boosts household consumption by two to four cents over a two-year period; the staff's most recent estimate falls at the lower end of this range. The Federal Reserve estimates that consumption fueled by capital gains in excess of income growth has contributed about 1 percentage point to the overall annual growth in real domestic purchases over the past five years. ${ }^{4}$ Despite significant gains in stock prices in other major industrial countries, wealth effects on consumption have been bigger in the United States owing to the larger number of households holding equities and relatively higher estimates of U.S. spending out of wealth (Box 3). Moreover, with the increase in consumption outpacing income growth, personal saving as a share of GDP declined to a new low in the first quarter of 2000 (Figure 5).
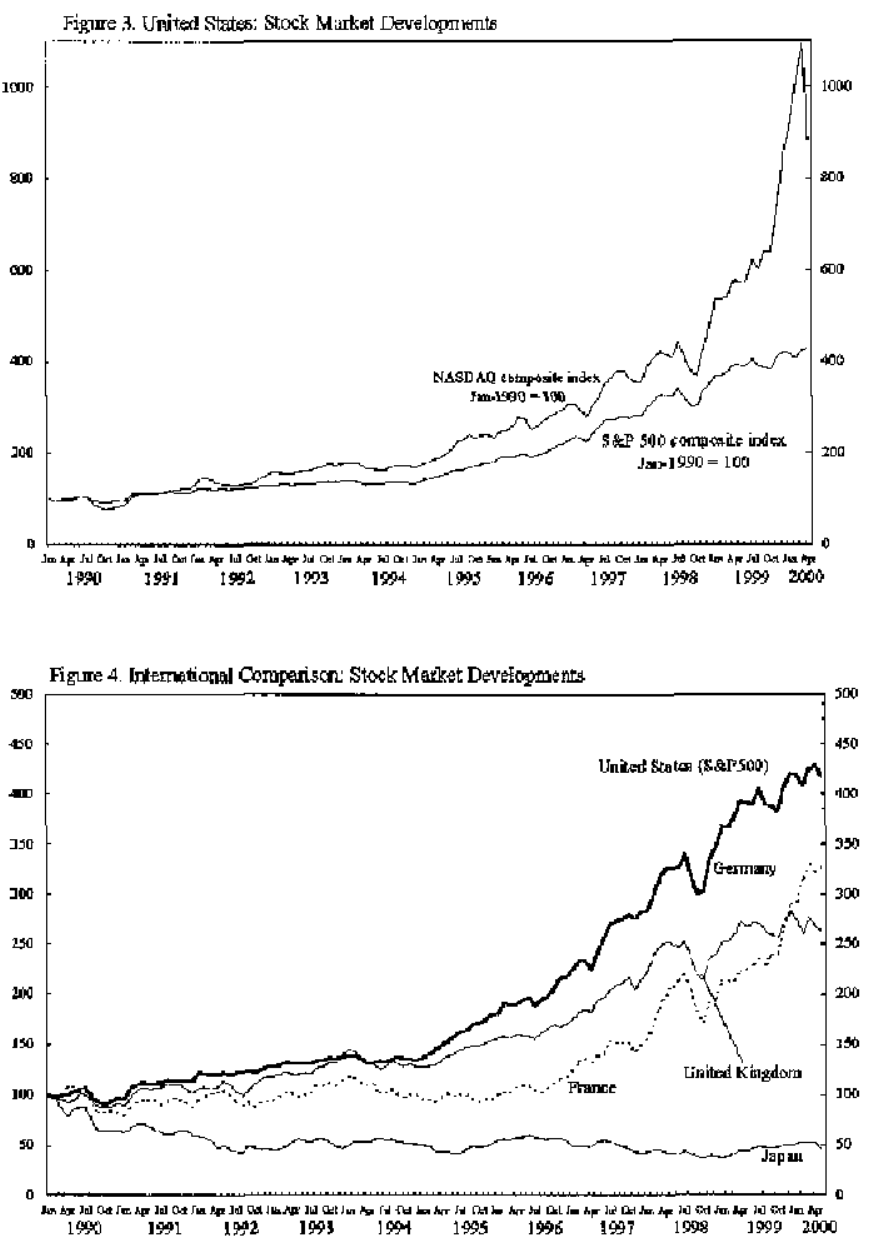

4. Investment spending increased by 8 percent in 1999, contributing about I percentage point to overall growth in GDP, and rose at an almost 20 percent annual rate in the first quarter of 2000. Spending on equipment and software-owing to strong business confidence and pressures on capacity, continued sharp

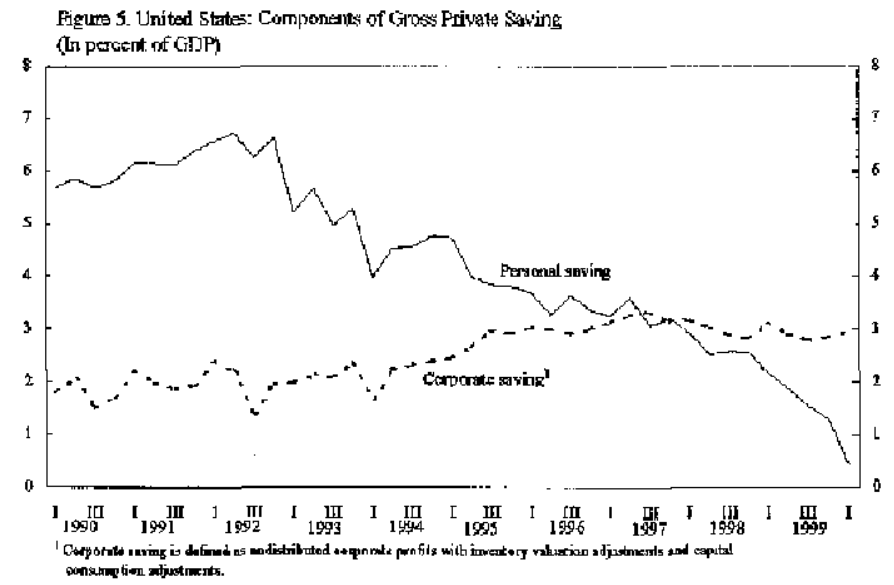

4 Alan Greenspan, "The Federal Reserve's Semiannual Report on the Economy and Monetary Policy," Testimony Before the Committee on Banking and Financial Services, U.S. House of Representatives, February 17, 2000. 


\section{Box 2. The Distribution of Wealth Gains and the Effects on Consumption}

The important role of financial wealth in driving consumption growth in the United States in recent years highlights the potential implications for macroeconomic activity and household batance sheets of a sharp correction in asset prices. The implications would depend in part on the distribution of the gains in wealth and consumption across households.

During 1995-98, the largest gains both in wealth and in consumption were concentrated among house-holds in the upper income groups. Households in the top two income groups (annual incomes of $\$ 50,000$ and above) accounted for 98 percent of the total gain in household wealth (see tabulation), and those in the top two quintiles of the income distribution accounted for 67 percent of the gain in household consumption.

The large share of upper income groups in the wealth gains owed partly to their dominant share in stock holdings. Although stock ownership became more widespread during 1995-98, the higher income groups continued to account for the bulk of the value of stock holdings. The proportion of households having direct or indirect holdings of stock rose from 40 percent of total households in 1995 to 49 percent in 1998 . The share of the top two income groups in the value of households stock holdings rose somewhat to 84 percent. The most important asset among households outside the top income group continued to be real estate. The modest rise in real estate prices compared with stock prices thus contributed to the unevenness in the distribution of wealth gains.

The gains in net wealth occurred simultaneously with an increase in household debt relative to estimated aftertax income (from 96 percent in 1995 to 105 percent in 1998). The top two income groups accounted for virtually all of the increase in household debt.

Houschold Wealth by Income Groups

(In billions of 1998 U.S. dollars)

\begin{tabular}{|c|c|c|c|c|c|c|c|}
\hline \multirow[b]{2}{*}{ Annual Household Income } & \multicolumn{3}{|c|}{ Total Net Worth } & \multicolumn{2}{|c|}{ Stocks 1/ } & \multicolumn{2}{|c|}{ Real Estate 2/ } \\
\hline & 1995 & 1998 & Change & 1995 & 1998 & 1995 & 1998 \\
\hline Below $\$ 10,000$ & 697 & 517 & -180 & 25 & 38 & 339 & 288 \\
\hline$\$ 10,000$ to $\$ 24,999$ & 2,019 & 2,178 & 159 & 189 & 302 & 1,194 & 1,252 \\
\hline$\$ 25,000$ to $\$ 49,999$ & 3,806 & 4,001 & 195 & 410 & 660 & 2,308 & 2,383 \\
\hline$\$ 50,000$ to $\$ 99,999$ & 5,300 & 7,123 & 1,757 & 725 & 1,391 & 2,824 & 3,790 \\
\hline$\$ 100,000$ and above & 10,344 & 15,245 & 4,902 & 1,886 & 3,661 & 2,467 & 3,426 \\
\hline Total & 22,233 & 28,985 & 6,752 & 3,235 & 6,053 & 9,132 & 11,140 \\
\hline
\end{tabular}

Sources: Data on wealth are based on the Board of Govemors of the Federal Reserve 1998 Survey of Consumer Finances: and federal Reserpe Bulletin (January 2000). Data on consumption referred to in the text above are from the U.S. Bureau of Labor Statistics (Consumer Expenditure Survey, various ycars).

$1 /$ Direct and indirect holdings of stock.

2/ Owner occupied and other residential real estate. 


\section{Box 3. Stock Market Wealth and Household Consumption: A Cross-Country Comparison}

In comparison with other countries, stock holdings are a relatively important part of household wealth in the United States. In 1998, the proportion of U.S. households that held slocks either directly or indirectly was 49 percent, compared with 7 percent in Germany and 19 percent in Italy.

In turn, the ratio of equity holdings in relation to household wealth is relatively high in the United States, and has contributed to the view that the wealth effect on consumption from a change in stock narket wealth may be larger in the United States than in other countries (sce tabulation).

Selected Countries: Households' Equity Holdings/Net Financial Wealth (in percent)

\begin{tabular}{lrr}
\hline & 1995 & 1998 \\
\hline United States & 31 & 35 \\
Canada & 37 & 45 \\
Germany & 9 & 13 \\
Italy & 24 & 33 \\
Japan & 15 & 111 \\
United Kingdom & 27 & 26
\end{tabular}

Source: OECD Economic Outlook, 1999, Table 58 .

1/ 1997.
Selected Countries: Effects on Private Consumption of a 10 Percent Decline in Stock Market Wealth (in percent) $1 /$

\begin{tabular}{lc}
\hline United States & -0.5 \\
Canada & -0.5 \\
France & -0.1 \\
Germany & -0.1 \\
Italy & 0.2 \\
Japan & -0.2 \\
United Kingdom & -0.4
\end{tabular}

Source: Boone, Giorno, and Richardson (1998), "Stock Market Fluctuations and Consumption Behavior," OECD Working Paper No. 208, Table 3 .

1/ The calculations are based on 1997 data and assume that the marginal propersity to consume out of wealth in all countries is the same as in the United States.

declines in computer prices, and the drive to adopt new technologies--accounted for most of the increase. Residential investment spending continued at a brisk pace. Although moderating in the second half of 1999 , reflecting an uptick in mortgage rates, it rebounded in the first quarter of 2000 .

\section{Providing a safety valve to the} rapid pace of domestic demand growth, net exports subtracted a little over 1 percentage point from GDP growth in

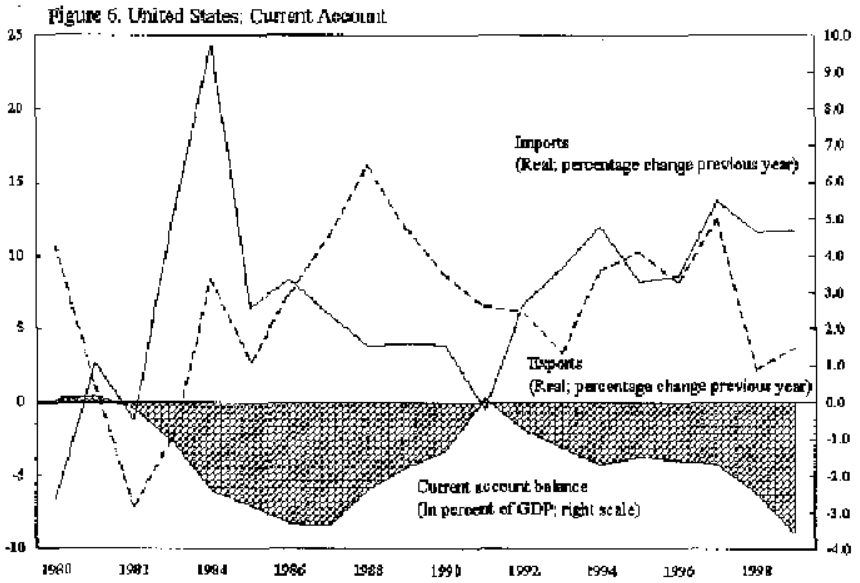
1999 and in the first quarter of 2000. The current account deficit widened to 3.6 percent of GDP ( $\$ 331$ billion) from 2.5 percent of GDP in 1998, largely because of a further increase in the merchandise trade deficit (Table 2 and Figure 6). Continued rapid import volume growth 
more than offset a pickup in export volume growth, which was driven by the economic recovery in partner countries during the second half of 1999 (Figure 7). The surplus on nonfactor services stayed unchanged as a percentage of GDP, while the deficit on net investment income increased slightly. In recent years, the major counterpart to large current account deficits in the United States has been persistently large current account surpluses in Japan and to a lesser extent in the Euro area, but in 1999 substantial improvements in the external positions of the developing countries corresponded to the further deterioration in the U.S external balance (Figure 8).

\section{The financing for the large}

U.S. current account deficit in 1999 mainly reflected net foreigh purchases of private $U . S$. securities-including large

Figue J. Intenationgl Compenisur: Real GDP [rowth (entual perient charge)

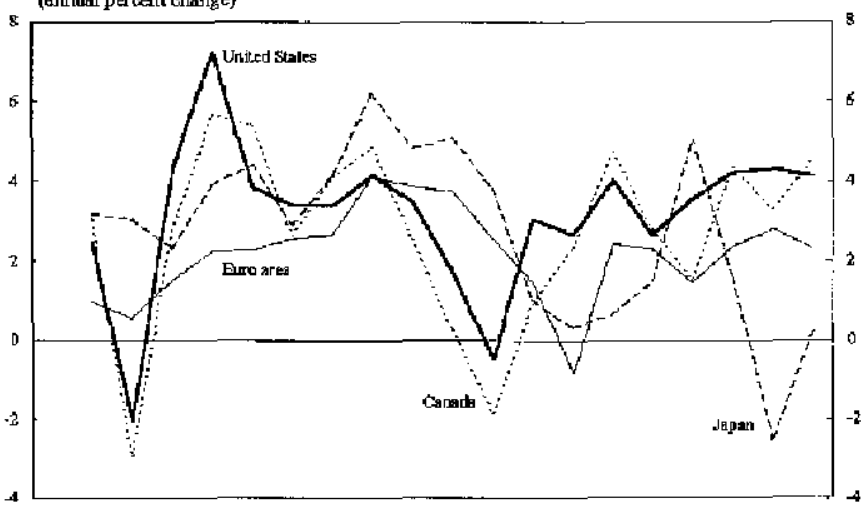

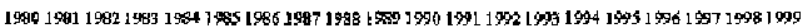

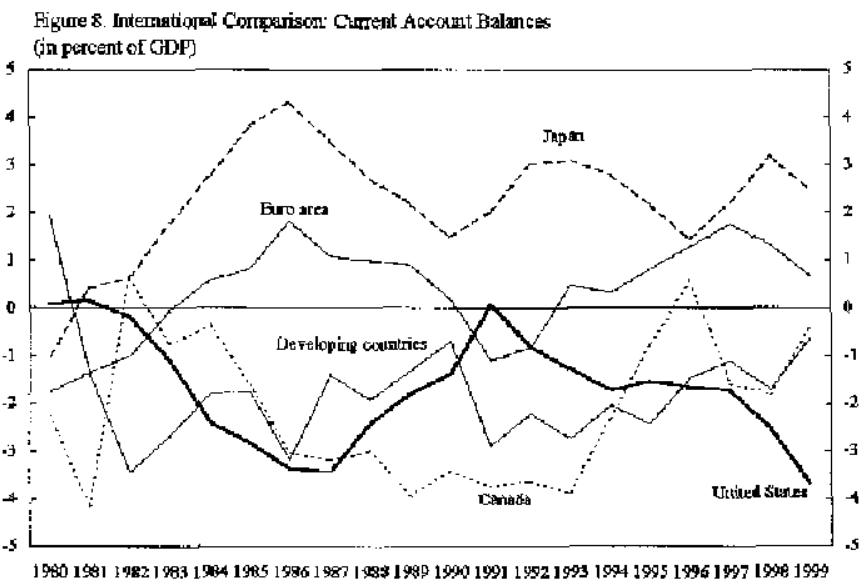

purchases of equities, corporate bonds, and government securities and net direct investment inflows. With the continued deterioration in the current account and strong capital inflows, the net foreign liability position of the United States rose from 14 percent of GDP at end-1998 to an estimated 17 percent of GDP at end-1999. Estimates suggest that foreign ownership now accounts for 25 percent of the stock of Treasury securities held by the public, about 20 percent of the corporate bond market, and 7 percent of the equity market; all these shares have increased significantly during the $1990 \mathrm{~s}$.

\section{Despite U.S. gross national} saving that is low in relation to historical standards and by international comparisons, the falling cost of capital equipment has helped the United States to achieve levels of real private investment that are substantially higher than in the past. After rising for the past five years, gross national saving as a share

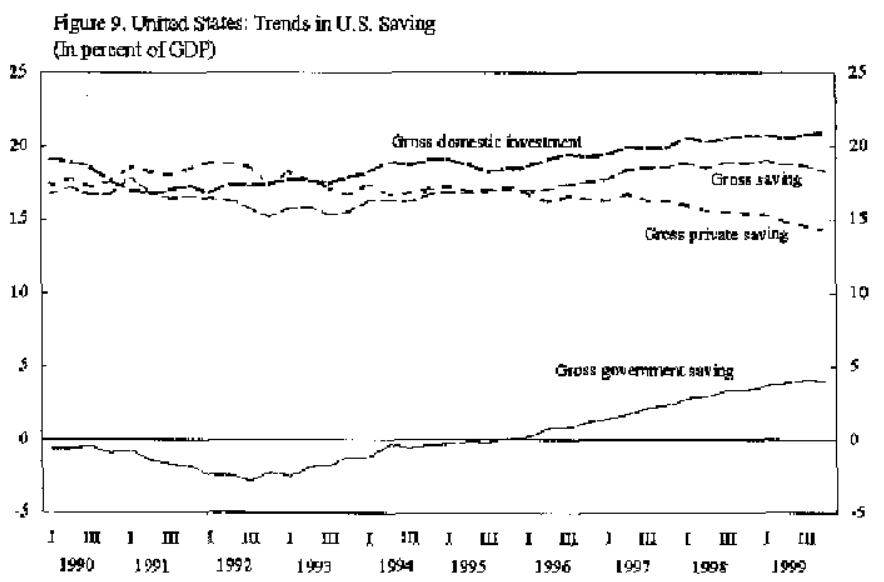


of GDP in 1999 remained unchanged at $183 / 4$ percent, reflecting a further decline in personal saving, which offset higher government saving (Figure 9). Measured in nominal terms, gross private domestic investment as a share of GDP in 1999 was substantially above its average for the 1970s and 1980s. Measured in real terms, the differences were even larger-more than 4 percentage points above its historical average. Real fixed private investment in the United States rose to 18 percent of real GDP in 1999, only slightly below the G-7 average (Table 3) ${ }^{5}$. This narrowing of the gap with respect to other G-7 countries (particularly with respect to Japan and Germany, the largest "investors" in the group) reflects the relatively cheaper cost of capital in the United States compared to most other G-7 countries, with the exception of Canada (Figure 10). ${ }^{6}$ It also reflects the larger proportion of U.S. fixed investment that represents purchases of computer equipment and software; real investment in information technology in the United States was one third of real fixed private investment in 1999, more than double the level of 1990. Over the period 1995-99, the price deflator for investment in computers and peripheral equipment fell at an average annual rate of 24 percent.

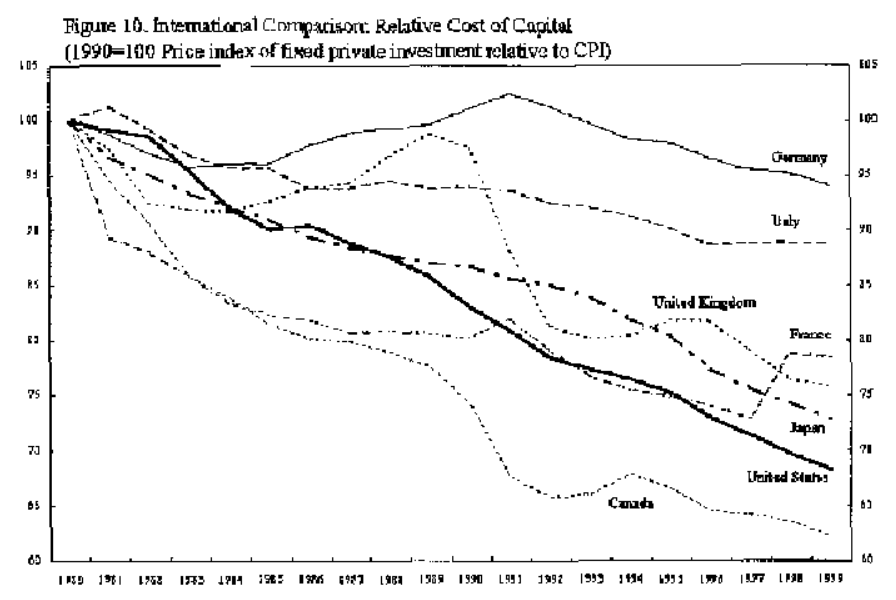

8. For the fourth consecutive year, annual growth in real GDP exceeded the staff's estimates of the long-term trend growth rate in potential output of about $31 / 4$ percent, and the unemployment rate fell to a 30 -year low (Figure 11). ${ }^{7}$ The unemployment rate at

\footnotetext{
${ }^{5}$ The narrowing of the real investment gap in part reflects differences in the definition of investment. The U.S. data now include computer software purchases by business as a part of investment, whereas other G-7 countries do not. Excluding software, fixed private investment in the United States was 16\%2 percent of adjusted real GDP in 1999.

${ }^{6}$ Methodologies for cost of capital measures differ across countries, in that some countries (the United States) use hedonic price deflators for computers, whereas others (Germany) do not.

${ }^{7}$ The recent benchmark revisions to the national income and product accounts revealed that real GDP growth had been stronger than previously thought. Based on the new data, the staff's estimate of the long-term trend growth in potential output was revised up to about $31 / 4$ percent from $21 / 2-23 / 4$ percent. However, other evidence based on gross domestic income data indicates that average annual output growth could be higher by as much as 0.4 percentage point. The forthcoming selected issues paper discusses these data revision.
} 
4.1 percent in May 2000 is below the lower range of most recent estimates of the NAIRU. ${ }^{8}$ Employment growth remained strong in 1999 , particularly in the service sector, which more than offset a decline in manufacturing employment (Figure 12) ${ }^{9}$ During the current expansion, employment growth has increased at an average annual rate of $13 / 4$ percent, far outpacing employment growth in other G-7 countries, with the exception of Canada (Table 4). Capacity utilization in the manufacturing sector edged down to around 80 percent in 1999 - owing to the weakness in export growth during the first part of the year and continued strong investment--but it increased in early 2000 , and held steady at $81 \frac{1}{2}$ percent in May 2000 , just below its historical average.

\section{Despite the high level of} resource utilization, core inflation remained largely subdued in 1999
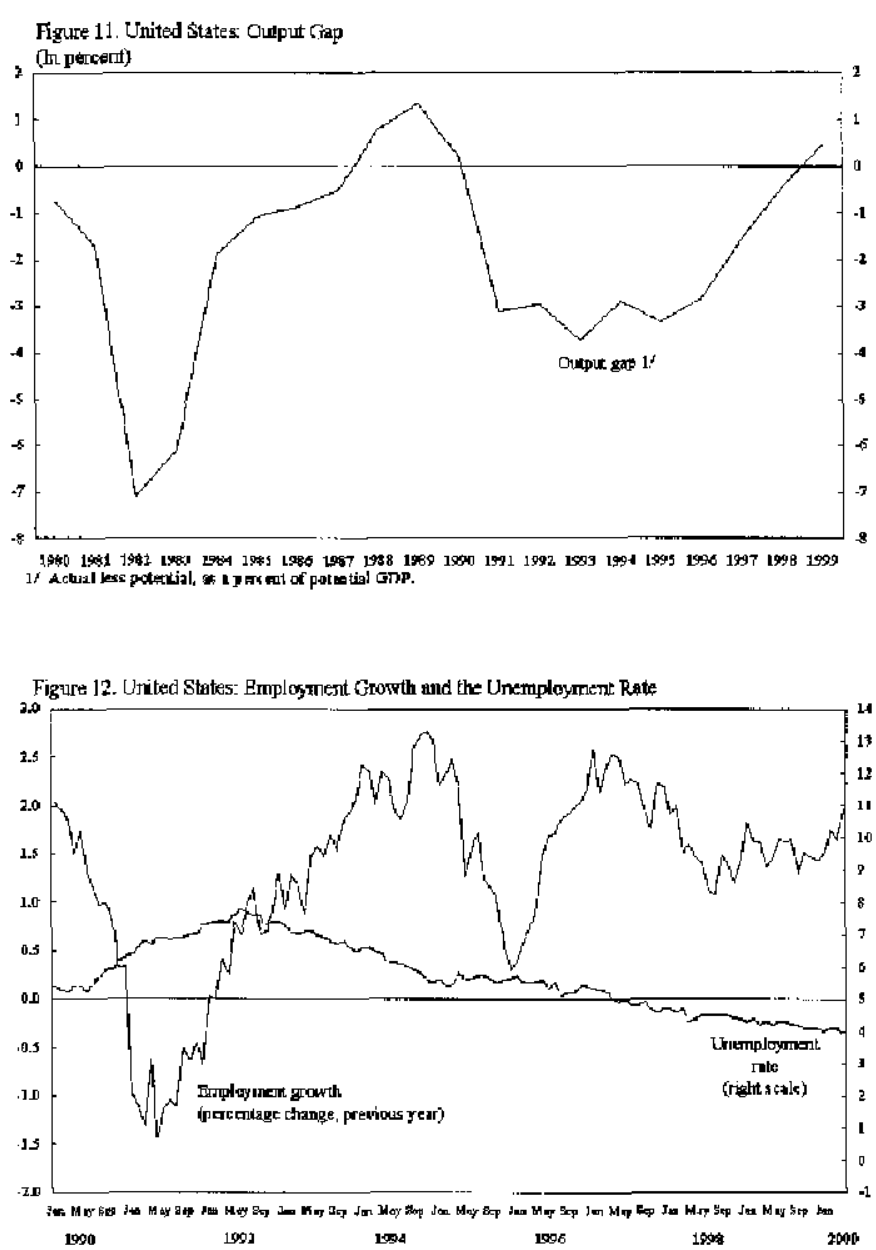

and early 2000, owing to strong gains in productivity and a continued slow rise in non-oil import prices, but more recent data provide a mixed picture about possible emerging price and wage pressures (Figure 13). Consumer price inflation rose to about 3 percent in 1999 and the first two months of 2000 , largely the result of higher energy prices. Increases in the core-CPI (excluding food and energy) remained subdued at a 2 percent annual rate. In March, however, core-CPI inflation picked up sharply primarily because of an increase in transportation services owing to higher fuel costs, but it settled back down to a 2 percent annual rate in April and May as some of the previous increases in transportation were

${ }^{8}$ Estimates of the NAIRU generally fall in the range of $41 / 4$ to $6 \frac{1}{2}$ percent. See "Measures of Potential Output, NAIRU, and Capacity Utilization," in United States: Selected Issues, IMF Staff Country Report No. 99/101, September 1999.

${ }^{9}$ The forthcoming selected issues paper reviews recent employment growth and labor supply changes in the United States, comparing these developments to past decades and to developments in selected industrial countries. 
Inflation

(Percentage change, December over December)

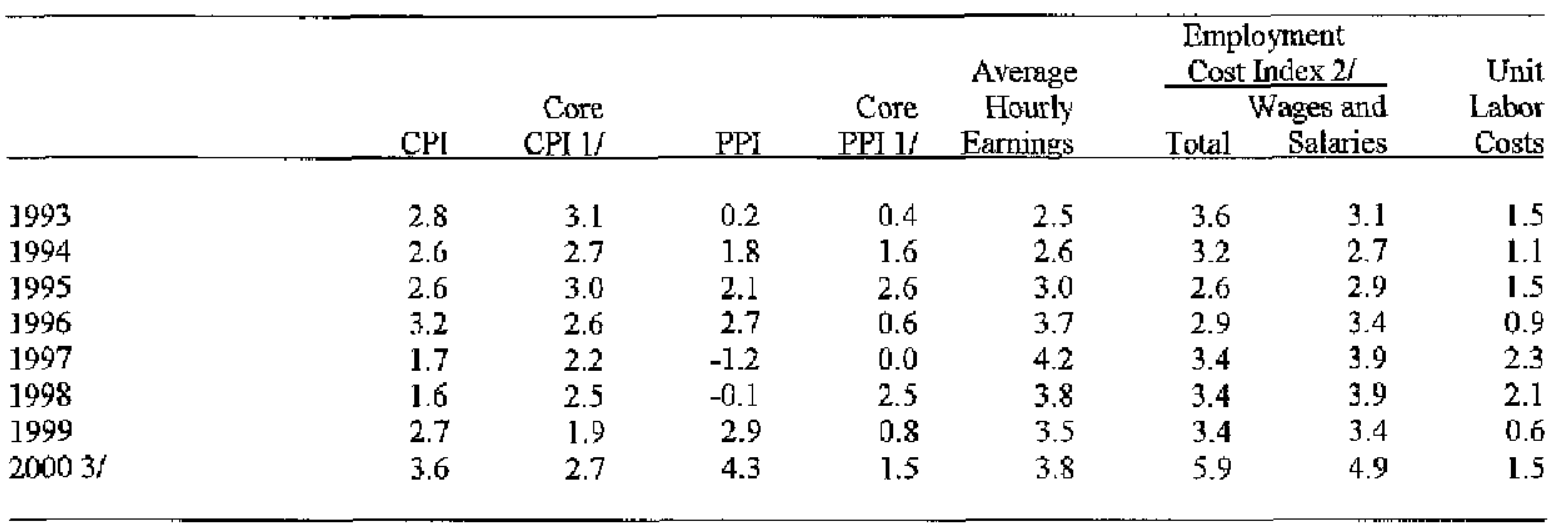

1/ Core inflation rates exclude changes in food and energy prices.

2/ Fourth quarter over fourth quarter.

3/ May 2000December 1999 annualized for CPI, PPI, and average hourly earnings; 2000QL/199Q4 anmualized for employment cost index, and unit labor costs.

reversed. The chain-type price index for personal consumption expenditures ( $\mathrm{PCE}$ ) increased by 2 percent in 1999 , while the corePCE rose by just $1 \frac{1}{2}$ percent. In the first quarter of 2000 , core-PCE inflation picked up slightly to $13 / 4$ percent. $^{10}$

10. Growth in wages and other labor compensation was moderate in 1999, with the employment cost index increasing at roughly the

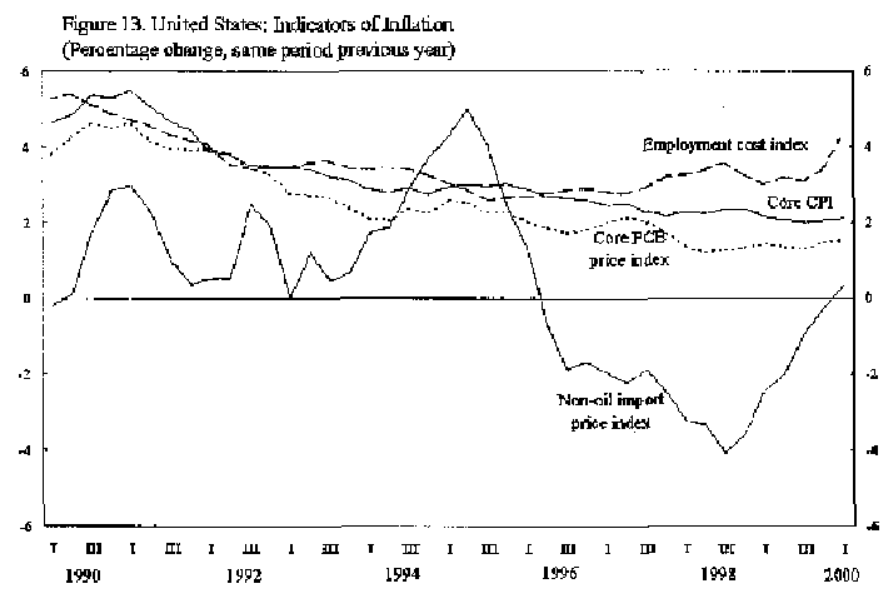
same rate as a year earlier. But, the index rose sharply in the first quarter of 2000 , advancing at an annual rate of nearly 6 percent, with a pickup in both wages and benefits costs. Growth in labor productivity (output per man hour) increased to $3 \frac{1}{2}$ percent during

${ }^{10}$ In the February 2000 Monetary Policy Report to Congress, it was noted that the FOMC had recently shifted from presenting a CPI-based inflation forecast to one based on the PCE price index. The PCE price index has a number of advantages over the CPI, including eliminating some of the upward bias associated with fixed-weight indexes like the CPI, and the use of weights based on a more comprehensive measure of expenditures. Despite the change in presentation, the FOMC continues to rely on a wide variety of aggregate price indices in assessing the inflation outlook. 
1999, from 3 percent during 1998 , with especially strong gains in the second half of the year. As a result, the growth in unit labor costs fell to $1 / 2$ percent in 1999 , down from 2 percent a year earlier. In the first quarter of 2000 , labor productivity growth slowed to an average annual rate of $21 / 2$ percent, and unit labor costs increased by about $11 / 2$ percent.

\section{The combination of continued robust growth and low inflation has led some} observers to conclude that a "new" economy has emerged in the United States, although interpretations of what is "new" differ (Box 4). Recent empirical evidence (discussed in the forthcoming background paper) suggests that the production and use of information technology (IT) explain much of the acceleration in labor productivity growth during the current expansion. Greater efficiencies achieved in producing computers and semiconductors have boosted productivity, which is evidenced by the plunging prices for these types of goods. These price declines have stimulated investment in information technology by other industries, contributing to capital deepening and further boosting labor productivity. However, claims that these changes have led to a "permanent" increase in productivity growth are premature. In the past, waves of technological innovations have permanently increased the level of productivity, but they have led to only temporary increases in productivity growth as the new technologies were adopted (or diffused) throughout the economy. Nevertheless, this process of adoption and implementation of new technology could play out over some time, giving rise to higher productivity growth for an extended period.

\section{From an international} perspective, the positive impact of new technologies has been more significant so far in the United States than in other industrial economies. This may in part reflect the greater relative importance of the computer and semiconductor industries in U.S, output. ${ }^{11}$ It may also reflect the greater flexibility of product and labor markets in the United States. This flexibilitywhich facilitates entry into new

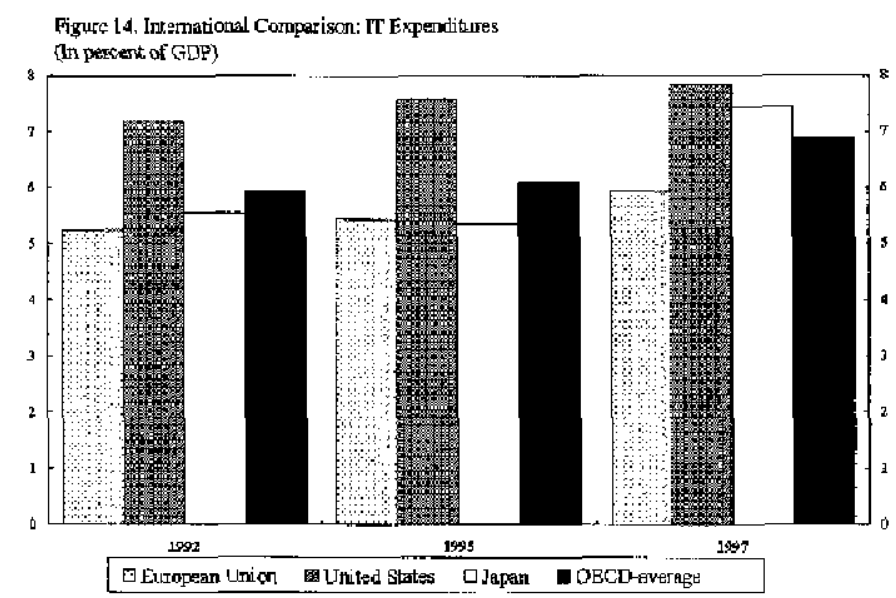

${ }^{11}$ For example, a large part of the more rapid growth in labor productivity in manufacturing in the United States relative to Canada in recent years can be attributed to the relatively larger share of computers and semiconductors in U.S. manufacturing output. A detailed comparison between the United States and Canada of productivity trends in the industrial sector is provided in "Productivity Trends in Canada," in Canada: Selected Issues, IMF Staff Country Report No. 00/34, March 2000. 


\section{Box 4. What is the "New Economy?"}

Strong economic growth combined with low inflation and a pickup in productivity growth has led many observers of U.S. economic conditions to proclaim the existence of a "new economy" in the United States. The adoption of new technologies and globalization are seen as altering underlying economic relationships. Despitc the attention that the term has received, there is little consensus on what is different and whether such differences have fundamentally changed the economy. The interpretations on what constitutes the "new economy" can be organized into three different but related categories:

- The long-run growth view. In this interpretation, highcr long-term growth is achieved owing to a permanently higher growth rate in productivity that stems primarily from the adoption of and continued innovation in information technology (IT), as well as from the cffects of globalization, and deregulation. Empirical evidence suggests that there is a link between using and producing computers and the pickup in labor productivity in the second half of the 1990s. However, based on available data, it is not possible to conclude that the shift to higher productivity growth is sustainable. The substantial increase in productivity associated with IT experienced in recent years may simply represent a one-time period of transition to a higher level of productivity because of a major change in technology. This can be considered an "old economy" process, in the sense that it represents the traditional process of development, adoption, and diffusion of new technologies.

- The resource utilization view. This version of the "new economy" is based on the observation that during the recent expansion unemployment has declined below most estimates of NAIRU without spurring inflation. It is argued that inflationary pressures in the United States have remained subdued because of globalization and IT, which has increased productivity, and efficiency. For example, better access to information allows firms to improve inventory management and new capacity can be brought on line with shorter lead times owing to streamlining of the design and delivery process. Moreover, because actual productivity is increasing faster than what workers perceive, wage demands are muted. Accordingly, labor and other utilization rates can be higher without triggering inflationary pressures, and it appears as though NAIRU has declined. At present, however, it is extremely difficult to disentangle whether the decline in NAIRU is permanent or simply related to temporary factors, such as thc period of time it takes for workers to incorporate higher trend productivity into wage demands. In addition, positive supply shocks - for example, the past weakness in commodity prices, the strength of the U.S. dollar, and restrained health care costsmay have temporarily reduced inflationary pressures, but have not changed any of the underlying relationships in the economy.

- The positive feedback view. In this view, the "new economy" is characterized by a pickup of total factor productivity growth in various sectors which is based on the adoption of IT and results in increasing returns to scale, other network economies, and positive spillover effects. In other words, investment in IT in one firm improves the productivity of other firms, as they are able to work together more efficiently. Although there is anecdotal evidence, there is to date little solid empirical evidence that such positive feedback effects across industries are more important now than in the past. 
markets, the introduction of new products, and the re-organization of work processesfosters an environment conducive to reaping the benefits from adopting the new information technology. Among the major industrial countries, the United States has consistently ranked furst in IT expenditures as a percent of GDP, although the differences appear to have narrowed recently (Figure 14).

13. By mid-1999, concerns about persistent domestic demand growth in excess of the growth in potential output and further tightening in labor markets prompted the Federal Reserve to tighten monetary policy. Over the period June 1999 to May 2000 , the Federal Reserve raised the federal funds rate by 175 basis points, including successive increases at four consecutive FOMC meetings,

culminating in a 50 basis point increase in May. At its June meeting, the FOMC decided to leave the federal funds rate unchanged, but in its announcement following the meeting, the FOMC indicated that the risks continued to be weighted mainly toward conditions that may generate heightened inflationary pressures in the foreseeable future.

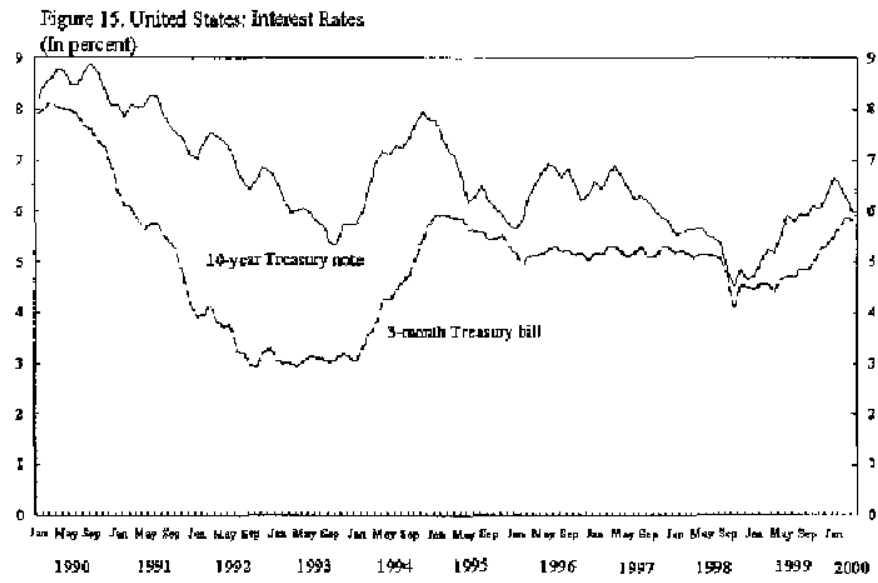

14. In the second half of 1999, as the federal funds target rate was raised, the yield curve flattened, with the spread between three-month and ten-year Treasury securities norrowing substantially (Figure 15). During the first quarter of 2000 , the yield curve beyond two years became inverted as the yields on longerterm Treasury bonds fell sharply. This development followed the Treasury's announcement that it

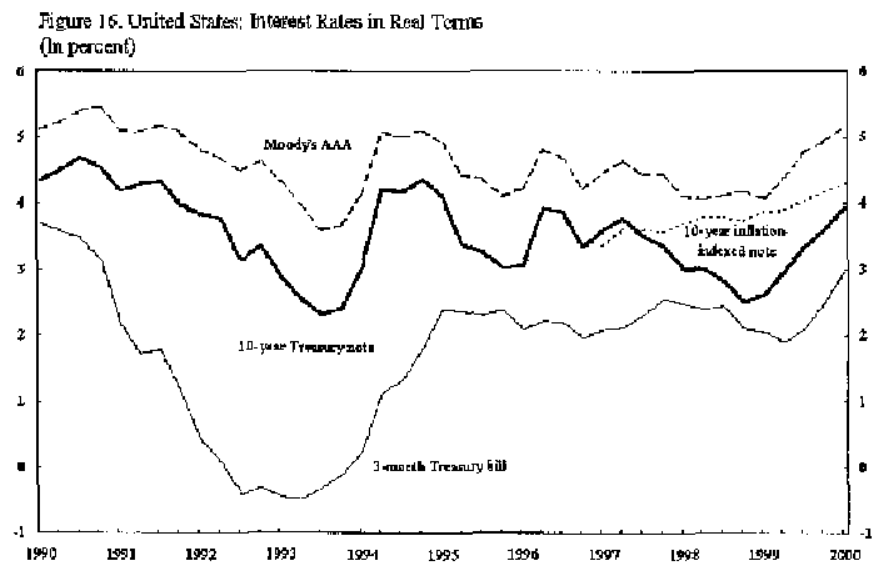
would begin to buy back Treasury securities, which was interpreted by market participants as implying that the supply of longer-term Treasuries would decline relative to shorter-term maturities: Real interest rates have risen over the past year, with an increased demand for funds possibly reflecting improved rates of return on investment in the United States (Figutes 16 and 17).

15. The recent behavior of the "traditional" yield curve suggests that the yields on longer-term Treasury securities will become a less useful benchmark for the risk-free interest rate, if the projected fiscal budget surpluses materialize and Treasury debt is 
retired over time. Increasingly, other fixed-income securities are being considered as alternative benchmarks, including interest rate swaps, federal government agency debt (for example, Fannie Mae, and Freddie Mac), and corporate debt. The spreads between three-month Treasury bills and these ten-year securities have also narrowed (Figure 18).

16. In real effective terms, the dollar appreciated by $3 \frac{1}{2}$ percent in 1999 and by a further $71 / 2$ percent in the first five months of 2000 (Figure 19). A 12 percent depreciation against the Japanese yen during 1999 was more than offset by a $14 \frac{1}{2}$ percent appreciation of the dollar against the euro. In the first five months of 2000 , the dollar appreciated modestly against the yen, but more sharply against the euro. In real effective terms, the dollar in May 2000 was 39 percent higher than its low in April-July 1995. According to the latest Coordinating Group on Exchange Rates (CGER) assessment, the dollar in mid-2000 is at least 20 percent stronger than its medium-run equilibrium level.

\section{The fiscal position strengthened} further during 1999, as the unified federal budget achieved a larger sarplus than in 1998-with most of the increase estimated to be structural (see Table 1)marking the first back-to-back budget surphuses in 40 years. The unified federal budget balance moved into surplus in FY 1998 ( $3 / 4$ percent of GDP) for the first time since FY 1969, and the surplus

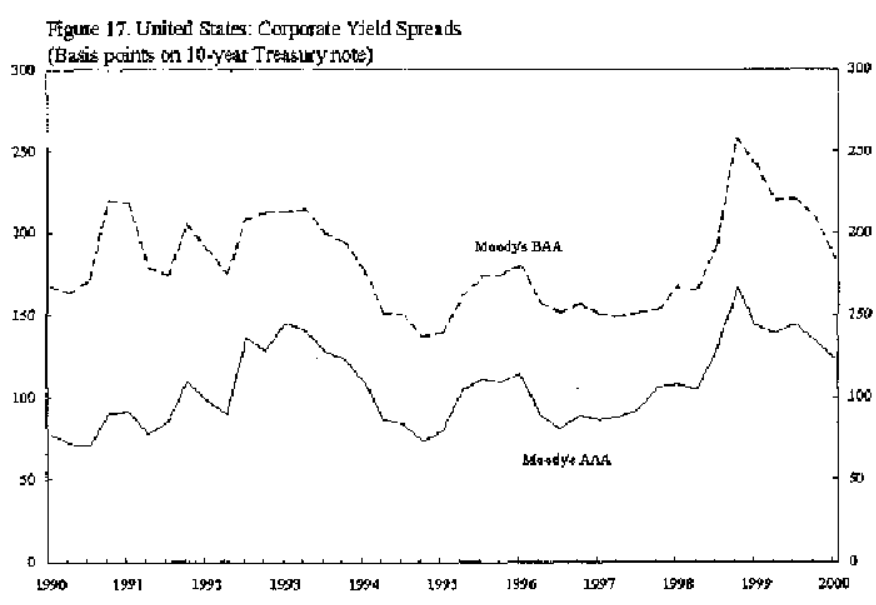

Figare 18 . United states; Altriative Yiekl Curve Spreads

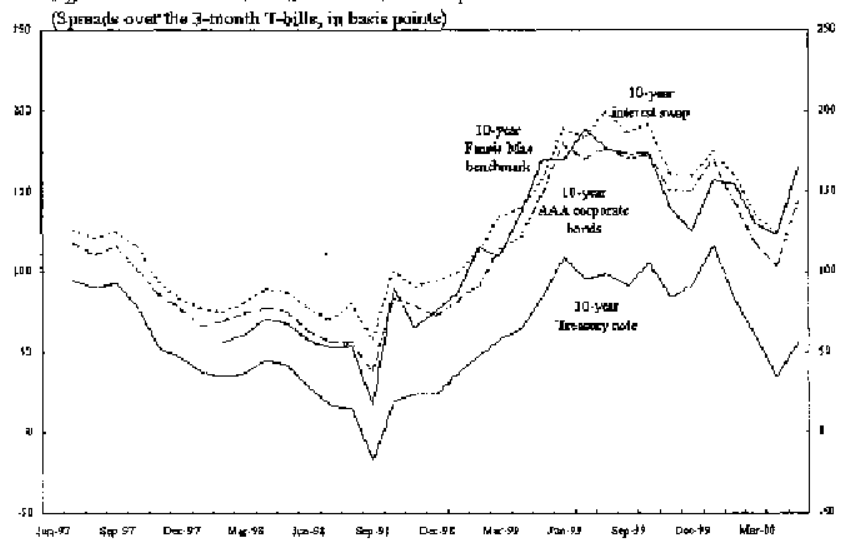

Figure 19. United States: Bìlateral and Real Effeetive Lxchange Rate (index $1990=100$ )

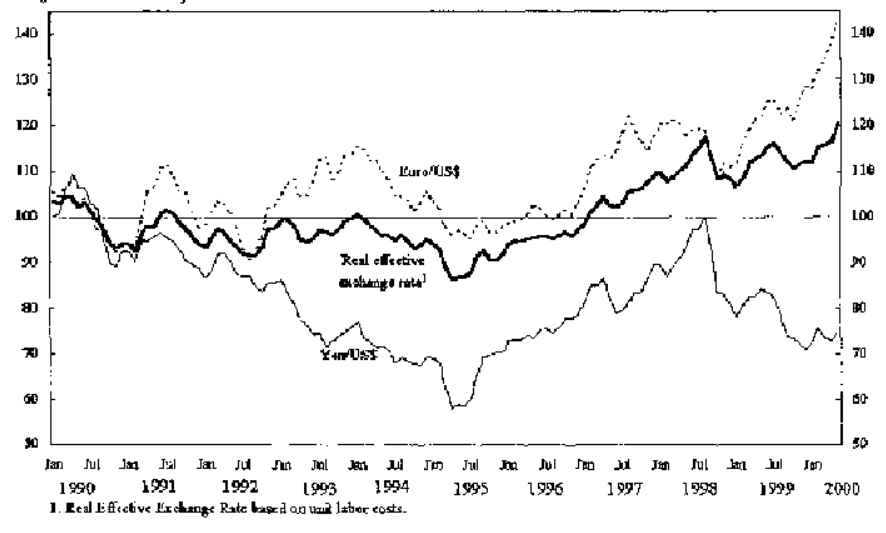


increased to $1 \frac{1}{2}$ percent of GDP ( $\$ 124$ billion) in FY 1999. ${ }^{12}$

Continuing the pattern of recent years, most of the increase in the unified surplus in FY 1999 reflected an increase in the onbudget balance. In the FY 2001 Budget issued in February 2000, the Administration estimated that the FY 2000 unified federal surplus would rise to $\$ 179$ billion (nearly 2 percent of GDP; Figure 20). In the Mid-Session Review of the

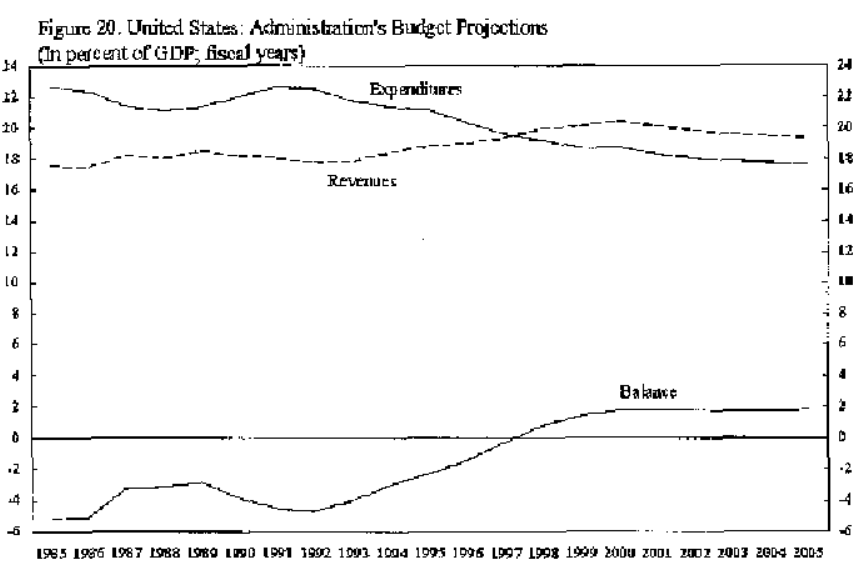

FY 2001 Budget released in late June 2000, the Administration revised its estimate of the FY 2000 surplus up to $\$ 224$ billion (21/4 percent of GDP). The steady improvement in the fiscal balance is in large part the outcome of policy measures enacted since 1992, chiefly the Omnibus Budget Reconciliation Act of 1993 (OBRA93) and the Balanced Budget Act (BBA) of 1997. ${ }^{13}$ These Acts included expenditure cuts and tax increases, as well as an extension through FY 2002 of existing budget enforcement provisions, including caps on discretionary spending and a pay-as-you-go (PAYGO) requirement under which any legislation that reduced revenues or raised mandatory spending had to specify offsetting measures such that the deficit would not increase. By end FY 1999, federal debt held by the public declined to 40 percent of GDP. The state and local government budget deficit (national accounts basis) remained essentially unchanged in 1999 at about $1 / 2$ percent of GDP. ${ }^{14}$

${ }^{12}$ Fiscal years start on October 1 . The unified federal government balance refers to the combined balances of the federal government ("on-budget") and of the Social Security system and the U.S. Postal Service (the major "off-budget" entities).

${ }^{13}$ An analysis of the breakdown between cyclical and structural contributions to U.S. deficit reduction is provided in "A Postmortem on the Achievement of Federal Fiscal Balance," in United States: Selected Issues, IMF Staff Country Report No. 98/105.

${ }^{14}$ The state and local government balance on a national accounts basis shifted from surpluses reported previously since the late 1960 s to deficits, largely because of a change in the treatment of government pension plans in the 1999 benchmark revision of the national income and product accounts. Government pension income and outlays are now treated as if these plans (which have been running substantial surpluses) are part of the household sector, in the same manner as private pension plans, and their surpluses correspondingly appear as part of household, rather than government finances. 


\section{B. The Outlook}

18. The staff projects a slowdown in real GDP growth to an annual rate of $4 / 4$ percent in the second quarter of 2000, and a further deceleration to around 3 percent in the second half of the year, implying an average growth of 4.9 percent for the year (Table 5). As the impact of the Federal Reserve's past and prospective tightening in monetary policy takes hold, consumption and investment spending are expected to ease A substantially slower rise in household wealth is also expected to reduce consumption growth. After 2000 , the economy would continue to grow at around 3 percent, slightly below potential. Although net exports are projected to be less of a drag on growth in 2000 , the current account deficit is expected to remain roughly at its fourth quarter 1999 level of 41/4 percent of GDP in 2000 and close to this level over the medium term, as some narrowing in the trade deficit owing to relatively stronger growth in the rest of the world is largely offset by a further deterioration in net investment income. The current account projection is based on the standard WEO assumption that the dollar's real effective exchange rate remains constant throughout the forecast period. If this assumption were relaxed, it would be expected that the real effective dollar exchange rate would depreciate and the current account deficit would narrow. Staff estimates suggest that a current account deficit of $1 \frac{1 / 2}{2}$ to 2 percent of GDP would be sustainable over the long term, although such estimates are clearly subject to considerable uncertainty. ${ }^{15}$

\section{The potential for an unexpected increase in inflation presents the principal risk to} the outlook. Despite strong economic growth, inflation has generally remained subdued because of favorable factors that have served to hold inflation down, including weak commodity prices, declining import prices (partly reflecting the strong dollar), and moderate wage gains. Thus far, second-round effects of the rise in oil prices have been limited, as firms have tended to absorb the associated cost increases owing to competitive pressures and strong productivity increases. If instead higher costs are increasingly passed on, there could be sustained upward pressure on core inflation. At the same time, stronger growth in the rest of the world could push up other commodity and non-oil import prices and might exert downward pressure on the U.S. dollar, as some capital flows are seversed. In such an environment, wage demands in the United States could strengthen, especially in the context of continuing tight labor market conditions. Moreover, there is the possibility that growth in domestic demand may not respond sufficiently to the recent tightening in monetary policy and slow by as much as expected, adding to potential inflationary pressures. All of these factors could require a more aggressive tightening of monetary policy. The effects of this tightening on economic activity could be unintentionally magnified if substantially higher interest rates friggered a sharp fall in equity prices.

${ }^{15}$ A detailed discussion on the longer-term sustainability of the U.S. current account deficit is contained in "Long-Term Sustainability of the U.S. Current Account Balance," United States: Selected Issues, IMF Country Report No. 99/101, September 1999. 
20. The possible consequences for economic activity in the United States and the rest of the world should such a situation arise are illustrated by a "harder landing" scenario (derived using Multimod), which was presented is the May 2000 World Economic Outlook. The scenario envisages that in response to faster-than-expected domestic demand growth and consequent rising inflationary pressures, the U.S. monetary authorities raise short-term interest rates during the second half of 2000 by about 100 basis points to a federal funds rate of around $7 \frac{1}{2}$ percent. As a result, a marked ( 25 percent) correction in U.S. equity prices and a depreciation in the dollar (almost 20 percent), following a reversal of capital flows, are assumed to occur. The United States would experience a brief, but sharp slowdown in GDP growth to less than 1 percent in 2001, with growth recovering subsequently and with three-quarters of the loss in output being made up by the end of the forecast period in 2004 (Table 6). Europe and Japan would experience less of a slowdown in growth in 2001 than the United States, and they would recover any output lost by 2004 . One concern, however, is that given the fragility of the Japanese economic recovery at present and the country's limited room for providing the economy further stimulus, Japan might be particularly vulnerable to a slowdown in the United States and a further appreciation of the yen. Among the developing countries, higher world interest rates would negatively affect Latin America in particular, given their sizable foreign currency debt and gross borrowing requirements, while decreased U.S. demand would have significant adverse affects on Latin America and Asia, owing to their economic links with the United States. However, there is substantial scope for discretionary macroeconomic policy actions in the United States to cushion the impact on U.S. activity, a point emphasized by the authorities during the discussions. ${ }^{15}$

\section{Policy Discussions}

21. The following issues were the focus of the consultation discussions:

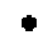

the need for the United States to slow aggregate domestic demand growth to a rate below that of potential supply in order to forestall inflationary pressures. This would also allow the current account to adjust over time;

${ }^{16}$ Although the scenario does not assume specific countercyclical policy measures, some countercyclical actions are built in since the automatic fiscal stabilizers and the normal monetary policy reaction functions in Multimod are allowed to operate. The policy rule embedded in Multimod's monetary policy reaction function for the United States provides for a relatively slow response by the authorities to the decline in economic activity, as shortterm interest rates are not significantly reduced until about two years after the initial interest rate shock. It is likely that the Federal Reserve would move more quickly than Multimod suggests to lower interest rates, especially if there were not a build-up of inflationary expectations to constrain a prompt forward-looking monetary policy response. 
- the need to rebalance global demand by promoting sustained economic expansions in other countries while U.S. domestic demand growth slows in order to mitigate the risk of an abrupt reversal in the large and growing external imbalances among the major economies;

- whether additional monetary policy action is likely to be required to ensure that inflation remains under control;

$\bullet$

whether the accumulation of debt by $U_{+S}$. households and corporations as equity prices have soared suggests there may be significant vulnerabilities to a sudden economic slowdown;

- preservation of the rising fiscal surpluses in prospect in order for fiscal policy to assist in restraining domestic demand growth in the near term and to address the financial needs of Social Security and Medicare in the longer term.

\section{A. Economic Conditions and Prospects}

22. The authorities agreed with the staff on the importance of rebalancing domestic demand growth across the major industrial countries. Over the past several years, strong U.S. growth had supported global economic activity, but continued rapid domestic demand growth in the United States was not sustainable. The U.S. representatives noted that the world economy could not continue to "fly on one engine" indefinitely, with the United States providing the main stimulus to growth. They recognized that demand growth in the United States needed to slow in order to prevent an emergence of inflationary pressures, but they also considered that it was important for demand growth in other major industrial countries to be raised. Although recovery in the rest of the world appeared to be well underway, in their view, a good deal of global excess capacity remained, and greater policy efforts by the other major countries were needed to support recovery in domestic demand in their economies. Such efforts would help to soften the impact on the global economy of the inevitable U.S. slowdown.

23. While the U.S. authorities were of the view that it was not possible to predict confidently when and how the external position and the dollar would adjust, they agreed that the United States could not continue indefinitely running current account deficits in excess of 4 percent of GDP. However, it was not clear that the current situation presented a serious risk. While acknowledging that, given the size of the deficit, there was always the possibility of a sharp adjustment in the event of a sudden reappraisal of international prospects by investors, the authorities pointed out that on previous occasions there had been large, rapid adjustments in the current account balance and the dollar without these adjustments having major adverse consequences. Moreover, they were of the view that gradual adjustments over extended periods of time were more common. They also emphasized that the exchange value of the dollar was not the only variable that would serve to bring about adjustment in the U.S. curtent account balance. When it came, adjustment in the deficit would be brought about by changes in relative income growth and wealth, and 
changes in the relative prices of tradable goods associated with movements in both nominal exchange rates and relative inflation rates.

24. The staff suggested that raising national saving by maintaining the prospective fiscal surpluses could help to alleviate the burden of adjustment that otherwise would be placed largely on the exchange rate. The orderliness of the current-account adjustment process, although by no means guaranteed, would likely be facilitated if the sizable U.S. fiscal surpluses in prospect were allowed to materialize. Although the U.S. representatives acknowledged that this might help, they also noted that it was difficult to predict how markets might react in such circumstances. It was possible, for example, that further fiscal consolidation, by strengthening the overall U.S. business environment, could stimulate a sufficiently forceful investment response to more than offset the improvement in government saving. The associated further gains in confidence could trigger even stronger capital inflows, leading to the dollar strengthening in the near term.

\section{While it was agreed that national savings was crucial in determining the levels of} gross domestic and net foreign investment in the economy, the authorities were asked whether the negative private saving-investment balance raised the risk of an abrupt reversal, which could present challenges for demand management policies, and whether such an imbalance might foreshadow balance sheet problems in the event of a major economic downturn. The authorities noted that the low personal saving rate and the rising current account deficit were fundamentally related to the surge in productivity growth in recent years, which has enhanced corporate profitability and contributed to the sharp nun-up in stock prices. The authorities said that, in their view, the private saving-investment imbalance did not present an independent risk to the U.S. outlook, whether through possible problems in household or corporate balance sheets or a significant possibility of overinvestment (Box 5). In the event of a sharp economic downturn, some isolated balance sheet difficulties inevitably would arise (Box 6). The substantial increase in household debt, for example, was not likely by itself to trigger an economic downturn, but some problems could emerge in the event of a major slowdown. Ex post, evidence of poor investment choices would likely also emerge in some sectors. However, in their view, the United States at this point did not appear to be suffering the same kind of pervasive asset inflation or overinvestment that Japan experienced in the late 1980s (Box 7).

26. The decline in personal saving to historically very low rates was associated in the more recent past with the rise in household wealth, and the authorities and the staff agreed that the personal savings rate would rise when wealth effects diminished Nevertheless, private saving was seen as holding down national savings to a level that the authorities considered to be too low. Increasing national savings was viewed by the authorities as being particularly important to extend the current investment-led economic expansion and to take full advantage of the increased returns to investment which appeared to be available at present. Since inducements to personal saving in the past largely benefited higher income individuals and generally had proven to be ineffective, the Administration sought to boost personal savings through a variety of schemes, including targeted income tax incentives to promote savings by low and middle income households. The effectiveness of these schemes 


\section{Box 5. Private Sector Saving-Investment Balances}

The U.S. privatc sector saving-investment balance has deterioratod during the current expansion, with a deficit emerging in 1997 and widening to nearly 3 percent of GDP by 1999 . Some concerns have been raised that the decline in net private saving may prove to be unsustainable based on experience in several other advanced economies in recent decades, but in a number of respects the recent U.S. experience differs from these other cascs.

In common with the other cases, the recent decline in U.S. private net saving was driven by a decline in saving and a rise in investment (see table). However, the recent U.S. experience differs in ferms of the composition of the investment build-up. In previous experiences, the rise in private investment reflected substantial increases in cornstruction investment related to booms in real-estate markets. In the U.S. experience during the 1990 s, most of the rise in private investment has been in equipment, which has been a key factor behind the strong productivity gains in recent years. Construction investment has played only a snall role in the rise in private iovestment, and there has been no evidence of a generalized real-estate boom.

The excesses in construction during the build-up in previous episodes were reversed during the subsequent adjustment and contributed to sharp declines in investment (see chart below).

The predominance of equipment investment in the recent rise in U.S. private investment is also an important difference from most earlier experience. To the extent that there could be some over-investment, although the initial effects of a corroction may be substantial, the increasing role of computer-related capital (which has a relatively rapid rate of depreciation) in equipment investment suggests that such effects may not have a prolonged impact.

Private Sector Saving and Investment

Cumulative Change from Start of Period (in percent of GDP)

\begin{tabular}{|c|c|c|c|c|c|}
\hline & Net Saving & Saving & Investment & $\begin{array}{l}\text { Equipment } \\
\text { lnvestment }\end{array}$ & $\begin{array}{l}\text { Construction } \\
\text { Investment }\end{array}$ \\
\hline U.S. (1992-99) & -7.8 & -3.6 & 4.2 & 2.5 & 1.1 \\
\hline U.S. $(1976-79)$ & 4.5 & -0.8 & 3.8 & 1.6 & 2.4 \\
\hline Canada (1985-1989) & -5.9 & -3.1 & 2.8 & 1.1 & 1.9 \\
\hline $\operatorname{Japan}(1987-1990)$ & -8.8 & -4.2 & 4.6 & 2.5 & 2.0 \\
\hline U.K. (1985-1989) & -9.0 & -4.3 & 4.7 & 1.8 & 2.8 \\
\hline
\end{tabular}
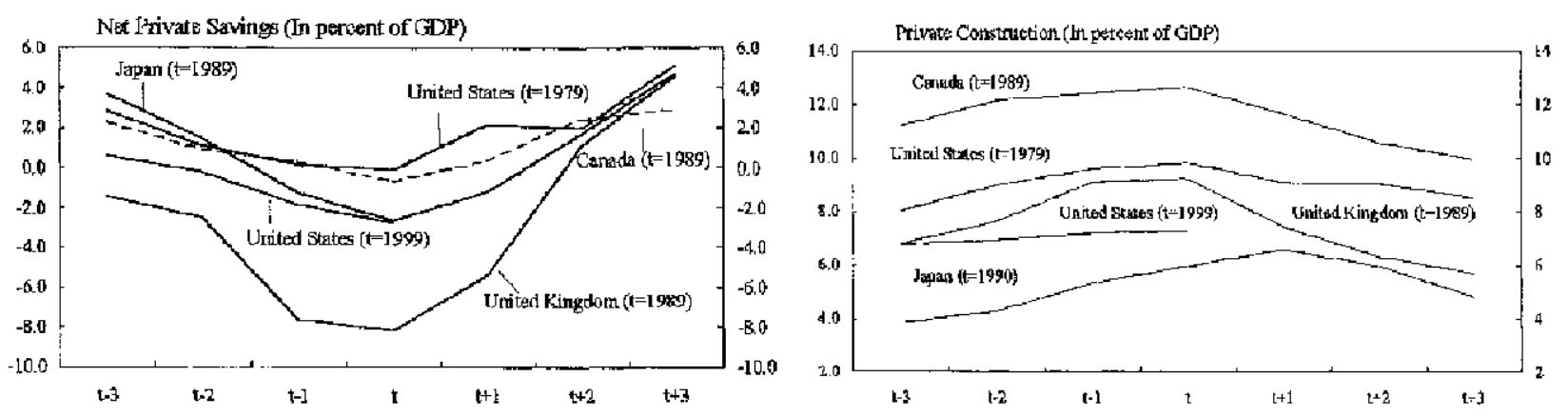

Note: $t$ refers to the trough in net private savings.

Sources: Staff calculations based on the World Economic Ouflook database; and national source dala. 


\section{Box 6. Household and Corporate Balance Sheets}

The sustained boom in consumption and investment continues to affect the composition of household and corpotate balance sheets, with houschold and corporate gross debt-to-income ratios at, or close to, their historical pcaks. However, household net worth has risen even mote rapidly and the ratio of corporate debt-to-equity has declined. Although these indicators do not suggest any significant problems at this time, the high levels of debt may present difficulties in the cvent of a major economic downturn.

Household sector

After remaining essentially stable in 1990-94, household debt as a share of disposable income rose to 103 percent (a record level) by 1999 (tabulation below). An increase in mortgage debt, reflecting heavy refinancing at lower interest rates prior to 1999 and a further rise in residential investment, was the largest contributing factor.

At about $13 \frac{1}{2}$ percent of disposable income in the thind quarter of 1999 , the debt-service burden of the household scetor is estimated to have reached its highest level since the late $1980 \mathrm{~s}$; nevertheless, the level of debt ser vice has not risen significantly since 1997. The limited rise in the debt-service ratio is largely attributable to the surge in mortgage refinancing at lower interest gates. Becausc only about 15 percent of outstanding mortgages have adjustable rates, the shift to mortgage refinancing has reduced the overall vulnerability to a rise in interest rates.

Largely reflecting the continued rise in equity markets, household net worth as a share of disposable personal income rose from aboul 481 percent in 1994 to 633 percent in 1999. A 46 percent drop in equity prices would be needed to retum the priceleamings ratio of the S\&P 500 to the historical average for the period 1950-94 (exeluding the high-inflation period in the 1970s), and would cause household net worth to fall to roughly 556 percent of disposable income (the level in 1997).

\section{Corporate sector}

The ratio of corporate debt to equity is estimated to have fallen for the fifth consecutive year in 1999, (figure below), largely as a result of increasing equity prices. A 46 percent drop in equity prices wauld cause the debt-to-equity ratio to rise to just 55 percent roughly the level prevailing in 1992 and well below the levels prevailing throughout the 1980 s.

Although 1999 marked the eighth year of growth in corporate earnings, the ratio of corporate debt to income rose for the third consecutive year (to 341 percent), but remains below the levels that prevailed from the mid-1980s-1992.

Corporate debt service (measured as the ratio of net interest payments to cash flow) in 1999 remained at the low levels prevailing aver the last several years.

Default rates on jurk bonds rose in 1999, reaching the level prevailing during the last recession, while Moody's Investor Services downgraded more nonfinancial debt issuers than it upgraded.

Balance Shecl of Houscholds

(In percent of disposable income)

\begin{tabular}{lrr}
\hline & 1990 & 1999 \\
\hline Total assets & 566 & 736 \\
Tangible & 217 & 210 \\
Financial & 349 & 526 \\
(of which equities) & 57 & 169 \\
& & \\
Total liabilities & 86 & 103 \\
Mortgages & 57 & 67 \\
Consumer credit & 20 & 21 \\
Net worth & 480 & 633 \\
\hline
\end{tabular}

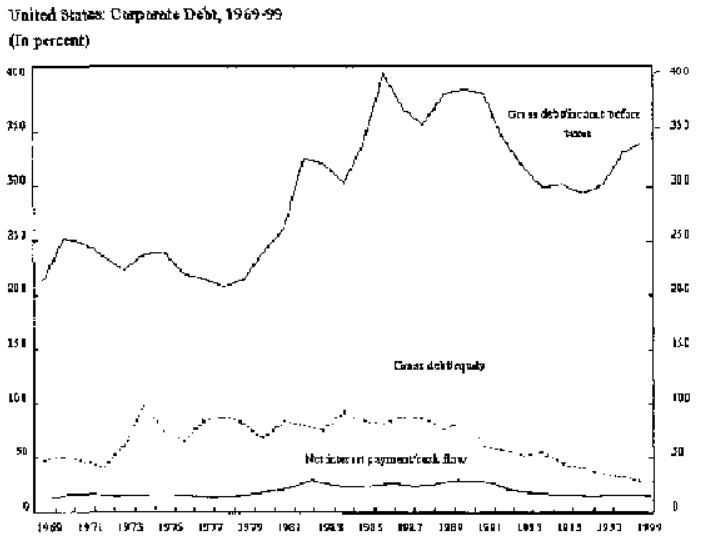

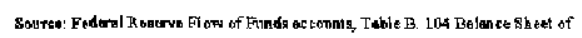

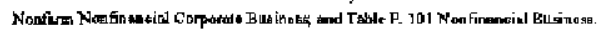




\section{Box 7. A Comparison of Japan in 1985-90 and the United States in 1994-99 1/}

Strong economic growth and high equity prices in the United States over the past five years have prompted considerable speculation as to whether U.S. developments were being driven by an asset price bubble similar to that experienced by Japan in the late 1980s. While the "bubble economy" period in Japan shares some similar features with the current expansion in the United States, and was also attributed at the time to the adoption of new technologies, there are important differences.

Although both countries experienced significant gains in equity prices and labor productivity, growth in corporate profits was relatively weak in Japan but has been strong in the United States. In Japan, the P/E ratio peaked at almost twice its long-run average in 1988, and was still roughly 50 percent above its 1985 level after equity prices declined in early 1990. In the United States, the P/E ratio in 1999 was also almost twice its long-run average. However, the share of corporate profits in national income grew only modestly in Japan; in the United States, it has risen significantly since 1994, and was 15 percent higher by end-1999.

The rise in asset prices appears to have been more widespread in Japan, with land prices almost three times higher in 1990 than in 1985. The boom in land prices was accompanied by a marked rise in bank and non-bank lending to the real estate sector. The share of lending to the real estate sector by banks and the Housing Mortgage Association was 15 percent higher by 1990 than in 1985. In contrast, real estate prices in the United Stales have risen only modestly in real terms, and have not been accompanied by a marked increase in bank lending to the reat estate sector.

Even though higher asset prices stimulated business investment in both economies, there are significant differences in the composition of investment. The process of "capital deepening" in the United States las been reflected in investment being concentrated in machinery and equipment. The share of investment in construction to GDP has remained flat in real terms sinco 1994. In contrast, the investment boom in Japan was led by increases in both machinery and equipment and construction.

\begin{tabular}{|c|c|c|c|c|c|c|}
\hline & $t-5$ & $\mathrm{t}-4$ & $\mathbf{t}-\mathbf{3}$ & $t-2$ & $t-1$ & $\mathrm{t}$ \\
\hline \multicolumn{7}{|l|}{ Price-earnings ratlo 21} \\
\hline Japan & 82.6 & 106.1 & 187.5 & $1 \$ 4.1$ & 141.1 & 127.5 \\
\hline United States & 105.5 & 96.4 & 112.6 & 129.9 & 168.9 & 186.2 \\
\hline \multicolumn{7}{|c|}{ Corporate profits (in percent of national income) } \\
\hline Japan (national entrepreneurial income) & 100.0 & 101.0 & 104.3 & 108.8 & 104.1 & 93.5 \\
\hline United States & 100.0 & 110.3 & 117.7 & 122.5 & 116.8 & 115.4 \\
\hline \multicolumn{7}{|l|}{ Land prices } \\
\hline Japan & 100.0 & 109.7 & 139.2 & 171.6 & 197.6 & 263.2 \\
\hline United States & 100.0 & 102.3 & 104.7 & 107.8 & 110.8 & 116.4 \\
\hline \multicolumn{7}{|l|}{ Share of barkl lending to real estate } \\
\hline Japan & 100.0 & 107.8 & 109.2 & 112.8 & 115.6 & 114,9 \\
\hline United States & 100.0 & 100.4 & 100.0 & 99.6 & 99.2 & 105.6 \\
\hline \multicolumn{7}{|l|}{ Labor productivity in manufacturing } \\
\hline Japan & 100.0 & 100.0 & 104.2 & 111.9 & 116.9 & 120.2 \\
\hline United States & 100.0 & 103.9 & 108.1 & 113.5 & 118.9 & 126.5 \\
\hline \multicolumn{7}{|l|}{ Composition of business investment } \\
\hline \multicolumn{7}{|l|}{ Machinery and equipment } \\
\hline Japan & 100.0 & 100.5 & 104.7 & 114.1 & 121.9 & 127.9 \\
\hline United States & 100.0 & 107.2 & 114.2 & 120.7 & $133+0$ & 141.8 \\
\hline \multicolumn{7}{|l|}{ Construction } \\
\hline Japan & 100.0 & 102.4 & 102.6 & 104.9 & 113.3 & 117.8 \\
\hline United States & 100.0 & 97.8 & 100.0 & 100.2 & 101.3 & 100.6 \\
\hline
\end{tabular}

Source: Staff estimates based on national authorities' sources.

1/ Figures for Japan are based on $1985=100$ and $t=1990$. For the United States, they are based on $1994=100$ and $\mathrm{t}=1999$.

$2 /$ In percent of long-term average. 
in the staff's view was uncertain, depending on the extent to which individuals in the targeted income groups would take advantage of the incentives and whether "new" saving would be generated, instead of a reshuffling of existing saving.

27. With the negative personal saving-investment balance and the current account deficit largely reflecting the level of the stock market, the authorities considered that the susceptibility of these imbalances to sharp reversals hinged on whether current equity valuations were sustainable--a view shared by the staff. Several years of robust productivity growth had clearly helped to increase expectations of long-term corporate earnings growth, and such optimistic expectations would need to be validated in order to sustain the current high market valuations. ${ }^{17}$ Although understanding the factors underlying the surge in productivity growth, and thus the outlook for corporate earnings and the sustainability of high stock market valuations, was a matter of ongoing reassessment, capital deepening and the diffusion of information technologies appeared to be supporting much of the increase. ${ }^{18}$ The improved outlook for productivity growth had raised the authorities" estimates of potential GDP growth for the near term to $3 \frac{1}{2}-4$ percent, although these estimates remained subject to a high degree of uncertainty, and it was difficult to predict how long the higher rate might be sustained. While they were not necessarily proponents of a "new economy" in the United States - in the sense that a permanently higher level of productivity growth was now in place- the authorities believed that considerable opportunities remained for further gains in total factor productivity and in capital deepening. The staff expressed the view that the substantial increase in productivity associated with information technology (IT) investment in recent years was likely to reflect a transition to a higher level of productivity, and not a permanent increase in its growth rate.

28. The authorities noted that some degree of overinvestment was not unusual late in an expansion, but that the evidence of capital deepening, particularly in the area of information technology and the high rates of labor productivity growth, both in the ITproducing sectors and IT-using sectors, did not suggest that any significant misallocation of capital was underway. Indeed, they indicated that many industries had invested with restraint during the current expansion, having experienced the costs of overinvestment in the last economic downturn. Officials noted that many firms surveyed by the Federal Reserve had expressed the view that their capacity to deploy emerging IT technologies productively had just begun, and more generally, there appeared to be considerable room for further diffusion of IT throughout the economy. The staff and the authorities agreed that, even if it

${ }^{17}$ A selected issues paper will investigate the recent trends in equity prices, and the implications for real earnings growth and risk premia.

${ }^{18}$ A selected issues paper will consider the extent to which information technology has contributed to the pick up in productivity growth. Several recent studies conclude that both the production and use of information technology have made significant contributions to productivity growth. 
turned out ex post that a significant degree of overinvestment had taken place, IT investments tended to depreciate rapidly, which would suggest that any resulting "investment overhang" would tend to dissipate more quickly.

\section{The authorities noted that indicators of the financial health of banks were} generally favorable-as was to be expected given the strength and duration of the current expansion--but agreed that there were a number of isolated warning signs that warranted attention (Box 8). The authorities were well aware that most loans that tumed out to be "bad" loans were made in the later stages of an economic expansion; in the event of a significant economic downturn, such loans inevitably would be exposed, with consequences for bank profitability. Overall, however, the U.S. banking system appeared well-prepared to cope with such a contingency. In particular, bank profits had been high and rising in recent years, banks were well-capitalized, and most had implemented better risk management systems. However, there were indications that some banks' credit decisions had been based on an extrapolation of the current benign economic conditions, which could well prove to be unrealistic. To counter this tendency, the authorities have made public statements and issued supervisory guidance letters formally cautioning the banks against being unduly reliant on optimistic assessments of futute financial performance in making their lending decisions. The staff strongly supported these actions. The last two surveys of senior loan officers have indicated that banks are being increasingly cautious in their lending to commercial borrowers, which the authorities attributed to "jawboning" from federal regulators and self-initiated risk-control initiatives by the banks.

\section{B. Monetary Policy and the Exchange Rate}

30. In response to the rapid pace of economic activity and increased indications of wage and price pressures, the monetary anthorities have significantly tightened monetary policy over the past year. The Federal Reserve officials noted that the economy retained considerable momentum and that there was only limited evidence at the time of the discussions that it was cooling off. The staff agreed that an unusual degree of uncertainty surrounded estimates of potential GDP and the natural rate of unemployment, making these indicators less useful as guides to policy. However, after a period of unusual wage restraint, tight labor markets were beginning to produce some signs of rising wage pressures (see Figure 13). They agreed with the staff that factors which have helped to contain inflation over the past few years (e.g., declining health care costs and import and commodity prices) and contributed to a virtuous price/wage cycle, may begin to reverse. In these circumstances, the staff noted that a further near-term tightening of monetary policy would likely be needed.

\section{Although monetary policy actions up to the time of the discussions dial not appear} to have had substantial restraining effects on domestic demand growth, the Federal Reserve officials did not see this development as reflecting any fundamental changes in the transmission mechanism for monetary policy. They suggested that special factors rather than systemic changes in policy transmission channels probably accounted for a somewhat weaker-than-expected demand response to the monetary tightening begun in 1999 . In particular, the intended effects of the tightening may have been partially offset by the sharply 


\section{Box 8. Recent Indicators of the Quality of Bank Credit and Banking Sector Vulnerabilities}

On balance indicators of bank credit quality and banking sector vulnerabilities do not raise significant concems, but there are some isolated waming signs and more significant problems could emerge in the event of a major downturn.

The asset composition of commercial banks has changed over the past two decades, with the share of mortgages and U.S. government securities rising relative to commercial and consumer loans. However, the reduced share of commercial loans is roughly offset by the rise in bank holdings of corporate and forcign bonds, suggesting that the total exposure to businesses is about unchanged. The share of real estate loans has not changed since 1990, while consumer credits have fallen.

At just over 2 percent, the share of delinquent loans at end-1999 was essentially unchanged from a year eartier (see figure). Delinquency rates on residential real estate loans fell in 1999, contimuing a long downward trend, while delinquency rates on commercial and industrial loans rose. Deiinquencies for credit card and consumer loans have remained high, but essentially flat for the past several years. At 0.61 percent in 1999, charge-off rates at insured commercial banks were broadly unchanged over the last two years, and were approximately 1 percentage point lower than the most recent peak in 1991 .

The Federal Reserve's quarterly survey of bank lending practices indicates that banks became somewhat more cautious lenders in the final quarter of 1999 and the first quarter of 2000 (see figure). This tightening of loan standards may have been in response to a Federal Reserve supervisory guidance letter issued in September 1999, citing evidence that banks in some cases had relaxed their credit discipline in the area of commercial loans. The letter emphasized the importance of stress testing and cautioned that loans shonld not be made on the basis of "undue reliance on continued favorable economic conditions."

The premium demanded on bank subordinated debt relative to U.S. Treasury bonds rose sharply in 1998 following the Russian default (see figure). Although the yicld spread declined as financial markets steadied toward the end of 1998, it remains above its pre-crisis level. It is not clear whether this reflects a downgraded assessment of the quality of bank credit, or whether it reflects changing market prefcrences for riskier assets. Profits in the banking industry rose by 16 percent in 1999, the eighth consecutive year of record annual profits. Although bank and thrift failures
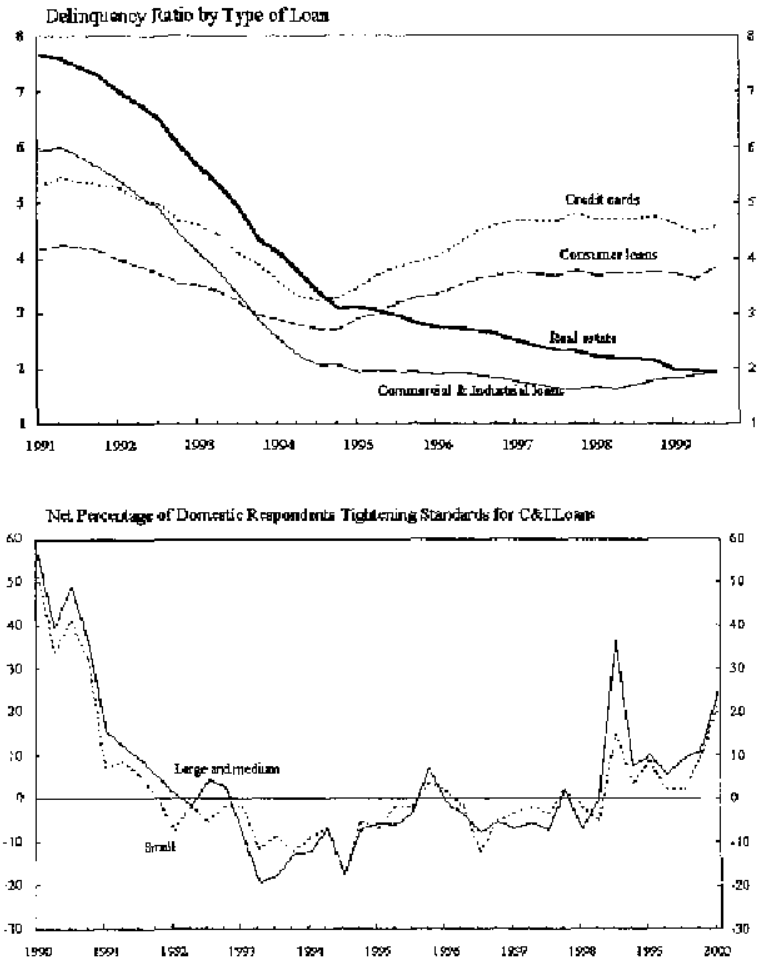

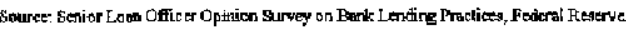
increased from 3 in 1998 to 8 in 1999, this remained very low by the standards of the 1980s and early 1990 s. 
appreciating stock market, as strong expectations for corporate earnings growth apparently outweighed the effects of higher interest rates. It was also possible that returns on investment had risen, as evidenced by an increase in long-term real interest rates, which would imply stronger investment demand at any given interest rate than otherwise. Moreover, monetary policy operates with a lag, and the effects on demand growth of the tightening of policy that has taken place over the last year were expected to become stronger in the period ahead.

32. Federal Reserve officials reiterated that in formulating monetary policy they sought to achieve high levels of employment, maximum sustainable growth, and low inflation. Despite the role played by rising stock market wealth in fueling domestic demand growth, the level of stock prices (and asset prices more generally) should not, in their view, be a target for monetary policy. Identifying the fundamental equilibrium level of asset prices was not something that could be done with any degree of confidence, and asset price bubbles were easier to identify ex post than ex ante. In addition, even if central bankers believed an asset bubble existed, there was little reason to believe that monetary policy could gently deflate the bubble. The staff agreed that targeting a particular level of asset prices should not be a goal of monetary policy, since it was very unlikely that the "right" price could be identified. Nevertheless, information provided by asset prices could still have a role to play in macroeconomic policy formulation, especially in circumstances where optimism about future productivity and earnings growth was boosting aggregate demand more than supply in the short run.

\section{With the goal of improving transparency, the FOMC began announcing in} May 1999 its policy decisions and the official intermeeting "policy bias" immediately after its regular meetings. The officials noted that, because the new practice had caused unanticipated confusion among market participants, procedures were revised in January 2000 . Under the new procedure, a statement regarding the Committee's sense of the "balance of inflation risks" is released at the conclusion of regular meetings. So far, this approach appeared to have successfully avoided the misinterpretations that seemed to plague the previous announcements of the policy bias, and officials believed it had contributed to enhancing transparency.

\section{Federal Reserve officials indicated that spillover effects from $U . S$. actions on other} countries were taken into account in the formulation of U.S. monetary policy only to the extent that these effects had implications for U.S. economic prospects. Moreover, officials believed that recent actions to tighten monetary policy in small, well-anticipated steps reduced the negative effects that such actions might have on the rest of the world. Provided other countries pursued appropriate policies, efforts to gradually rein in demand growth in the United States should not pose substantial difficulties for other countries. The staff agreed that the maintenance of sustainable, noninflationary growth in the United States was an important precondition for ensuring a stable global economic environment. The staff supported the authorities' incrementaI approach, citing research which suggests that sharp 
and abrupt changes in the stance of U.S. monetary policy could significantly raise sovereign spreads and disnupt economic activity in some emerging market countries. ${ }^{19}$

\section{The authorities suggested that the performance of the U.S. economy was probably} the main factor contributing to the strength of the dollar. The surge in productivity growth has boosted the rate of return to capital and has attracted substantial capital inflows, helping sustain the large current account deficit and the dollar's high value. While significant revisions to the prospects for sustained productivity growth could lead to a sharp adjustment in the value of the dollar, the authorities saw a gradual adjustment over time as more likely, if sound macroeconomic policies were maintained in the United States. Over the past year, movements in bilateral exchange rates had at times generated calls for coordinated intervention. The authorities indicated that they had refrained from engaging in such activities because of the difficulty in assessing whether exchange rates have moved substantially out of line with underlying economic fundamentals and the limited effectiveness of sterilized intervention.

\section{Fiscal Policy}

\section{The Administration's FY 2001 Budget envisages a further strengthening of the} fiscal position over the medium term. The current services baseline projects continued surpluses, rising from $\$ 171$ billion (1.7 percent of GDP) in FY 2001 to $\$ 247$ billion (2,0 percent of GDP) in FY 2005 (Table 7). ${ }^{20}$ In the Administration's Budget, the proposed fiscal measures are estimated to reduce the projected surpluses over the period FY 20012005 by $\$ 57$ billion, with surpluses remaining around 13/4 percent of GDP through FY 2005. In the Mid-Session Review of the FY 2001 Budget released in late June, the current services surplus is projected to rise from $\$ 239$ billion (2.3 percent of GDP) in FY 2001 to $\$ 360$ billion (2.9 percent of GDP) in FY 2005 (Table 8). The sharply higher projected surpluses reflect revisions to the economic assumptions, particularly an upward revision in real GDP. Including new measures proposed in the Mid-Session Review, total proposed measures are estimated to reduce projected surpluses by $\$ 287$ billion over FY 2001-05. The new measures include a proposed Reserve for America's Future that would earmark $\$ 500$ billion of

${ }^{19}$ The forthcoming selected issues paper will anaiyze the role of U.S. monetary policy in influencing sovereign bond spreads in developing countries. Staff estimates suggest that an increase in the target federal funds rate tends to widen spreads on emerging market debt and that increased interest rate volatility, which reflects heightened uncertainty about the expected path of U.S. monetary policy, also tends to significantly raise spreads.

${ }^{20}$ The current services baseline represents the Administration's projections for government revenue and expenditure in the absence of new policy actions. Adjusting for differences between the staff's and the Administration's macroeconomic assumptions, the staff projects larger medium-term surpluses, owing to the staff's higher assumptions for real and nominal GDP growth that are only partly offset by the staff's higher assumptions for interest rates. 
projected on-budget surpluses over the next ten years to be used for key priorities, such as retirement saving, targeted tax cuts, health care and education. In addition, the Administration proposes a substantially more generous new Medicare prescription drug benefit.

37. The fiscal measures proposed in the February Budget and the Mid-Session Review focus on the Administration's key medium-term priorities of reducing the public debt, while also providing targeted middle-class tax cuts, improving the quality of health care, and strengthening the longer-term finances of the Social Security and Medicare programs. The budget proposals also include higher spending and tax incentives for education and training and higher spending on national defense.

38. Administration officials emphasized that they intended to substantially preserve the fiscal surpluses in prospect, which would help in the near term to contain demand pressures and, in the longer term, to prepare the federal government for the future costs associated with the aging of the population. The staff endorsed this approach and observed that a tightening of the fiscal position would also reduce the burden on monetary policy, and thereby lessen potential upward pressure on the value of the dollar and a widening in world current account imbalances. In this context, the Mid-Session Review projection for a budget surplus in FY 2000 of $\$ 224$ billion ( $2 \% / 4$ percent of GDP) would entail a withdrawal of fiscal stimulus of around $3 / 4$ percent of GDP.

\section{Important differences remained between Congress and the Administration on the} FY 2001 budget. The budget resolution passed by the Congress differs significantly from the Administration's budget, in that it proposes large tax cuts and specifies substantially lower levels of discretionary spending. ${ }^{21}$ In view of the compression in real discretionary spending that has occurred in recent years, the U.S. representatives did not consider such spending restraint viable, and thus, they opposed tax cuts of the size proposed in the Congress's budget resolution.

40. The staff strongly endorsed the Administration's proposal to extend the discretionary spending caps and the PAYGO financing requirement through FY 2010. The staff and the authorities agreed that these budget enforcement provisions, which are set to lapse after FY 2002, have made a significant contribution to the improvement of the fiscal position since FY 1992. The staff also considered it appropriate, in line with the Administration's proposal, to adjust the caps upward to reflect currently enacted levels of discretionary spending and to adjust these spending caps roughly in line with inflation thereafter. However, the staff emphasized that once the caps were modified, adherence to the caps and PAYGO should be firmly re-established.

${ }^{21}$ The Administration's Budget envisages net tax cuts of $\$ 55$ billion during 2001-05, and of $\$ 256$ billion during 2001-10, while Congress's budget resolution envisages cuts of $\$ 150$ billion during 2001-05. 
41. As in past years, the Administration's FY 2001 Budget includes a number of targeted tax credits intended to promote specific economic or social objectives. ${ }^{22}$ The staff continued to take the view that such incentives undermine the simpliffcation of the income tax code achieved by the 1986 tax reforms, thereby raising compliance costs. Targeted tax incentives also tended to erode the tax base and thus ultimately required higher statutory tax rates than otherwise, consequently reducing the overall efficiency of the tax system. The staff considered that most of the Administration's underlying objectives could be addressed effectively through direct spending measures. Administration officials responded that the proposed tax incentives were not large enough to cause major tax distortions. Moreover, they maintained that tax incentives would avoid the administrative costs associated with new spending programs, and could effectively use the administrative infrastructure of the tax system to ensure that only the targeted income groups received the new benefits.

\section{The Administration has expressed the view that there are compelling reasons for} pursuing as a medium-term goal the elimination of the net federal debt held by the public. The Administration's Mid-Session Review of the FY 2001 Budget envisages that this debt would be eliminated by 2012 . Eliminating the public debt was considered important as a means of preparing for the coming costs associated with an aging population, but the U.S. representatives also emphasized that it was especially critical to run large surpluses (and thereby support a high level of national saving) in order to expand the resources available for the private sector to invest at a time when productive opportunities appeared to be plentiful. By enabling greater investment in the private economy, the growth rate of potential output could be maintained at a high level. In addition, by retaining large surpluses the external current account deficit could be reduced without having to reduce private investment.

43. The staff strongly supported the Adninistration's intention to eliminate the public debt over the medium term, and the authorities acknowledged that the overall fiscal position may need to remain in surplus after the net public debt has been retired, in order to deal with the longer-term imbalances facing Social Security and Medicare. The staff indicated that a reasonable long-term fiscal objective might be to adopt measures to eliminate the actuarial imbalances in Social Security and Medicare Hospital Insurance (HI), while attempting to keep the remainder of the budget roughly in balance on average over the business cycle. In order to ease pressures to divert surpluses in Social Security and Medicare $\mathrm{HI}$ to other uses, the staff suggested that it might be useful to more formally separate the revenues and expenditures of these two programs from the rest of the federal budget.

\footnotetext{
${ }^{22}$ Targeted tax cuts include measures to expand educational opportunities (including through a lifetime learning tax credit for post-secondary education and tax incentives for publicschool construction and modernization), to make health care more affordable (including through a tax credit for the Medicare buy-in proposal and tax relief for workers with disabilities), and to expand retirement savings and portability through new retirement savings accounts.
} 
44. The authorities emphasized that, by agreeing to keep Social Security surpluses "off-limits"-the so called "lockbox" approach-the Administration and Congress had indeed shifted the focus to the "on-budget" balance in making their policy proposals. Moreover, in the Mid-Session Review of the FY 2001 Budget, issued after the conclusion of the discussions, the Administration proposed a similar lockbox approach to take Medicare $\mathrm{Hl}$ off-budget. The authorities considered that this approach would help maintain a major portion of the unified budget surpluses in prospect over the medium term, and thereby, ensure that a substantial portion of the future obligations of these programs were "prefunded". The authorities also thought that part of these obligations might usefully be prefunded by transferring on-budget resources to Social Security and Medicare, precluding the use of these resources for other near-term purposes, such as tax cuts or spending increases. To this end, the FY 2001 Budget had proposed the transfer of part of the interest savings from retiring the public debt from the on-budget account to the Social Security trust funds over the period FY 2011-50. ${ }^{23}$ The Administration also proposed to allow half of these transfers to be invested in corporate equities, further extending the life of the trust funds owing to higher expected returns. ${ }^{24}$ The authorities questioned the staff's suggested long-term fiscal objective, expressing concern that it might entail further increases in projected budget surpluses, which were already substantial. However, actions proposed by the staff to address the actuarial imbalances in Social Security and Medicare could be adopted without increasing unified federal budget surpluses above their current services estimates.

\section{The staff suggested that the Administration's proposal to make transfers from} general budget resources to Social Security raised a number of issues that might be awided by working within the existing structure of the system. The staff noted that the long-term financing needs of Social Security could be addressed by relatively small adjustments in the system's parameters. ${ }^{25}$ Specifically, a combination of small payroll tax increases and/or benefit changes (including through a further increase in the retirement age) equivalent to about 1.9 percent of taxable payroll would be sufficient to restore long-term actuarial balance ${ }^{26}$ By maintaining the exclusive reliance on the Social Security payroll tax

These transfers would rise from $\$ 100$ billion in 2011 to more than $\$ 200$ billion annually after 2015.

${ }^{24}$ The total share of equity investments in the trust funds would be limited to 15 percent.

${ }^{25}$ The Social Security Board of Trustees defines the system as being in long-term actuarial balance if the present value of projected Social Security receipts is at least as large as the present value of projected outlays over the next 75 years. In the 2000 Reports of the Social Security Trustees and of the Medicare Trustees, the Social Security trust funds were projected to remain solvent until 2037. The Administration's FY 2001 Budget proposes measures to extend the solvency of Social Security by 20 years.

${ }^{26}$ In 2000 , both the employer and the employee pay a Social Security payroll tax of 6.2 percent of gross yearly wages up to a ceiling of $\$ 76,200$. 
to fund the system, the staff noted that the long-standing budget constraint that had helped over the years to counter pressures to raise the level of real benefits would be preserved. The staff was concerned that once the precedent was set to shore up the Social Security accounts through recourse to general budget resources, it might become easier to justify further transfers to finance extensions of benefits. The authorities did not see this as a major risk since their proposed transfers were closely linked to part of the interest savings from retiring the public debt. In their view, the retirement of the baby-boom generation represents a onetime demographic episode that was best addressed through recourse to general revenues, and could be justified on the grounds that it was offsetting the initial costs of payments to early beneficiaries when the system was first established. The staff also suggested that reliance on the payroll tax might be a more efficient means of financing the system, since payroll taxes with a perceived "tax benefit" linkage tend to be less distortionary than comparable income taxes. The authorities considered that using general budget resources, and hence in effect the progressive income tax, to address the funding shortfall would serve an important equity consideration. Moreover, given indications that higher potential growth and reductions in the government's interest burden were significantly improving fiscal prospects, they did not see an apparent need to reduce Social Security benefits.

\section{The Administration also proposes a number of measures to extend the solvency and} broaden the coverage of Medicare. It proposes to devote a portion of on-budget surpluses associated with interest savings from debt reduction during FY 2001-10 to extend the solvency of Medicare HI by an estimated ten years, and would take steps to reduce costs by strengthening competition. ${ }^{27}$ It also proposes a number of new benefits, including a prescription drug plan and a Medicare buy-in option for 55-64 year olds. The staff welcomed the Administration's initiative to strengthen the long-term finances of Medicare HI, but suggested that a preferred approach would be to address the financial shortfall through small changes in the program's parameters, rather than resort to on-budget resources. ${ }^{28}$ Periodic reviews of the program would also be needed given the difficulties in projecting medical costs. The staff also considered that a preferred approach would be to fully address Medicare's longer-term financial imbalance before seeking to introduce new benefits.

\section{With sustained fiscal surpluses in prospect over the medium term, the authorities} identified their main goals for government debt management as achieving the lowest financing costs and promoting efficient capital markets. With debt being retired, they had

${ }^{27}$ In the 2000 Reports of the Medicare Trustees, the Hospital Insurance trust fund was projected to remain solvent until 2023.

${ }^{28}$ Such changes could include small increases in the payroll tax rate, an increase in copayments and deductibles, and/or an increase in the age of eligibility. The 2000 Report of the Medicare Trustees estimated that, under current policies, measures equivalent to about $1 \% / 4$ percent of taxable payroll would be enough to restore long-term actuarial balance to the system. 
reduced the range of maturities in which debt was issued and reduced the size and frequency of issues in order to maintain liquidity in those maturities that the financial markets felt were most important. Although there was no specific target for the average maturity of the debt outstanding (currently about $5 \frac{1}{2}$ years), they sought to prevent it from lengthening. The inversion of the yield curve largely reflected the rise in short-term interest rates and strong fiscal policy, although the representatives acknowledged that the Treasury's buyback operations may have introduced some "scarcity" values at the long end of the maturity spectrum. They pointed out that the shape of the yield curve did not affect their decisions on the structure of debt issuance or debt retirement. The staff asked whether there was any concern about the prospective loss of a risk-free benchmark as government debt was retired. The U.S. authorities responded that they believed strongly that the markets would fill any perceived need for a new benchmark. While having a government securities market might be beneficial, they were not sure that the benefits of preserving such a market in an era of substantial surpluses would outweigh the costs, and minimizing the cost to the taxpayer of financing government operations was seen as an overriding goal.

\section{Other Issues}

48. The Gramm-Leach-Bliley Act (GLB) Act signed into law in November 1999 finally legislated a comprehensive overhaul of the laws regulating the financial sector in the United States. ${ }^{29}$ In particular, the Act repealed the restrictions imposed by the Great Depression-era Glass-Steagall Act, which blocked affiliation between banks, securities firms, insurance companies, and other financial service providers. Financial companies are now allowed to affiliate with one another through the creation of a new financial holding company structure. Although the Act empowers the Federal Reserve Board to be the "umbrella" supervisor for the financial holding companies, its authority is limited over the operating units of these companies that are regulated by the other federal banking agencies and the nonbank functional regulators - the so-called "Fed-lite" provision. ${ }^{30}$ While providing broad guidelines, the Act does not specifically lay out how umbrella and functional supervision should be implemented in practice.

\section{The staff noted that some market participants and observers had questioned the} strength of the Federal Reserve's supervisory powers under the GLB Act. This division of

${ }^{29}$ The forthcoming selected issues paper discusses in more detail the GLB Act, its implications for further financial sector consolidation, and the challenges for financial sector supervision and regulation.

${ }^{30}$ For example, a financial holding company regulated and supervised by the Federal Reserve, may own a bank which is regulated by the Office of the Comptroller of the Currency, a broker dealer by the Securities and Exchange Commission; a commodity trading operation by the Commodity Futures Trading Commission; and an insurance company by a state insurance regulator. 
responsibilities also has raised some concems that the Federal Reserve might not have the type of information that it may need to carry out its responsibility to safeguard the stability of the financial system and sufficient access to information to effectively supervise the new financial holding companies. The functional regulators do not have mandates to protect the stability of the overall financial system, and in the event of a fast-breaking crisis, close cooperation among supervisory agencies would be required. Federal Reserve officials responded that consolidation and mergers between different parts of the financial services industry had already been underway for some time. The Act might eventually accelerate this process, but the challenges to financial supervision posed by increasingly large, complex institutions were already present. The authorities noted that for many years now there has been means of coordinating the activities and exchanging information between supervisors, and that in crises in the past, they have managed to respond promptly even in cases where there were split supervisory responsibilities. They acknowledged that it was inevitable that the new system will be tested, and only as experience is gained in operating under the new structure will potential problems be identified and ironed out. They also emphasized that the focus was on ensuring that sound risk-management systems were in place. In this regard, the staff noted that one possible approach to enhancing the role of markets in supervising financial institutions would be to require banking organizations to regularly issue a homogenous subordinated debt instrument. ${ }^{31}$ The authorities pointed out that the GLB Act required the Treasury and the Federal Reserve to prepare a report on using subordinated debt for large banking organizations.

\section{The sharp rise in margin debt-by about 75 percent in the year through March} 2000 to a peak of $\$ 279$ billion-raised questions about whether this borrowing could increase the risks of financial turmoil in the event of a sharp drop in the stock market, and whether the Federal Reserve should raise the margin requirement. ${ }^{32}$ The steep decline in the price of technology stocks since March led to a decline in outstanding margin borrowing of about 10 percent in April. The authorities noted that margin loans accounted for a small fraction of market capitalization (about 1/1/2 percent), and empirical evidence did not indicate that margin borrowing had a significant effect on either the level or volatility of the market. Since access to credit for stock purchases was widely available to investors from alternative sources, the Federal Reserve officials did not think that adjusting margin requirements would have a significant impact. They cautioned that raising margin requirements might reduce

${ }^{31}$ Some of the pros and cons of requiring the regular issuance of a subordinated debt instrument are discussed in the forthcoming selected issues paper.

32 Under Federal Reserve regulations, individual investors may borrow no more than 50 percent of the initial value of shares purchased, a limit that has remained unchanged since 1974. Brokerages often impose higher limits, especially for more volatile stocks, and link the margin requirement to the current market value of the stock, but these limits vary substantially among institutions. 
liquidity in a falling market as individuals' capacity to finance stock purchases would be constrained.

51. The rapid expansion of over-the-counter (OTC) derivatives markets in recent years, and perceived weaknesses in counterparty risk management in derivative transactions have raised concerns and prompted ongoing private and public sector evaluations and recommendations. ${ }^{33}$ A number of market participants had commented to the Fund staff' $s$ International Capital Markets mission that substantial progress had not yet been achieved in improving counterparty risk assessment and management, closeout procedures, and netting arrangements. Market discipline needed to be enhanced to avoid the kind of systemic risk associated with the near collapse in 1998 of Long-Term Capital Management. Although the Federal Reserve officials appreciated the risks associated with the OTC derivatives market, they believed that the market's self discipline mechanisms generally worked well; supervisors continued to emphasize to financial institutions the importance of improving risk management, stress testing, and financial disclosure.

52. The staff noted that the U.S. trading system was relatively transparent, and that the strength of the U.S. economy has generally helped to contain protectionist pressures. The staff observed, however, that a strong dollar and the weakness of economic activity abroad had contributed to increased resort to antidumping $(A D)$ and countervailing duty (CVD) actions in 1998 and 1999. Greater use of AD/CVD appeared to reflect an undercurrent of protectionist pressure that likely would intensify if economic activity in the United States were to weaken significantly. The U.S. representatives considered that it was inappropriate to focus on $\mathrm{AD} / \mathrm{CVD}$ actions in isolation, since such measures served as a buffer against external trade shocks that ultimately helped to control protectionist pressures. The staff questioned whether these measures were well-suited to that purpose, and noted that the Administration has stressed the importance of fostering market competition as a means of promoting economic efficiency. The staff added that recasting these trade remedies to ensure that foreign producers did not threaten the competitive environtnent (in line with the objectives of antitrust laws), instead of using them more generally to provide relief to domestic producers in cases where import penetration has increased, would promote the overall efficiency of the economy. A useful first step in this direction would be for the United States to follow the lead of some other industrial countries by adopting a provision that would guarantee a substantive role for public-interest considerations, giving weight to the interests of both producers and consumers, in the administration of antidumping and countervailing duties. ${ }^{34}$

${ }^{33}$ Examples include the work of the President's Working Group on OTC derivatives, the guidance from bank supervisors following the Long-Term Capital Management crisis, and the work of the Counterparty Risk Management Policy Group.

${ }^{34}$ Canada, for example, provides interested parties the right to make representations to the Canada International Trade Tribunal on the question of whether the imposition of duties is in 


\section{The authorities indicated that while the multilateral trading system formed the} backbone of U.S. efforts toward freer world trade, they also pursued this goal through regional, sectoral, and bilateral initiatives in keeping with WTO rules. They emphasized the importance of keeping the process moving forward on all these fronts in order to maintain momentum toward trade liberalization. The U.S. representatives indicated that it was unclear whether there would be adequate support to launch a new multilateral trade round later this year, but they indicated that the built-in agenda of the Uruguay Round was on track, including talks on agriculture and services trade. At the same time, they were working to mobilize support for a new trade round. Further experience with the WTO's disputesettlement process continued to demonstrate its effectiveness, and the U.S. representatives were pleased that a pragmatic approach had been taken to deal with certain procedural ambiguities in the WTO's Dispute Settlement Understanding (DSU) that had caused delays in the resolution of a few high-profile cases. The staff welcomed the improvements in market access provided by the recently enacted African Growth and Opportunity Act and the Caribbean Basin Initiative, and encouraged the authorities to make further efforts to extend enhanced market access to the least-developed countries.

\section{Official development assistance (ODA) levels were envisaged under the} Administration's FY 2001 Budget to remain at relatively low levels as a percent of GDP over the five-year budget horizon. Such assistance rose from $\$ 8.8$ billion (0.1 percent of GNP) in 1998 to $\$ 9.1$ billion (0.1 percent of GNP) in 1999 (Tables 9 and 10). ${ }^{35}$ While welcoming the small increase, the staff noted that ODA as a percent of GNP was still near its recent historical low. The authorities responded that the Administration remained committed to well-targeted assistance toward countries that were undertaking market-oriented reforms. In addition, they emphasized that they continued to support initiatives designed to help highly indebted poor countries (the HIPC initiative). In September 1999, the President announced that the United States would cancel 100 percent of the debt that HIPC-eligible countries owed to the United States (this was subsequently authorized by Congress).

\section{STAFF APPRAISAL}

\section{Sound monetary and fiscal policies have contributed to making the current U.S.} economic expansion the longest on record. The federal fiscal balance has improved steadily since 1992, and budget surpluses were recorded in 1998 and 1999, the first time in more than 40 years that there were consecutive surpluses. Government debt held by the public has declined sharply as a share of GDP, and a continuation of current policies holds the prospect of eliminating the public debt early in the next decade. Monetary policy has helped the U.S.

the public interest. Although this provision has not been used frequently, amendments to Canada's Special Imports Measures Act came into force in April 2000 that should help to strengthen the role of public interest considerations. 
expansion to maintain its footing through a number of shocks, while inflation remains low and unemployment has fallen to levels not seen in 30 years. The favorable fiscal outlook, rising national saving, and low inflation have laid the foundation for strong investment spending which, in turn, has facilitated high rates of growth in both productivity and real income. The U.S. authorities are to be highly commended for these accomplishments.

56. The strength of the U.S economic expansion played a critical role in supporting world economic growth during the period of turbulence in 1997-98, and it has also provided significant support to the global recovery that now appears to be well underway. This growth in U.S. domestic demand in excess of supply has been reflected in a large and growing external current account deficit. At the same time, large external surpluses in Japan and, to a lesser extent, in the euro area have emerged. The sustainability of the large U.S. current account deficit hinges on the ability of the United States to continue to attract sizable capital inflows. Up to now these inflows in large part have reflected the perceived attractiveness of the U.S. investment environment, but such perceptions are subject to continuous reappraisal. If the uneven pattern of world growth which has prevailed in recent. years were to persist much longer, it would raise concerns that external imbalances among the major economies would widen substantially further, increasing the risk of an abrupt reversal with potentially adverse consequences worldwide. Signs of stronger growth in the euro area are encouraging, but prospects for a significant pickup in demand in Japan are still unclear, and appropriate policies in these countries will be needed to promote the sustained expansion of their economies. In the United States, the policies that will best serve the key U.S. domestic objective of sustaining noninflationary growth will also contribute to a smooth rebalancing of global demand.

57. The strength of U.S. aggregate demand has been supported by rising real incomes, enhanced profitability, and rapidly growing household wealth-all of which are closely related to the surge in productivity experienced in the United States in the second half of the 1990s. This productivity surge also has been a primary factor underlying the attractive investment environment in the United States, drawing in substantial flows of capital, pushing up the value of the dollar, and contributing to a sharp widening of the current account deficit. The sustainability of current high stock market valuations will depend to a considerable extent on how prolonged will be the factors underlying the surge in productivity growth, and thus the outlook for corporate earnings. Capital deepening and the diffusion of information: technologies appear to underlie much of the increase. At this juncture, there is no way of knowing how long this process might continue to support these high levels of productivity growth, with their associated favorable effects on real incomes, profits, and wealth. Nevertheless, it is clear that continued domestic demand growth at a pace well in excess of the productivity-driven increases in potential output is not sustainable. If not reined in, such rapid demand growth threatens to undermine the prospects for sustained noninflationary growth.

58. In these circumstances, the staff believes that the principal policy priority for the United States in the near term is to ensure that the pace of aggregate demand gronth is brought back in line with the economy's potential growth in supply in order to keep 
inflation in check. The prospect that those factors which have helped to contain inflationary pressures over the past few years - such as restrained growth in employee benefits and weak import and non-oil commodity prices - may begin to reverse adds to the need for decisive policy action to slow demand growth. The Federal Reserve has acted appropriately, raising short-term interest rates by a further 50 basis points at the May FOMC meeting. Although it did not raise the federal funds rate further in June, the FOMC indicated its concern that the risks going forward continued to be mainly weighted toward conditions that might generate heightened inflationary pressures. The staff believes a further tightening of monetary policy will be required to ensure that inflation remains under control. How much more interest rates will need to be increased will depend on how the economy responds to past and subsequent steps to tighten policy, and whether there are additional indications of emerging wage and price pressures in the period ahead. Although tighter U.S. monetary policy will inevitably have spillover effects on the rest of the world, including for the cost of financing in the emerging market countries, the impact would be even more detrimental for these countries if the U.S. authorities were to delay a policy response and subsequently needed to tighten monetary policy more sharply once inflationary pressures had strengthened.

\section{Fiscal policy also has an important role to play in restraining domestic demand}

growth in the near term. Preserving the fiscal surpluses in prospect entails the withdrawal of a significant stimulus to demand, whereas measures to substantially cut taxes or raise spending would add to demand at an inappropriate time and thereby jeopardize the continued noninflationary expansion of the economy. Indeed, a tightening of the fiscal stance would alleviate the burden on monetary policy, and thereby reduce some of the upward pressure on U.S, interest rates that could increase the dollar's value and exacerbate global current account imbalances. By helping to raise the level of national saving, maintaining a tight fiscal position would also help to ensure an orderly correction in the current account imbalance and in the real value of the dollar over the medium term. Moreover, although the underlying fiscal position appears to be very solid, the simple fact that changing economic conditions could significantly alter medium-term budgetary prospects argues strongly for caution in introducing new expansionary fiscal measures; it would be better to use stronger-thanexpected fiscal surpluses to pay down the public debt more rapidly.

\section{To ensure that budget discipline is maintained, the Administration in its FY 2001 budget proposes to extend through FY 2010 the discretionary spending caps and the} $P A Y G O$ financing requirement. These budget enforcement mechanisms have played an important role in the improvement in the fiscal position since 1992. Under the Administration's proposal, the discretionary spending caps would be raised in FY 2001 to reflect currently enacted levels of spending and to ensure that adequate levels of basic government services are maintained. Thereafter, the caps would rise roughly in line with inflation; PAYGO would be extended without modification. The staff agrees that adjustments are necessary to make the discretionary spending caps more realistic; however, once this has been done and these budget enforcement mechanisms have been extended, the discipline imposed by the caps and PAYGO should be re-established. 
61. In the FY 2001 Budget, the Administration continues its practice of proposing small targeted tax cuts to promote specific economic and social objectives. Repeated resort to such tax expenditures adds to the complexity of the tax code, undermining transparency and increasing compliance costs. The staff continues to take the view that the authorities should limit recourse to the use of targeted tax cuts. The underlying objectives of most of the measures proposed might better be addressed through spending programs.

\section{The Administration's intention to preserve a substantial portion of the budget} surpluses in prospect under current services over the longer term is laudable, and the staff welcomes the view recently expressed by the Secretary of the Treasury that there is a compelling argument for establishing as a medum-term fiscal policy objective the elimination of the net government debt held by the public. Elimination of the public debt would be an important step in preparing the federal government for the coming long wave of unfunded liabilities associated with the aging of the population, as the first of the baby-boom generation starts to retire around 2010. Indeed to meet these obligations fully, the overall fiscal position may need to remain in surplus for a while even after the public debt has been retired. In this context, the staff believes that a reasonable medium-term fiscal policy objective could be to adopt measures to eliminate the actuarial imbalances facing Social Security and Medicare HI, and then attempt to keep the remainder of the budget roughly in balance on average over the business cycle. This might be facilitated if revenues and expenditures of Social Security and Medicare HI were more formally separated from the rest of the federal budget, in order to help mitigate pressures to divert surpluses in these programs to other uses.

\section{The Administration's plan for strengthening the long-term financial outlook of} Social Security and Medicare shores up their future economic viability by reducing the public debt and by transferring on-budget resources to the programs. Such resource transfers could risk softening budget constraints that have helped over the years to restrain spending, although this nisk might be reduced by the Administration's proposal to link these transfers to part of the interest saving from retiring the public debt. However, once the precedent was set, it could be easier to justify further on-budget transfers to finance extensions of benefits. In the view of the staff, relatively small adjustments in the parameters of both the Social Security and Medicare systems (such as a combination of small payroll tax increases and benefit cuts), if put in place soon, would be sufficient to meet the future liabilities of the programs based on current estimates of these liabilities. Particularly in the case of Medicare, however, it has to be recognized that, because of the uncertainties associated with projecting future health care costs, additional periodic adjustments to the program's parameters are likely to be required, and a mechanism for routinely making such adjustments will need to be established. The staff also takes the view that it would be better for the Administration to ensure that the current long-term financial shortfall is fully addressed before adopting new Medicare benefits.

64. Although at present the authorities do not see major wulnerabilities in the banking sector that might contribute to triggering a downturn in economic activity, they have been prudently cautious in their supervision of banks, and the staff is impressed by their 
determination not to be complacent. Any downturn in the economy will inevitably produce some financial distress as falling incomes and profits create debt-servicing difficulties for some households and businesses. In this context, the staff strongly supports the authorities' efforts to be pre-emptive and to limit the scope of such potential future financial distress by appropriately cautioning bark lending officers against loosening lending standards and making loans on the basis of the tenuous assumption that current favorable economic conditions will continue uninterrupted.

65. The Gramm-Leach-Bliley Act represents a much needed overhaul of the badly outdated laws regulating the financial sector in the United States. The expanded opportunities for new financial holding companies to engage in banking, securities, and insurance activities and the new regulatory supervisory structure provided for under the law pose significant new challenges. In particular, the Act provides broad guidelines without laying out specifically how the supervisory responsibilities of the Federal Reserve, the other federal banking agencies, and the nonbank functional supervisors (including the Securities and Exchange Commission, the Commodity Futures Trading Commission, and the state-level insurance commissioners) are to be implemented in practice. To address concerns raised by some market participants about this division of responsibilities, the Federal Reserve is working to adapt its supervisory approach to ensure it is fully effective; to work more closely with other supervisory agencies; and to avoid an extension of the banking safety net. The authorities have rightly emphasized that the central supervisory challenge will be to ensure that the large, more complex financial institutions that are emerging have sufficiently robust risk-management systems. They have also indicated their interest in making more use of market information and discipline in supervising financial institutions. In this context, one possible approach that is being considered by the authorities is to require the regular issuance by large banks of a uniform subordinated debt instrument.

\section{The strength of the U.S. economy has generally helped to contain protectionist} pressures, but a strong dollar and the weakness of economic activity abroad contributed to increased resort to antidumping $(A D)$ and countervailing duty (CVD) actions in 1998 and 1999. It is in the interest of both the United States and the international community that such protectionist pressures be strongly resisted, even pressures arising through WTO-approved trade remedies like $\mathrm{AD} / \mathrm{CVD}$. As a general rule, the Administration has stressed the importance of, and has taken measures aimed at, enhancing market competition throughout the economy. Consistent with this policy approach, the staff believes a change in the administration of $\mathrm{AD} / \mathrm{CVD}$ procedures is called for, such that import protection would be provided only in those cases where foreign producers were found to be engaged in anticompetitive behavior.

67. The United States should continue to be a major force for the further liberalization of world trade through efforts to initiate a new round of multilateral negotiations and in the sectoral negotiations currently scheduled in the areas of agriculture and services. The United States has also worked constructively with authorities in other countries to reach a pragmatic solution to improve the functioning of the dispute-settlement mechanism, which is an essential element in the WTO's rules-based approach to international trade. The 
improvements in market access provided in the African Growth and Opportunity Act and in the Caribbean Basin Initiative are useful steps to enhance growth prospects for the countries of these regions, and the staff encourages the authorities to broaden firther duty-free access to the U.S. market for the least-developed countries.

68. Official development assistance (ODA) rose slightly in 1999 to 0.1 percent of GNP, but remains near its recent historical low level. Under the FY 2001 Budget, ODA would remain at this low level over the five-year budget horizon. The staff urges the authorities to make further efforts to raise foreign assistance. At the same time, the staff welcomes the Administration's support for the enhanced HIPC initiative, encouraging the U.S. government to complete the necessary financing arrangements.

69. The quality, coverage, periodicity, and timeliness of U.S. economic data are considered to be excellent both in the context of the Article IV consultation and for purposes of ongoing surveillance. The United States has subscribed to the Special Data Dissemination Standard and its metadata are posted on the Dissemination Standard Bulletin Board.

70. It is recommended that the next Article IV consultation takes place within the standard 12-month cycle. 
United States: Fund Relations

(As of May 31, 2000)

I. Membership Status: Joined 12/27/45; Article VIII

II. General Resources Account:

Quota

Fund holdings of currency

Reserve position in Fund

Operational budget transfers (net)

III. SDR Department:

Net cumulative allocation

Holdings
SDR Million

$37,149.30$

$25,498.63$

$11,646.11$

$-438.00$

SDR Million

$4,899.53$

$7,810.15$
Percent

Quota

100.0

68.6

31.3

Percent

Allocation

100.0

159.4

IV. Outstanding Purchases and Loans: None

V. Financial Arrangements: None

VI. Projected Obligations to Fund: None

VII. Payments Restrictions: The United States has notified the Fund under Decision No. 144 of restrictions on payments and transfers for current international transactions to Libya $_{,}$Iraq, North Korea, Cuba, and Iran. The United States restricts the sale of arms and petroleum to UNITA and to the territory of Angola and has prohibitions against transactions with terrorists and international narcotics traffickers. The United States notified the Fund under Decision No. 144 on August 2, 1995 of the imposition of further restrictions on current transactions with Iran (EBS/95/107).

VIII. Statistical Issues: The quality, coverage, periodicity, and timeliness of U.S. economic data are considered to be excellent both in the context of the Article IV consultation and for purposes of ongoing surveillance (see Attachment for a summary). The United States has subscribed to the Special Data Dissemination Standard (SDDS) and its metadata are posted on the Dissemination Standard Bulletin Board (DSBB). 


\section{United States of America: Core Statistical Indicators}

as of June 30,2000

\begin{tabular}{|c|c|c|c|c|c|c|c|c|c|c|c|c|}
\hline & $\begin{array}{c}\text { Exchange } \\
\text { Rates }\end{array}$ & $\begin{array}{l}\text { Interna- } \\
\text { tional } \\
\text { Reserves }\end{array}$ & $\begin{array}{c}\text { Central } \\
\text { Bank } \\
\text { Balance } \\
\text { Sheet }\end{array}$ & $\begin{array}{l}\text { Reserve/ } \\
\text { Base } \\
\text { Money }\end{array}$ & $\begin{array}{l}\text { Broad } \\
\text { Money }\end{array}$ & $\begin{array}{l}\text { Interest } \\
\text { Rates }\end{array}$ & $\begin{array}{l}\text { Consumer } \\
\text { Price } \\
\text { Index }\end{array}$ & $\begin{array}{l}\text { Exports/ } \\
\text { Imports }\end{array}$ & $\begin{array}{l}\text { Current } \\
\text { Account } \\
\text { Balance }\end{array}$ & $\begin{array}{c}\text { Overall } \\
\text { Govern- } \\
\text { ment } \\
\text { Balance }\end{array}$ & $\begin{array}{l}\text { GDP! } \\
\text { GNP }\end{array}$ & $\begin{array}{l}\text { External } \\
\text { Debt/Debt } \\
\text { Service }\end{array}$ \\
\hline $\begin{array}{l}\text { Date of latest } \\
\text { observation }\end{array}$ & $\begin{array}{l}\text { Same } \\
\text { day }\end{array}$ & May 2000 & June 21 & June 21 & June 21 & $\begin{array}{l}\text { Same } \\
\text { day }\end{array}$ & $\begin{array}{l}\text { May } \\
2000\end{array}$ & $\begin{array}{l}\text { April } \\
2000\end{array}$ & $2000 Q 1$ & $\begin{array}{l}\text { May } \\
2000\end{array}$ & $2000 Q 1$ & 1998 \\
\hline Date released & $\begin{array}{l}\text { Same } \\
\text { day }\end{array}$ & June 20 & June 23 & June 23 & June 23 & $\begin{array}{l}\text { Same } \\
\text { day }\end{array}$ & June 14 & June 20 & June 20 & June 20 & June 29 & July 1999 \\
\hline $\begin{array}{l}\text { Frequency } \\
\text { of data }\end{array}$ & daily & monthly & weekly & weekly & weekly & daily & monthly & monthly & quarterly & monthly & quarterly & annual \\
\hline $\begin{array}{l}\text { Frequency } \\
\text { of reporting }\end{array}$ & daily & monthly & weekly & weekly & weekly & daily & monthly & monthly & quarterly & monthly & monthly & annual \\
\hline Source of data & $\begin{array}{l}\text { Federal } \\
\text { Reserve }\end{array}$ & Treasury & $\begin{array}{l}\text { Federal } \\
\text { Reserve }\end{array}$ & $\begin{array}{l}\text { Federal } \\
\text { Reserve }\end{array}$ & $\begin{array}{l}\text { Federal } \\
\text { Reserve }\end{array}$ & $\begin{array}{l}\text { Federal } \\
\text { Reserve }\end{array}$ & $\begin{array}{l}\text { Dept. of } \\
\text { Labot }\end{array}$ & $\begin{array}{l}\text { Dept of } \\
\text { Commerce }\end{array}$ & $\begin{array}{l}\text { Dept. of } \\
\text { Commerce }\end{array}$ & Treasury & $\begin{array}{c}\text { Dept. of } \\
\text { Commerce }\end{array}$ & $\begin{array}{l}\text { Dept. of } \\
\text { Commene }\end{array}$ \\
\hline $\begin{array}{l}\text { Mode of } \\
\text { reporting } 1 /\end{array}$ & electronic & electronic & electronic & electronic & electronic & electronic & electronic & electronic & electronic & electromic & electronic & electronic \\
\hline Confidentiality & none & none & none & none & none & none & none & none & none & none & none & none \\
\hline $\begin{array}{l}\text { Frequency of } \\
\text { Publication }\end{array}$ & daily & monthly & weekly & weekly & weekly & daily & monthly & monthly & quarterly & monthly & monthly & annual \\
\hline
\end{tabular}

1/ Most data are available from statistical releases and from private electronic databases. 
Table 1. United States: Historical Economic Indicators

\begin{tabular}{|c|c|c|c|c|c|c|c|c|c|}
\hline & \multicolumn{3}{|c|}{ Avergegs } & \multirow[b]{2}{*}{1994} & \multirow[b]{2}{*}{1995} & \multirow[b]{2}{*}{1996} & \multirow[b]{2}{*}{1997} & \multirow[b]{2}{*}{1998} & \multirow[b]{2}{*}{1999} \\
\hline & 19605 & $1970 \mathrm{~s}$ & $1980 \mathrm{~s}$ & & & & & & \\
\hline \multicolumn{10}{|l|}{ Econcmic activity and prices } \\
\hline Real GDP & 4.4 & 3.3 & 3.0 & 4.0 & 2.7 & 3.6 & 4.2 & 43 & 4.2 \\
\hline Real net exports $1 /$ & 0.0 & 0.2 & -8.1 & -0.4 & 0.1 & -0.2 & -03 & -1.2 & -1.1 \\
\hline Real final donestic demand & 4.4 & 3.1 & 3.0 & 3.8 & 3.0 & 3.7 & 4.0 & 5.4 & 5.5 \\
\hline Private final consumption & 4.4 & 3.5 & 3.2 & 3.8 & 3.0 & 3.2 & 3.4 & 49 & 5.3 \\
\hline Nomresidential fixed investment & 7.2 & 5.4 & 3.3 & 8.9 & 9.8 & 10.0 & 10.7 & 12.7 & 8.3 \\
\hline Labor force & 1.7 & 2.7 & 1.7 & 1.4 & 1.0 & 1.2 & 1.8 & 1.0 & 1.2 \\
\hline Employmurnt & 1.9 & 2.4 & 1.7 & 2.3 & 1.5 & 1.4 & 22 & 1.5 & 1.5 \\
\hline Unemployment rate & 4.8 & 6.2 & 7.3 & 6.1 & 5.6 & 5.4 & 4.9 & 4.5 & 4.2 \\
\hline Labor productivity 2 & 2.9 & 20 & 1.4 & 1.3 & 0.9 & 26. & 1.6 & 2.8 & 3.0 \\
\hline Toral facior productivity $2 /$ & 1.9 & 1.1 & 0.1 & 0.4 & 0.3 & 1.5 & 0.4 &... & $\ldots$ \\
\hline Capital stock $3 /$ & 3.7 & 3.5 & 2.7 & 2.3 & 2.4 & 28 & 2.9 & 3.3 & $\cdots$ \\
\hline GDP deflater & 2.4 & 6.6 & 4.8 & 2.1 & 2.2 & 1.5 & 19 & 1.2 & 1.5 \\
\hline Inplicit price dellator for GDP & 2.4 & 6.6 & 4.8 & 2.1 & 2.2 & 1.9 & 1.9 & 1.2 & 1.5 \\
\hline Consunter price index & 2.3 & 7.1 & 5.6 & 2.6 & 2.8 & 29 & 23 & 1.6 & 22 \\
\hline Uhit labor cost $2 /$ & 2.1 & 6.3 & 4.3 & 0.8 & 1.2 & 0.5 & 19 & 2.4 & 1.6 \\
\hline Noraingl effective exchange rate 4 / & 0.5 & -2.4 & 0,2 & -1.8 & -6.0 & 5.2 & 8.1 & 4.9 & -2.5 \\
\hline Real effective exchange rale 4 / & $\ldots$ & $\ldots$ & $\ldots$ & -1.0 & -6.4 & 60 & 8.9 & 6.7 & 1.0 \\
\hline Three-month Treasury bill rate (percent) $5 /$ & 4.0 & 6.3 & 8.8 & 4.2 & 5.5 & 5.0 & 5.1 & 4.8 & 4.6 \\
\hline \multirow[t]{2}{*}{ Ter-year Treasury note nate (percent) $5 i$} & 4.7 & 7.5 & 10.6 & 7.1 & 6.6 & 6.4 & 6.4 & 5.3 & 5.6 \\
\hline & \multicolumn{9}{|c|}{ (In percent of GDP or NNP) } \\
\hline \multicolumn{10}{|l|}{ Balance of payments } \\
\hline Current account & 0.5 & 0.0 & -1.7 & -1.7 & -1.5 & -1.6 & .1 .7 & -2.5 & -3.6 \\
\hline Merchatdise tratde balaner & 0.6 & -0.5 & -2.2 & -2.4 & -2.3 & -2.4 & -2.4 & -2.8 & -3.7 \\
\hline Invisibles, net & $=0.1$ & 0.5 & 0.5 & 0.7 & 0.9 & 0.9 & 0.7 & 0.3 & 0.2 \\
\hline Real net exports 6 & -1.2 & -1.4 & -1.5 & -1.2 & -1.0 & -1.1 & -1.4 & -2.6 & -3.7 \\
\hline \multicolumn{10}{|l|}{ Fiscal indicators } \\
\hline Unifited Federal balance (Fiscal yedr) & -0.8 & -2.1 & -3.9 & -2.9 & -2.2 & -1.4 & -0.3 & 0.8 & 1.4 \\
\hline Structural Balance (Fiscal year) 7 & $\ldots$ & $\cdots$ & $\ldots$ & -2.1 & -1.5 & -0.7 & 0.2 & 1.1 & 1.4 \\
\hline Central govemment fiscal balance (NIPA) 81 & -0.1 & -1.7 & -3.8 & -3.0 & -2.6 & -1.8 & -0.5 & 0.6 & $\ldots$ \\
\hline General govemment fiscol balance (NIPA) $8{ }^{\prime}$ & -1.2 & -2.4 & -4.4 & -3.8 & -3.3 & -24 & -1.2 & 0.1 & $\cdots$ \\
\hline \multicolumn{10}{|l|}{ Savings and ithestenetix of } \\
\hline Gross national saving & 21.0 & 19.7 & 18.5 & 16,4 & 17.0 & 17.3 & 18.3 & 18.8 & 18.7 \\
\hline General government & 4.0 & 1.3 & -0.8 & -0.6 & -0.1 & 0.8 & 1.9 & 3.1 & 3.9 \\
\hline Of which: Federal govenument & 2.2 & -0.5 & -2.2 & -1.9 & -1.5 & -0.7 & 0.5 & 1.5 & 2.2 \\
\hline Frivate & 17.1 & 18.4 & 19.2 & 170 & $17 . i$ & 16.5 & 16.4 & 15.7 & 14.7 \\
\hline Persona] & 5.7 & 6.8 & 6.7 & 4.5 & 4.1 & 3.5 & 3.3 & 2.6 & 1.7 \\
\hline Business: & 11.4 & 11.6 & 12.6 & 12.5 & 13.0 & 13.0 & 13.1 & 13.0 & 13.1 \\
\hline Gross domestic investment & 20.7 & 30.4 & 20.5 & 18.8 & 18.7 & 19.1 & 19.8 & 20.5 & 20.7 \\
\hline Frivate & 153 & 16.7 & 16.9 & 15.6 & 15.5 & 15.9 & 16.7 & 17.5 & 17.5 \\
\hline Fublic & 5.2 & 3.7 & 3.6 & 3.2 & 3.2 & 3.2 & 3.1 & 3.1 & 3.2 \\
\hline Of which: Federal government & 2.4 & 1.3 & 1,6 & 1.2 & 1.1 & 1.1 & 1.0 & 1.0 & 1.0 \\
\hline Wet foreign investment & 0.6 & 0.2 & -1.5 & -1.5 & -1.3 & -1.4 & -1.5 & -2.3 & -3.4 \\
\hline Net national saving & 150 & 12.4 & 9.3 & 7,1 & 7.9 & 8.3 & 9.5 & 10.0 & 9.7 \\
\hline Nel privale invesment & 8.8 & 9.0 & 7.5 & 62 & Q.] & 6.7 & 7.6 & 8.5 & 8.4 \\
\hline \multicolumn{10}{|l|}{ In real terns } \\
\hline Gross dowertic infestment & 57.1 & 16.6 & 17.3 & 18.3 & 18.3 & 19.1 & 20.2 & 21.3 & 21.6 \\
\hline Privete & 12.4 & 13.6 & 14.1 & 15.1 & 15.1 & 15.9 & 17.0 & 18.2 & 18.5 \\
\hline Public & 4.7 & 3.0 & 3,1 & 3.2 & 3.2 & 3.2 & 3.1 & 3.1 & 3.1 \\
\hline
\end{tabular}

Sources: U.S. Department of Commerce, Burean of Econcmic Analysis; and Bcard of Govemors of the Federel Reserve System.

1/ Contribution to GDP grouxh

2 Private nonfarm busisess sector.

3/ Business sector, in chained 1996 dollars except for historieal averages which are in chained 1992 dollars.

4 Monthly average on an unt labor cost basis $(1990=100)$

5t Yearly arerage.

6/ On a IIPA basis.

if As a pertant of potential GDP.

s/ Overall balance - i.e., current belance minus net invertment

9/ Gross national saving does not equal gross donestic investment and net foreight investment because of capital grants and statistical diecrepancy. Net national saving and net private investment are expressed in pencent of NNP. 
Table 2. United States: Balance of Payments (In billions of dollars)

\begin{tabular}{|c|c|c|c|c|c|c|c|c|c|c|}
\hline & 1990 & 1991 & 1992 & 1993 & 1994 & 1995 & 1996 & 1997 & 1998 & 1999 \\
\hline Custent aecount & -77 & 7 & -48 & .83 & -119 & -109 & -123 & -141 & -217 & -331 \\
\hline Peroent of GDP & -1.3 & 0.1 & -0.8 & -1.2 & -1.7 & -1.5 & -1.6 & -1.7 & -2.5 & -3.6 \\
\hline Goods and services & .79 & -28 & -36 & -69 & -97 & -96 & -102 & -106 & -167 & -265 \\
\hline Mierohandise trade & -109 & -74 & -96 & -133 & -166 & .174 & -191 & -197 & .247 & -346 \\
\hline Exports & 389 & 417 & 440 & 457 & 502 & 576 & 612 & 680 & 670 & 684 \\
\hline Imports & -498 & -491 & -536 & -589 & -669 & -750 & -803 & -876 & -917 & $-1,030$ \\
\hline Services & 30 & 46 & 60 & 64 & 69 & 78 & 89 & 91 & 80 & 81 \\
\hline Receipts & 148 & 164 & 177 & 186 & 201 & 219 & 240 & 257 & 263 & 272 \\
\hline Payment & -118 & -118 & -116 & -122 & -132 & -141 & -151 & -167 & -183 & -191 \\
\hline Investment income & 29 & 24 & 23 & 24 & 17 & 2.1 & 19 & 6 & -6 & -18 \\
\hline Receipts & 172 & 149 & 132 & 134 & 165 & 212 & 224 & 257 & 258 & 276 \\
\hline Payment & -143 & -125 & -109 & -110 & -149 & -191 & .205 & 251 & -265 & -295 \\
\hline Unilateral transfers & -27 & 11 & -35 & -38 & -38 & -34 & -40 & -41 & -44 & -48 \\
\hline Government transfers & .10 & 29 & -16 & -17 & -15 & -11 & -15 & -12 & -13 & -14 \\
\hline Private transfers & -16 & -18 & -19 & -21 & -23 & -23 & -25 & -28 & -31 & -34 \\
\hline \multicolumn{11}{|l|}{ Capital account } \\
\hline transactions, net & -7 & -4 & 1 & 0 & 0 & 0 & 1 & 0 & 1 & 2 \\
\hline Finartcial account & 60 & 46 & 96 & 81 & 130 & 113 & 158 & 268 & 147 & 323 \\
\hline Private capital & 26 & 20 & 54 & 11 & 85 & 14 & 25 & 250 & 174 & 269 \\
\hline Direct investment & 11 & -15 & -28 & -33 & -34 & -41 & -5 & 1 & 40 & 125 \\
\hline Outflows & -37 & -38 & -48 & -84 & -80 & -99 & -92 & -105 & -146 & -151 \\
\hline Inflows & 48 & 23 & 20 & $\$ 1$ & 46 & $\$ 8$ & 87 & 106 & 186 & 276 \\
\hline Securities & -11 & 24 & 31 & -23 & 54 & 86 & 153 & 250 & 147 & 205 \\
\hline Outflows & -29 & -46 & -49 & -146 & -60 & -123 & -150 & -119 & -136 & -129 \\
\hline Intlows & 18 & 69 & 81 & 123 & 115 & 208 & 303 & 369 & 283 & 333 \\
\hline Net U.S. bank flows & 9 & 3 & 37 & 56 & 100 & -45 & -75 & 8 & 4 & -2 \\
\hline Nonbank capital & 17 & 8 & 13 & 11 & -35 & 14 & -47 & -9 & -18 & -58 \\
\hline U.S. official reserves & -2 & 6 & 4 & -1 & 5 & -10 & 7 & -1 & -7 & 9 \\
\hline Foreign official assets & 34 & 17 & 40 & 72 & 40 & 110 & 127 & 19 & -20 & 43 \\
\hline Other iteals & 2 & 3 & -2 & 0 & 0 & -1 & -1 & 0 & 0 & 3 \\
\hline Statistical discrepancy & 23 & -49 & -49 & $\mathbf{I}$ & -11 & -4 & .35 & -128 & 70 & 12 \\
\hline
\end{tabular}

Souroe: U.S. Department of Commerce, Bureant of Economic Analysis. 
Table 3. United States: Indicators of Econonuc Performance

\begin{tabular}{|c|c|c|c|c|c|c|c|c|c|}
\hline & \multirow[b]{2}{*}{1993} & \multirow[b]{2}{*}{1994} & \multirow[b]{2}{*}{1995} & \multirow[b]{2}{*}{1996} & \multirow[b]{2}{*}{1997} & \multirow[b]{2}{*}{1998} & \multirow[b]{2}{*}{1999} & \multicolumn{2}{|c|}{ Projention } \\
\hline & & & & & & & & 2000 & $\overline{2001}$ \\
\hline \multicolumn{10}{|c|}{ (Annuwl percent change) } \\
\hline \multicolumn{10}{|l|}{ Real GDP } \\
\hline United States & $2 . T$ & 4.0 & 2.7 & 3.6 & 4.2 & 4.3 & 4.2 & 4.9 & 3.1 \\
\hline Japsin & 0.3 & 0.6 & 1.5 & 5.0 & 1.6 & -2.5 & 0.2 & 1.4 & 1.8 \\
\hline Gernany : & -1.1 & 23 & 1.7 & 0.8 & 1.5 & 2.2 & 15 & 2.8 & 3.3 \\
\hline Canada & 2.3 & 4.7 & 28 & 1.5 & 4.4 & 3.3 & 4.5 & 4.4 & 2.7 \\
\hline France. Itaky, and United Kingdomi $2 /$ & 0.1 & 29 & 2.5 & 1.6 & 2.4 & 2.3 & 2.1 & 3.2 & 3.6 \\
\hline G-7 countries $3 i$ & 1.3 & 3.0 & 2.3 & 3.0 & 3.1 & 2.5 & 2.8 & 3.7 & 2.4 \\
\hline \multicolumn{10}{|l|}{ Real domestic demand } \\
\hline United Stales. & 3.3 & 4.4 & 2.5 & 3.7 & 4.5 & 5.4 & 5.1 & 5.7 & 3.4 \\
\hline Japan & 0.1 & 1.0 & 23 & 5.7 & 0.2 & -3.1 & 0.5 & 1.0 & 2.2 \\
\hline Gormany 1 & -1.0 & 2.2 & 1.7 & 0.3 & 0.7 & 25 & 23 & 2.1 & 3.1 \\
\hline Canede & 1.4 & 3.2 & 1.7 & 1.4 & 6.2 & 22 & 4.2 & 4.3 & 2.7 \\
\hline France, I taly, and United Kingdote $2 /$ & -1.6 & 2.4 & 1.8 & 1.5 & 2.3 & 3.6 & 3,0 & 3.1 & 2.9 \\
\hline G-7 wuntries 3 & 1.1 & 3.1 & 2.2 & 3.1 & 2.9 & 3.1 & 3.6 & 3.9 & 3.0 \\
\hline \multicolumn{10}{|l|}{ GDF deflator } \\
\hline United States & 2.4 & 2.1 & 2.2 & 1.9 & 1.9 & 12 & 1.5 & 2.1 & 2.3 \\
\hline Japanl & 0.6 & 0.2 & -0.6 & -1.4 & 0.7 & 03 & -9.9 & -1.1 & 0.4 \\
\hline Gamany $1 /$ & 3.7 & 25 & 2.0 & 1.0 & 0.8 & 1.0 & 1.4 & 1.0 & 1.6 \\
\hline Canada & 1.5 & 1.1 & 2.3 & 1.7 & 1.0 & -0.6 & 1.6 & 2.8 & 2.0 \\
\hline France, ltaly, and United Kingàom $2 /$ & 3.0 & 2.2 & 30 & 3.3 & 2.3 & 2.2 & 1.6 & 1.6 & 1.5 \\
\hline G-7 conntries 3 & 2.3 & 1.8 & 1.9 & 1.5 & 1.5 & 1.2 & 1.0 & 1.4 & 1.8 \\
\hline \multicolumn{10}{|c|}{ (As percent of GDP) } \\
\hline \multicolumn{10}{|l|}{ Aencral government financial balance } \\
\hline Unjted ștates & $-\$, 1$ & -3.8 & -3.3 & -2.4 & -12 & 4.1 & 8.7 & 1.4 & 1.4 \\
\hline Јарам1 & -16 & .2 .3 & -3.6 & -4.2 & -33 & -4.7 & .7 .4 & -8.2 & -6.3 \\
\hline Guimany $\mathrm{L}$ & -3.2 & -25 & -32 & -3.4 & -26 & -1.7 & -1.1 & -6.7 & -1.0 \\
\hline Cantada & -8.7 & -6.7 & -5.4 & -2.8 & 0.2 & 0.2 & 3.1 & 2.9 & 2.7 \\
\hline France, Italy, and United Kingdom $2 J$ & -7.8 & +7.1 & -6.3 & -5.3 & -25 & -1.8 & -0.7 & -0.8 & -0.4 \\
\hline G-7 countries 3 & -5.0 & -4.2 & -4.1 & -3.5 & -19 & -1.3 & -1.1 & -0.8 & -0.3 \\
\hline Gross savings & & & & & & & & & \\
\hline United States & 156 & 16.4 & 17.0 & 17.3 & 18.3 & 16.8 & 18.7 & 18.7 & 18.8 \\
\hline Japan & 327 & 31.5 & 30.7 & 31.5 & 31.4 & 29.9 & 28.6 & 29.0 & 29.1 \\
\hline Gemany 1 & 22.0 & 22.1 & 21.8 & 21.2 & 21.5 & 21.6 & $2 ! .2$ & 22.4 & 22.9 \\
\hline Canads & 13.1 & 15.4 & 17.6 & [8.] & 19.0 & 19.7 & 20.0 & 21.4 & 22.2 \\
\hline France, Italy, and United Kingdom $2{ }^{\prime}$ & 17.1 & 18.2 & 19.2 & 18.9 & 19.6 & 20.0 & 19.7 & 19.8 & 20.1 \\
\hline G-7 tountries 3 & 39.7 & 20.1 & 20.5 & 20.6 & 21.3 & 21.3 & 20.8 & 21.1 & 21.3 \\
\hline Fixed privule irwwistraenl (In noentinal ltm & & & & & & & & & \\
\hline United States & 14.1 & 14.7 & 150 & IS.5 & 158 & 16.7 & 17.0 & 17.4 & 17.5 \\
\hline Japen & 21.0 & 20.0 & 19.9 & 20.7 & 20.8 & 19.2 & 18.0 & 18.8 & 19.7 \\
\hline Gemany if & 20.2 & 20.5 & 202 & 19.6 & 19.5 & 19.3 & 19.1 & 19.3 & 19.5 \\
\hline Canada & 14.8 & 15.5 & 145 & 14.9 & 17.0 & 17.2 & 17.5 & 19.8 & 21.1 \\
\hline Frunce, ltaly, and United Kingdom $y^{\prime}$ & 14.7 & 14.5 & 149 & 15.1 & 150 & 15.9 & 16.4 & 16.8 & 17,1 \\
\hline G-7 countries 3 & 16.2 & 16.3 & 16.4 & 16.8 & 17.0 & 17.2 & 17.3 & 17.7 & 18.0 \\
\hline Fuced private invostment (In IEal terms) & & & & & & & & & \\
\hline United States & 13.6 & 14.2 & 14.7 & 15.5 & 162 & 17.3 & 18.0 & 18.8 & 19.4 \\
\hline Japan & 21.5 & 20.9 & 21.0 & 22.4 & 227 & 21.1 & 20.2 & 21.1 & 223 \\
\hline Germany if & 19.9 & 20.3 & 20.2 & 19.8 & 19.8 & 19.8 & 19.8 & 20.1 & 20.5 \\
\hline Carada & 14.7 & 15.1 & 14.4 & 15.3 & 173 & 17.4 & 18.2 & 19.0 & 19.6 \\
\hline France, Italy, and United Kingdom 2 & 15.0 & 14.9 & 15.3 & 15.6 & 15.8 & 16.6 & 17.2 & 17.5 & 17.8 \\
\hline G-7 countries 3 & 16.1 & 16.3 & I6.5 & 172 & 17.7 & 18.1 & I8.4 & 19.0 & 19.6 \\
\hline Current nccount balanie & & & & & & & & & \\
\hline United States & -1.2 & -1.7 & -1.5 & -1.6 & -1.7 & -2.5 & -3.6 & -4.2 & -4]$. \\
\hline Japan & $3: 1$ & 2.8 & 2.2 & $1 . A$ & 12 & 3.2 & 2.5 & 2.5 & 2.3 \\
\hline Germany 1 & -0.5 & -1.1 & -7.8 & -0.3 & -0.1 & -0.2 & -0.9 & -0.3 & 0.0 \\
\hline Canada & -3.9 & -2.3 & -0.8 & -0.5 & -1.0 & -8.8 & -0.4 & 1.0 & 0.9 \\
\hline Fratice, Italy, and United Kingdonn 2 & 0.0 & 0.5 & 0.8 & 1.5 & 2.1 & 1.4 & 0.7 & 0.6 & 0.7 \\
\hline G-7 countries 3 & $-4,9$ & -3.1 & -1.0 & 0,7 & -2.1 & -2.6 & -0.5 & 15 & 13 \\
\hline
\end{tabular}

Source: Staff estimates for the World Foonomic Outlook

I/ Data nefer to unified Germanyr

2/ Conposits for the country groups ane averuges of individual countries weighted by the average value of their jespextive GDPs converted using PPP weights Dver the preceding three years.

3/ Inchudes statistical diserepancies. 
Table 4. G-7 Countries: Labor Market Indicators. ${ }^{1}$

\begin{tabular}{lllllll}
\hline & United & & United & & \\
States & Japan & Germany & Kingdom & France & Italy & Canada \\
\hline
\end{tabular}

Labor productivity (average annual percent change) ${ }^{2}$

$\begin{array}{rrrrrrrr}1980-91 & 2.9 & 4.1 & 2.6 & 4.6 & 3.5 & 3.7 & 2.1 \\ 1992-98 & 42 & 3.1 & 4.1 & 0.8 & 4.1 & 2.1 & 1.9 \\ 1995 & 6.1 & 7.4 & 3.1 & -1.9 & 5.4 & 3.5 & 2.5 \\ 1996 & 2.1 & 5.9 & 3.5 & -1.5 & 0.4 & 0.9 & -1.5 \\ 1997 & 4.1 & 4.8 & 5.8 & 0.8 & 72 & 2.8 & 3.4 \\ 1998 & 4.8 & -0.8 & 4.4 & 1.1 & 3.4 & 0.2 & 0.6\end{array}$

Employment growth (average annual percent change)

$\begin{array}{crrrrrrr}1980-91 & 1.6 & 1.3 & 3.1 & 0.5 & 0.3 & 0.5 & 1.4 \\ 1992-999^{3} & 1.7 & 0.1 & -0.3 & 1.0 & 0.5 & -0.5 & 1.9 \\ 1995 & 1.5 & 0.0 & 0.0 & 1.8 & 0.8 & -0.6 & 1.9 \\ 1996 & 1.4 & 0.5 & -0.6 & 1.1 & 0.3 & 0.5 & 0.8 \\ 1997 & 2.2 & 1.1 & -0.4 & 1.8 & 0.5 & 0.4 & 2.3 \\ 1998 & 1.5 & -0.7 & 0.5 & 1.2 & 1.5 & 1.1 & 2.7 \\ 1999 & 1.5 & -0.8 & \ldots & 1.0 & 1.7 & 1.2 & 2.8\end{array}$

Unemployment rate (percent)

\begin{tabular}{rrrrrrrr}
$1980-91$ & 7.1 & 2.5 & 5.8 & 9.7 & 9.3 & 6.5 & 9.3 \\
$1992-99$ & 5.6 & 3.3 & 8.6 & 8.3 & 11.8 & 11.0 & 9.6 \\
1995 & 5.6 & 3.2 & 8.2 & 8.7 & 11.8 & 11.8 & 9.4 \\
1996 & 5.4 & 3.4 & 8.9 & 8.2 & 12.5 & 11.7 & 9.6 \\
1997 & 4.9 & 3.4 & 9.9 & 7.0 & 12.4 & 11.9 & 9.1 \\
1998 & 4.5 & 4.1 & 9.4 & 6.3 & 11.8 & 12.0 & 8.3 \\
1999 & 4.2 & 4.7 & 9.0 & 6.1 & 11.1 & 11.5 & 7.6 \\
\hline
\end{tabular}

Source: U.S. Department of Labor, Bureau of Labor Statistics.

1/ Country data are adjusted to be consistent with U.S. concepts.

2/ In the manufacturing sector.

3/ For Gemany the average is from 1992 to 1998. 
Table 5. United States: Economic Outlook

(In percent chenges from previous year, unless otherwise indicatef)

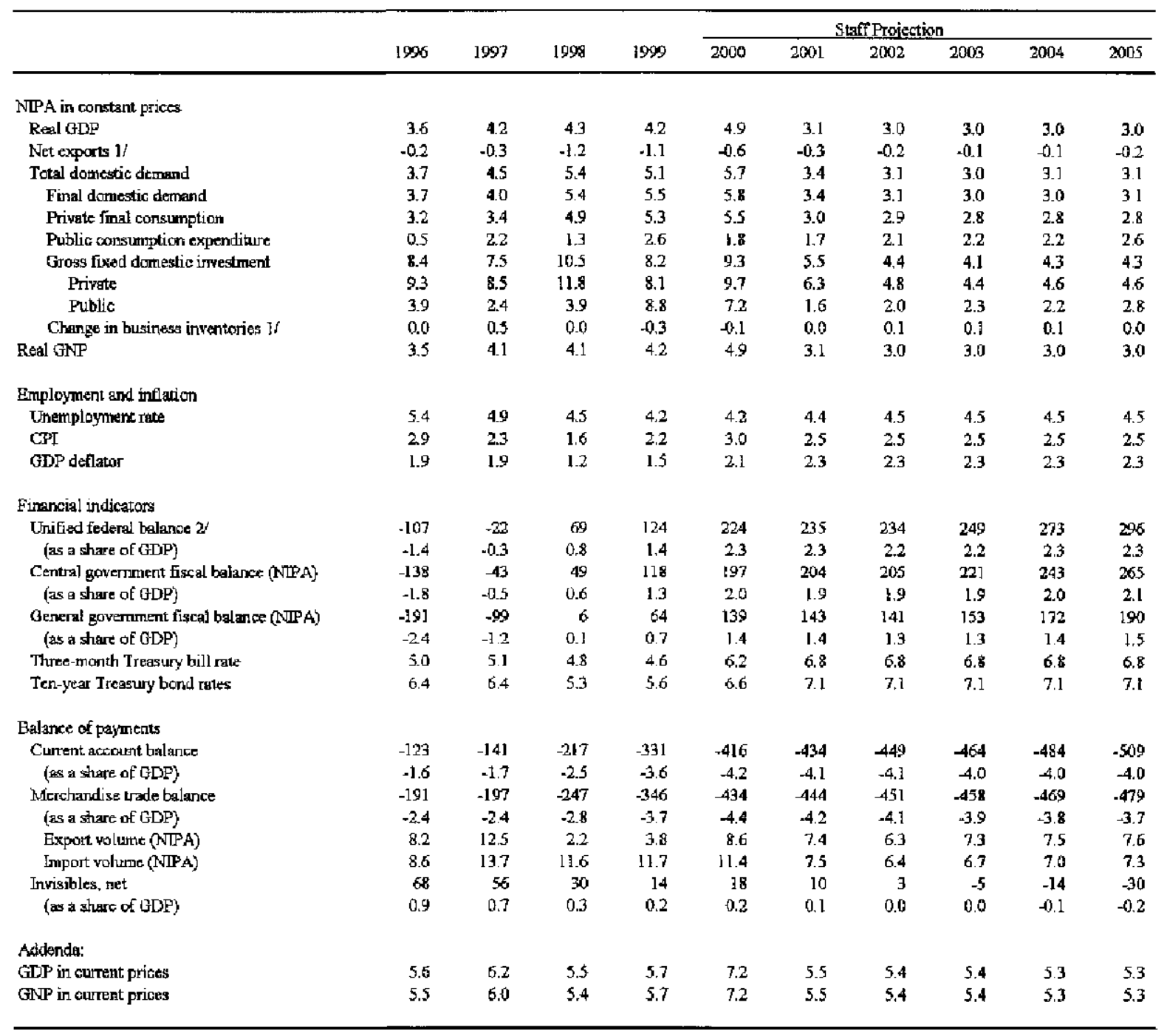

Source: Staff tstimates.

1/ Cottuibution to GDP gowth.

2/ Fiseal year. Projections assume that the Administrations F Y2001 budget proposal is adopted as described in the Mid-Session Review of the Inited States Govemment: Fiscal Year 2001 and repetsent staff estimates theot adjust for the difference between the Administration and staff macroeconoraic assumptions. 
Table 6. United States: "Harder Landing" Scenario

(Percent deviation from baseline levels, unless otherwise noted)

\begin{tabular}{lrrrrr}
\hline & 2000 & 2001 & 2002 & 2003 & 2004 \\
\hline World & & & & & \\
Real GDP & 0.7 & -0.9 & -0.7 & -0.5 & -0.2 \\
& & & & & \\
United States & & & & & \\
Real GDP & 0.5 & -2.0 & -1.9 & -1.3 & -0.6 \\
Domestic demand & 0.6 & -3.7 & -4.2 & -3.8 & -3.0 \\
Net private saving (percent of GDP) & -0.3 & 1.6 & 2.2 & 2.1 & 1.8 \\
Current account (billions of U.S. dollars) & -5.7 & 33.9 & 111.6 & 160.4 & 201.9 \\
CPI inflation & 0.3 & 0.8 & -0.7 & -0.6 & -0.2 \\
Short-term interest rate & 1.0 & 0.9 & 0.1 & -0.9 & -1.7 \\
Nominal effective exchange rate & 1.1 & -17.5 & -15.3 & -13.0 & -10.0
\end{tabular}

\section{Euro area}

Real GDP

Domestic demand

Net private saving (percent of GDP)

$\begin{array}{rrrrr}0.8 & -0.7 & -0.3 & -0.3 & -0.1 \\ 0.7 & 1.0 & 1.3 & 1.3 & 1.3 \\ -0.3 & -0.1 & -0.6 & -1.0 & -1.3 \\ 1.1 & 23.7 & 3.8 & -23.2 & -50.9 \\ 0.2 & -0.7 & -0.5 & -0.6 & -0.6 \\ 0.2 & -0.6 & -1.1 & -1.4 & -1.5 \\ -0.3 & 12.0 & 10.4 & 8.5 & 6.6\end{array}$

Current account (billions of U.S. dollars)

CPI inflation

Short-term interest rate

Nominal effective exchange rate

$\begin{array}{rrrrr}0.6 & -0.6 & -0.6 & -0.4 & 0.0 \\ 0.4 & 0.5 & 1.0 & 1.4 & 1.6 \\ -0.1 & -0.1 & -0.7 & 1.3 & -1.8 \\ 4.6 & 23.3 & -19.3 & -51.2 & -73.6 \\ 0.1 & -1.1 & -0.5 & -0.5 & -0.5 \\ 0.1 & -0.3 & -0.6 & -1.2 & -1.3 \\ -0.9 & 18.9 & 16.0 & 12.8 & 9.6\end{array}$

\section{Japan}

Real GDP

Domestic demand

Net private saving (percent of GDP)

Current account (billions of U.S. dollars)

CPI inflation

Short-term interest rate

Nominal effective exchange rate

Memorandum: Baseline

World

United States

Euro area

Japan

Developing countries

$\begin{array}{lllll}4.2 & 3.9 & 4.0 & 4.2 & 4.3 \\ 4.9 & 3.1 & 3.0 & 3.0 & 3.0 \\ 3.2 & 3.2 & 2.9 & 2.6 & 2.5 \\ 0.9 & 1.8 & 2.6 & 2.6 & 2.7 \\ 5.4 & 5.3 & 5.4 & 5.9 & 6.2\end{array}$

Source: MM, World Economic Outlook, May 2000. 
Table 7. United States: Fiscal Indicators, based on FY 2001 Budget (February 2000)

(In percent of GDP, fiscal years)

\begin{tabular}{llllllll}
\hline & \multicolumn{9}{c}{ Projections } \\
\cline { 4 - 8 } & 1999 & 2000 & 2001 & 2002 & 2003 & 2004 & 2005 \\
\hline
\end{tabular}

FY 2001 budget enrrent-servicos basseline

\begin{tabular}{|c|c|c|c|c|c|c|c|}
\hline \multicolumn{8}{|l|}{ Administration } \\
\hline Outtays & 18.7 & 18.5 & 18.4 & 17.9 & 17.8 & 17.6 & 17.4 \\
\hline Debt aervioe & 2.5 & 2.3 & 2.1 & 1.9 & 1.7 & 1.5 & 1.3 \\
\hline Other & 16.2 & 16.2 & 16.3 & 16.0 & 16.1 & 16.1 & 16.1 \\
\hline Revenue & 20.0 & 20.4 & 20.1 & 19.8 & 19.6 & 19.5 & 19.5 \\
\hline Unified balance & 1.4 & 1.9 & 1.7 & 1.9 & 1.8 & 1.8 & 2.0 \\
\hline Primary balanoe 1/ & 3.9 & 4.2 & 3.8 & 3.8 & 3.5 & 3.4 & 3.4 \\
\hline Unified balanoe excluding soolal eecnrity & 0.0 & 0.3 & 0.1 & 0.2 & 0.1 & 0.2 & 0.3 \\
\hline Debt 2 & 39.9 & 36.2 & 329 & 29.7 & 26.8 & 23.8 & 20.7 \\
\hline \multicolumn{8}{|l|}{ Staff } \\
\hline Guclays & & 18.2 & 17.9 & 17.4 & 17.1 & 16.8 & 16.5 \\
\hline Delbt servige & & 2.3 & 2.2 & 2.0 & 19 & 1.7 & 1.3 \\
\hline Other & & 15.9 & 15.7 & 15.4 & 15.3 & 15.1 & 15.0 \\
\hline Revenuo & & 20.3 & 20.1 & 19.9 & 19.6 & 19.6 & 19.6 \\
\hline Unified balance & & 2.1 & 2.2 & 2.5 & 2.5 & 2.8 & 3.1 \\
\hline Primary balance 1/ & & 4.4 & 4.3 & 4.5 & 4.4 & 4.5 & 4.6 \\
\hline Unified balance excluding social security & & 0.5 & 0.6 & 0.9 & 0.9 & 1.2 & 1.4 \\
\hline Debt $2 /$ & & 35.3 & 31.3 & 27.3 & 23.5 & 19.7 & 15.7 \\
\hline \multicolumn{8}{|l|}{ FY 2001 budget with proposed measures } \\
\hline \multicolumn{8}{|l|}{ Administration } \\
\hline Outlays & & 18.7 & 18.3 & 18.0 & 17.9 & 17.7 & 17.6 \\
\hline Debt service & & 23 & 2.1 & 1.9 & 1.7 & 1.5 & 1.4 \\
\hline Other & & 16.4 & 16.2 & 16.1 & 16.2 & 16.2 & 16.2 \\
\hline Revenue & & 20.4 & 20.1 & 19.8 & 19.5 & 19.4 & 19.4 \\
\hline Unified balanee & & 1.7 & 1.8 & 1.8 & 1.7 & 1.7 & 1.8 \\
\hline Primary balance $1 /$ & & 4.0 & 3.9 & 3.7 & 3.4 & 3.2 & 3.1 \\
\hline Uniffed balance excluding social security & & 0.2 & 0.2 & 0.1 & 0.0 & 0.0 & 0.0 \\
\hline Debt $2 /$ & & 36.3 & 32.9 & 29.8 & 27,0 & 24.2 & 21.3 \\
\hline \multicolumn{8}{|l|}{ Staff } \\
\hline Oullays & & 18.4 & 17.8 & 17.5 & 17.2 & 16.9 & 16.6 \\
\hline Debt service & & 2.3 & 2.2 & 20 & 1.9 & 1.7 & 1.5 \\
\hline Other & & 16.1 & 15.6 & 15.5 & 15.3 & 15.2 & 15.1 \\
\hline Revenue & & 20.3 & 20.1 & 19.9 & 19.6 & 19.5 & 19.5 \\
\hline Unified balance & & 1.9 & 2.3 & 24 & 2.4 & 2.6 & 2.9 \\
\hline Primary balanee $1 /$ & & 4.2 & 4.5 & 4.4 & 4.3 & 4.3 & 4.3 \\
\hline Unified balance exeluding social seourity & & 0.4 & 0.8 & 0.8 & 0.8 & 1.0 & 1.2 \\
\hline Debt $2 f$ & & 35.4 & 31.3 & 27.4 & 23.7 & 20.0 & 16.2 \\
\hline \multicolumn{8}{|l|}{ Memorundum items: } \\
\hline $\begin{array}{l}\text { Structural unified balance (staff) 3/ } \\
\text { Administration economic projections } \\
\text { (calendar years, in pereent) }\end{array}$ & & 1.8 & 1.9 & 2.3 & 2.4 & 2.7 & 3.1 \\
\hline Real GDP growth & & 3.3 & 2.7 & 2.5 & 2.5 & 2.8 & 3.0 \\
\hline CPI inflation rate & & 2.6 & 2.4 & 2.6 & 2.6 & 2.6 & 2.6 \\
\hline Three-month Treasury bill rate & & 5.2 & 5.2 & 5.2 & 5.2 & 5.2 & 5.2 \\
\hline
\end{tabular}

Sources: Budget of the United States Government: Fiseal Year 2001, and staff estimates. Staff estimates adjust the Administration projections for differences between the Administration and staff macroecononic assumptions.

1/ Excludes net interest outlays.

2/ Debt held by the pubtic includes debt held by the Federal Reserve Banks.

3/ As a percent of potential GDP, based on current services. 
Table 8. United Stares: Fiscal Indieators, based on Mid-Session Review (June 2000)

(In percent of GDP, fiscal years)

\begin{tabular}{|c|c|c|c|c|c|c|c|}
\hline & \multirow[b]{2}{*}{1999} & \multicolumn{6}{|c|}{ Projections } \\
\hline & & 2000 & 2001 & 2002 & 2003 & 2004 & 2005 \\
\hline \multicolumn{8}{|l|}{ FY2001 current-services baseline } \\
\hline \multicolumn{8}{|l|}{ Administration } \\
\hline Ouliays & 18.7 & 18.4 & 18.0 & 17.5 & $\mathbf{1 7 . 2}$ & 17.0 & 16.7 \\
\hline Debt service & 2.9 & 2.3 & 20 & 1.8 & 1,6 & 1.3 & 1.1 \\
\hline Other & 16.2 & 16.1 & 16.0 & 15.7 & 15.7 & 15.6 & 15.6 \\
\hline Revenue & 20.0 & 20.7 & 20.4 & 20.1 & 19.8 & 19.7 & 19.6 \\
\hline Unified balance & 1.4 & 2.3 & 2.3 & 26 & 2.6 & 2.7 & 2.9 \\
\hline Primary balance & 3.9 & 4.6 & 4,4 & 4.4 & 4.2 & 4.0 & 4.0 \\
\hline Unified balance excluding social sccurity & 0.0 & 0.8 & 0.8 & 1.0 & 0.9 & 1.0 & $\mathbf{1 . 1}$ \\
\hline Debt held by public & 39.9 & 35.3 & 31.1 & 27.1 & 23.4 & 19.6 & 15,9 \\
\hline \multicolumn{8}{|l|}{ Staff } \\
\hline Outipys & & 18.4 & 18.0 & 17.4 & 17.1 & 16.8 & 16.5 \\
\hline Debt service & & 2.3 & 2.1 & 1.9 & 1.7 & 1.4 & 1.2 \\
\hline Other & & 16.1 & 15.9 & 15.5 & 15.5 & 15.4 & 15.3 \\
\hline Revenue & & 20.7 & 20.4 & 20.1 & 19.8 & 19.7 & 19.6 \\
\hline Unified balance & & 2.3 & 24 & 2.7 & 2.7 & $2.8^{3}$ & 3,0 \\
\hline Frimary balance & & 4.6 & 4.5 & 4.5 & 4.3 & 4.3 & 42 \\
\hline Unified balance exclucing social security & & 0.8 & 0.8 & 1.0 & 1.0 & 1.1 & 1.3 \\
\hline Debt keld by pablio & & 35.2 & 30.9 & 26.8 & 22.8 & 19.0 & 15.0 \\
\hline \multicolumn{8}{|l|}{ FY 2001 Mid-Session Review } \\
\hline \multicolumn{8}{|l|}{ Adrimistratioñ } \\
\hline Outlays $1 /$ & & 18.5 & 18.2 & 18.0 & 17.7 & 17.5 & 17.4 \\
\hline Debt eervice & & 2.3 & 2.1 & 1.9 & 1.6 & 1.4 & 1.2 \\
\hline Other & & 16.2 & 16.1 & 16.1 & 15.1 & 16.1 & 16.1 \\
\hline Revente & & 20.7 & 20.4 & 20.1 & 19.8 & 19.6 & 19.5 \\
\hline Usified balance & & 2.2 & 2.2 & 2.1 & 2.1 & 2.1 & 2.1 \\
\hline Prinhary balance & & 4,5 & 4.3 & 3.9 & 3.7 & 3.6 & 3.4 \\
\hline Unified halance excluding social security & & 0.6 & 0.7 & 0.4 & 0.4 & 0.4 & 0.3 \\
\hline Debt held by public & & 35.5 & 31.4 & 27.9 & 24.6 & 21.4 & 18.3 \\
\hline \multicolumn{8}{|l|}{ Slaff } \\
\hline Outlays $\mathrm{H}$ & & 18.5 & 18.1 & 17.9 & 17.6 & 17.3 & 17.1 \\
\hline Debt service & & 2.3 & 2.1 & 1.9 & 1.7 & 1.5 & 1.3 \\
\hline Other & & 16.2 & 16.0 & 16.0 & 15.9 & 15.8 & 15.8 \\
\hline Revenue & & 20.7 & 20.4 & 20.1 & 19.8 & 19.6 & 19.5 \\
\hline Unifical balance & & 2.2 & 2.3 & 2.2 & 2.2 & 2.3 & 2.3 \\
\hline Primary balance & & 4.5 & 4.4 & 4.1 & 3.9 & 3.8 & 3.3 \\
\hline Unified balance exchuding social security & & 0.7 & 0.7 & 0.5 & 0.5 & 0.6 & 0.5 \\
\hline Debt held by puњlic & & 35.3 & $\mathbf{3 1 . 1}$ & 27.5 & 24.1 & 20.7 & 17.4 \\
\hline \multicolumn{8}{|l|}{ Memorandum jlems: } \\
\hline Structural unified balance (staff) 2 & & 2.1 & 2.1 & 2.4 & 2.5 & 2.7 & 3.0 \\
\hline \multicolumn{8}{|c|}{ Administration' economic projections (in percent, calendar-year basis) } \\
\hline Real GDP growth & & 4.8 & 3.2 & 3.1 & 3.0 & 2.9 & 2.9 \\
\hline CPI inflation & & 3.3 & 2.6 & 2.6 & 2.6 & 2.6 & 2.6 \\
\hline Throc-month Treasury bill rate & & 5.8 & 6.2 & 5.9 & 5.8 & 5.8 & 5.8 \\
\hline
\end{tabular}

Sources: Administration's Mid-Session Review of the FY 2001 Budget (June 2000), and staff estimates. Staff estimates adjust the Administration projections for differences between the Administration and staff macrocconomic assumptions.

1) Includes the "Reserve for America's future" that the Administration proposes to set aside over the next ten years for key thational priorities, such as retirement saving; targeted tax cuts; investment in education, research, health, and the environment; or finther debt reduction. The reserve amounts to $\$ 500$ billion, of which $\$ 123$ billian is totended for FY $2001-05$.

2) As a percent of potential GDP, based on current services. 
Table 9. Net Official Development Assistance Flows, 1998-99

\begin{tabular}{|c|c|c|c|c|}
\hline & \multicolumn{2}{|c|}{1998} & \multicolumn{2}{|c|}{1999} \\
\hline & $\begin{array}{l}\text { In millions of } \\
\text { U.S. dollars }\end{array}$ & $\begin{array}{l}\text { In percent } \\
\text { of GNP 1/ }\end{array}$ & $\begin{array}{l}\text { In millions of } \\
\text { U.S. dollars }\end{array}$ & $\begin{array}{l}\text { In percent } \\
\text { of GNP } 1 /\end{array}$ \\
\hline Australia & 960 & 0.27 & 981 & 0.26 \\
\hline Austria & 456 & 0.22 & 482 & 0.24 \\
\hline Belgium & 883 & 0.35 & 753 & 0.30 \\
\hline Canada & 1,691 & 0.29 & 1,721 & 0.28 \\
\hline Denmark & 1,704 & 0.99 & 1,724 & 1.00 \\
\hline Finland & 396 & 0.32 & 402 & 0.32 \\
\hline France & 5,742 & 0.40 & 5,494 & 0.38 \\
\hline Germany & 5,581 & 0.26 & 5,478 & 0.26 \\
\hline Greece & 179 & 0.15 & 260 & 0.21 \\
\hline Ireland & 199 & 0.30 & 241 & 0.31 \\
\hline Italy & 2,278 & 0.20 & 1,750 & 0.15 \\
\hline Japan & 10,640 & 0.28 & 15,302 & 0.35 \\
\hline Luxembourg & 112 & 0.65 & 115 & 0.64 \\
\hline Netherlands & 3,042 & 0.80 & 3,134 & 0.79 \\
\hline New Zealand & 130 & 0.27 & 134 & 0.27 \\
\hline Norway & 1,321 & 0.91 & 1,370 & 0.91 \\
\hline Portugal & 259 & 0.24 & 274 & 0.25 \\
\hline Spain & 1,376 & 0.24 & 1,347 & 0.23 \\
\hline Sweden & 1,573 & 0.72 & 1,643 & 0.70 \\
\hline Switzerland & 898 & 0.32 & 976 & 0.35 \\
\hline United Kingdom & 3,864 & 0.27 & 3,279 & 0.23 \\
\hline United States & 8,786 & 0.10 & 9,135 & 0.10 \\
\hline Total & 52,068 & 0.23 & 55,993 & 0.24 \\
\hline
\end{tabular}

Source: Development Assistance Committee (DAC) of the Organisation of Economic Co-operation and Development. Preliminary estimates.

I/ DAC members are progressively inlroducing a new system of national accounts, which is leading to slight upward revisions in measured GNP and corresponding declines in measured ODA/GNP ratios. 
Table 10. United States: Outlays for Foreign Assistance on a Budget Basis

(nn billions of dollars)

\begin{tabular}{|c|c|c|c|c|c|c|c|c|}
\hline & \multicolumn{8}{|c|}{ Fiscal Years } \\
\hline & 1993 & 1994 & 1995 & 1996 & 1997 & 1998 & 1999 & 2000 \\
\hline \multicolumn{9}{|c|}{ Outlays for foreign assistance by program } \\
\hline Agency for International Development & 3.32 & 3.40 & 4.10 & 3.94 & 3.70 & 3.62 & 3.44 & 3.77 \\
\hline Economic Support Fund & 3.23 & 2.77 & 2.74 & 2.24 & 2.23 & 2.46 & 2.35 & 2.36 \\
\hline Multilateral Development Banks & 1.16 & 1.36 & 1.40 & 1.72 & 1.81 & 1.53 & 1.47 & 1.41 \\
\hline Intemational Organizations & 0.38 & 0.31 & 0.50 & 0.30 & 0.31 & 0.30 & 0.34 & 0.30 \\
\hline PL 480 food aid & 1.44 & 1.73 & 1.37 & 1.08 & 0.89 & 0.94 & 1.26 & 1.72 \\
\hline \multicolumn{9}{|l|}{ Enterprises for the Americas Initiative } \\
\hline debt forgiveness & 0.00 & 0.00 & 0.02 & 0.03 & 0.00 & 0.02 & 0.03 & 0.09 \\
\hline Refugee Assistance & 0.67 & 0.7 & 0.71 & 0.64 & 0.72 & 0.72 & 0.73 & 0.92 \\
\hline Peace Corps & 0.21 & 0.21 & 0.23 & 0.21 & 0.23 & 0.22 & 0.24 & 0.26 \\
\hline Credit liquidating accounts & -1.01 & -0.50 & -0.52 & -1.44 & -1.51 & -1.76 & -1.57 & -1.31 \\
\hline Oftsetting receipts & -0.94 & -0.56 & -0.56 & -0.01 & 0.04 & 0.00 & 0.00 & 0.00 \\
\hline Other & 0.00 & 0.00 & 0.00 & 0.00 & 0.00 & 0.00 & 0.00 & 0.00 \\
\hline Total & 8.48 & 9.41 & 9.99 & 8.71 & 8.41 & 8.05 & 8.27 & 9.52 \\
\hline In percent of GDP & 0.2 & 0.1 & 0.1 & 0.1 & 0.1 & 0.1 & 0.1 & 0.1 \\
\hline
\end{tabular}

Source: U.S. Agency for International Development. 
Table 11. United States: Indicators of External and Financial Vulnerability

(In percent of GDP, unloss otherwise indicated)

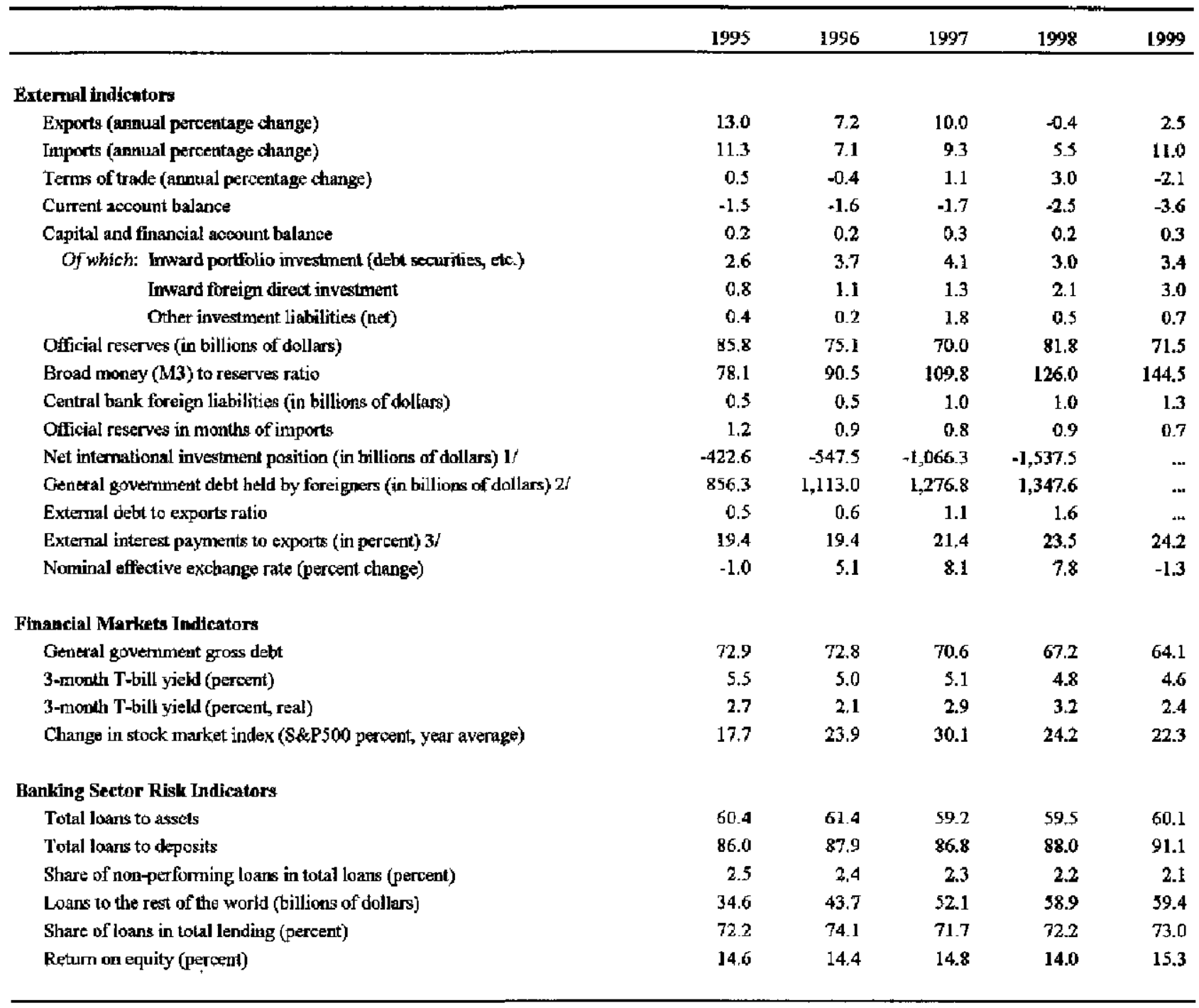

Sources: Board of Governors of the Federal Reserve System; and U.S. Department of Conmeree, Burcau of Economic Analysis.

1/ With direct investment positions at market value.

2/ Foreiga official assets (U.S. Government securities plus Treasury securities).

3/ External interest payments: income payments on foreign-owned assets (other priqate payments plus U.S. Government payments). 


\section{Statement by the IMF Staff Representative}

July 21, 2000

1. Since the staff report (SM/00/144, 6/30/00) was issued, the Chairman of the Federal Reserve Board, Mr. Alan Greenspan, presented the bianmual report to Congress on the economic situation and monetary policy; the Congressional Budget Office (CBO) provided an updated analysis of the budget and economic outlook; and new data releases continue to suggest that core inflation remains largely subdued. The thrust of the staff appraisal is unchanged by these developments.

\section{Chairman Greenspan's testimony}

2. In his congressional testimony on the Federal Reserve's Semiannial Report on Monetary Policy on July 20, Chairman Greenspan observed that growth in household spending had slowed noticeably in recent months. This suggested that the pace of aggregate demand growth may be moving closer in line with the rate of increase in the economy's productive potential. He noted that a number of accompanying developments suggested that this spending slowdown could persist; however, it was premature to make a definitive assessment. Mr. Greenspan indicated that, while signs of slower growth were evident and had justified not raising interest rates at the last FOMC meeting, these signs were not sufficiently compelling to alter the Committee's view that the risks remained more on the side of higher inflation.

3. Mr. Greenspan voiced continuing concerns regarding the tightness of labor markets and the potential for wage demands to begin to exceed increases in productivity. He also noted that the increase in core inflation in 2000 may largely reflect indirect effects of higher energy prices. Although energy price changes represented a one-time shift in a set of key prices, by themselves these generally could not fuel persistent inflation. The key to whether higher energy prices could result in persistent inflationary effects was in the response of inflation expectations. Mr. Greenspan pointed out that both survey evidence and rates on the Treasury's inflation-indexed bonds suggested that inflation expectations had not been affected by increases in energy prices.

4. Mr. Greenspan indicated that a central question underpinning the longer-term economic outlook was the extent to which a more subdued pace of production and consumer spending might be associated with a productivity slowdown. He said that the behavior of productivity as growth slowed to a more sustainable pace would be a revealing test of the extent to which rapid productivity growth in recent years has reflected structural versus cyclical factors. So far, there had been little evidence to undermine the belief that most of the productivity rise had been structural and, indeed, that structural productivity could still be accelerating.

5. Mr. Greenspan's remarks were considered by markets to be in line with expectations. Following the Chairman's remarks both stock and bond prices rose modestly. 


\section{CBO's budget outlook}

6. The CBO released The Bulget and Economic Outlook: An Update on July 18, 2000. The CBO's budget assessment is more favorable than that presented in April, mainly owing to higher revenue estimates arising from stronger projected economic growth. The $\mathrm{CBO}$ now projects that under current policies the unified federal budget surplus will be $\$ 232$ billion (2.4 percent of GDP) in FY 2000, and will reach $\$ 685$ billion (4.4 percent of GDP) in FY 2010; these projected surpluses are also somewhat higher than those projected by the Administration in the Mid-Session Review principally because of more favorable economic assumptions. Over the period FY 2001-10, the CBO projects cumulative on-budget surpluses under current policies of $\$ 2.2$ trillion; off-budget surpluses (principally Social Security) would total $\$ 2.4$ trillion.

\section{Recent economic data}

7. The unemployment rate fell slightly in June to 4.0 percent from 4.1 percent in May. Total nonfarm payroll employment edged up by just 11,000 jobs in June; job growth so far this year has averaged 177,000 per month compared to 202,000 in 1999. The core CPI rose by 0.2 percent in June, and by an annual rate of 2.0 percent in the second quarter of the year compared to 3.2 percent in the first quarter of 2000 . The core PPI fell 0.1 percent in June, rising by an annual rate of 0.8 percent in the second quarter compared to a 1.1 percent annual rate in the first quarter of the year. 


\section{INTERNATIONAL MONETARY FUND}

EXTERNAL

\section{Public Information Notice}

Public Information Notice (P|N) No. 00/52

FOR IMMEDIATE RELEASE

July 28,2000

International Monetary Fund

$70019^{\text {th }}$ Street, NW

Washington, D. C. 20431 USA

\section{IMF Concludes Article IV Consultation with the United States}

On July 21, 2000, the Executive Board concluded the Article IV consultation with the United States.

\section{Background}

Economic activity continued briskly in 1999 and through mid-2000, as the current expansion entered its $112^{\text {th }}$ month in July 2000 , the longest U.S. economic expansion on record. Real GDP grew by $41 / 4$ percent in 1999 , surging to a $6 \frac{1}{2}$ percent annual rate in the second half of the year, and slowing only slightly in the fitst quarter of 2000 to an annual rate of $51 / 2$ percent. Continued momentum in private consumption and investment remained the primary sources of strength, as growth in final demand remained at 51/2 percent in 1999 and rose to an 8 percent annual rate in the first quarter of 2000. Labor market conditions remained very tight with the unemployment rate around 4 percent in June 2000. Core inflation has been largely subdued owing in part to gains in labor productivity and weakness in non-oil import prices. Data for the early months of 2000 raised some concerns that price and wage pressures were beginning to emerge, but more recent data provide a more ambiguous picture. The core consumer price index (the CPI excluding food and energy prices) increased by 2 percent in 1999 and in early 2000 . After rising sharply in March, core inflation settled back down to 2 percent annual rate during the second quarter of 2000 .

By mid-1999, concerns about domestic demand growth in excess of the growth in potential output and further tightening in labor markets prompted the Federal Open Market Committee (FOMC) to tighten monetary policy. Over the period June 1999 to May 2000, the FOMC raised the federal funds rate by 175 basis points, including increases at four consecutive FOMC meetings, culminating in a 50 basis point increase in May. At its June meeting, the FOMC decided to leave the federal funds rate unchanged, but in its announcement following the meeting, the FOMC indicated that the risks

${ }^{1}$ Under Article IV of the IMF's Articles of Agreement, the IMF holds bilateral discussions with members, usually every year. A staff team visits the country, collects economic and financial information, and discusses with officials the country's economic developments and policies. On return to headquarters, the staff prepares a report, which forms the basis for discussion by the Executive Board. At the conclusion of the discussion, the Managing Director, as Chairman of the Board, summarizes the views of Executive Directors, and this summary is transmitted to the country's authorities. In this PIN, the main features of the Board's discussion are described. 
continued to be weighted mainly toward conditions that may generate heightened inflationary pressures in the foreseeable future.

The unified federal budget balance moved into surplus in FY1998 (3/4 percent of GDP) for the first time since FY 1969, and the surplus is expected to reach 21/4 percent of GDP in FY 2000.

Expenditure cuts and tax increases adopted as part of the Omnibus Budget and Reconciliation Act of 1993 have accounted for the steady improvement in the fiscal balance since 1992. In addition, policy actions contained in the Balanced Budget Agreement of 1997 helped to ensure a further improvement in the unified budget balance.

In real effective terms, the dollar appreciated by $3 \frac{1}{2}$ percent in 1999 and by a further $71 / 2$ percent in the first five months of 2000. A 12\%/4 percent depreciation against the yen during 1999 was more than offset by a $14 \%$ percent appreciation of the dollar against the euro. In the first five months of 2000 , the dollar appreciated modestly against the yen, but more sharply against the euro. In real effective terms, the dollar in May 2000 was 39 percent higher than its low in April-July 1995. The external current account deficit widened to about $3 \frac{1}{2}$ percent of GDP in 1999 from $21 / 2$ percent in 1998, largely owing to a further increase in the merchandise trade deficit, as import volume growth more than offset a pick-up in export volume growth that was driven by economic recovery in partner countries in the second half of 1999.

\section{Executive Board Assessment}

Executive Directors commended the authorities for their sound monetary and fiscal policies, which have contributed to making the current U.S. economic expansion the longest on record. Measures to improve the fiscal stance, together with the strength and duration of the current expansion, have resulted in a steady improvement in the federal fiscal balance since 1992. The outlook for sustained budget surpluses over the longer term holds out the prospect of eliminating the net federal government debt held by the public early in the next decade, an eventuality that Directors strongly supported in view of the longer-term fiscal pressures associated with the aging of the population. They noted that monetary policy has helped to sustain the expansion, which had provided significant support to the global recovery that appears to be well under way, while keeping U.S. inflation low.

Directors agreed that the remarkable strength of U.S. domestic demand growth has been supported by rising real incomes, enhanced profitability in the corporate sector, and rapidly growing household wealth-all closely related to the surge in productivity experienced in the United States in the second half of the 1990s. This productivity surge also had been a primary factor underlying the attractive investment environment in the United States, which has drawn in substantial flows of capital, contributing to a sharp widening of the current account deficit, against the background of historically low personal savings rates. Directors considered that the sustainability of current high stock market valuations will depend to a considerable extent on the duration of the factors underlying the surge in productivity growth, and thus the outlook for corporate earnings. At this juncture, while Directors recognized that judgment on how long this process might continue to support high levels of productivity growth-with their associated favorable effects on real incomes, profits, and wealth--is difficult, they agreed that continued domestic demand growth at a pace well in excess of the productivity-driven increases in potential output is not sustainable, and needs to be slowed. 
Directors agreed that the principal policy priority for the United States in the near term is to ensure that the pace of aggregate demand growth is brought back in line with the economy's potential growth in supply in order to keep inflation in check and the economic expansion on track. They strongly supported the policy actions of the Federal Reserve over the last year to slow the pace of demand growth. Most Directors considered that a further tightening of monetary policy could be required to ensure that inflation remains under control. However, Directors generally agreed that the need for further action to raise rates will depend on how the economy responds in the period immediately ahead to the restraining effects of monetary policy actions already in the pipeline, and if any additional indications of wage and price pressures emerge. Directors noted that, while monetary policy tightening in the United States has inevitable potentially adverse spillover effects on the rest of the world, the impact would be even more detrimental if the U.S. authorities unduly delay policy action, and subsequently tighten monetary policy more sharply once inflationary pressures strengthen.

Directors considered that fiscal policy will have an important role to play in restraining domestic demand growth in the near term, and supported the Administration's intention to preserve a substantial share of the fiscal surpluses in prospect. They emphasized the importance of resisting pressures to substantially cut taxes or raise spending, as these would add to demand pressures at an inappropriate time and thereby jeopardize the continued noninflationary expansion of the economy. Directors noted that maintaining a tight fiscal position would help raise the level of national savings, ensuring an orderly correction in the current account imbalance over the medium term and enabling the economy to sustain a continued high rate of investment.

From a longer-term perspective, the elimination of the net public debt will be an important step toward preparing the federal government for the coming long wave of unfunded liabilities associated with the aging of the population. Many Directors considered that a reasonable medium-term fiscal policy objective is to eliminate the actuarial imbalances facing Social Security and Medicare Hospital Insurance $(\mathrm{HI})$, and then aim at keeping the remainder of the budget roughly in balance on average over the business cycle. This objective might be facilitated if revenues and expenditures of Social Security and Medicare HI were more formally separated from the rest of the federal budget, in order to help mitigate pressures to divert surpluses in these programs to other uses. These Directors noted that the U.S. authorities are moving in this direction, having already placed Social Security offbudget and the Administration recommending to do the same with Medicare HI. Directors also suggested that continued fiscal discipline would be facilitated by extending discretionary spending caps and the PAYGO financing requirement through fiscal year 2010.

Several Directors noted that, with government debt being retired, the prospective disappearance of a risk-free benchmark could have potentially significant implications for international reserve management of other countries. They suggested that the staff further study the policy implications for the U.S. and for the world economy.

Directors supported the Administration's intention to address the longer-term imbalances facing Social Security and Medicare $\mathrm{HI}$, but some Directors questioned whether transferring general budgetary resources to these programs would be sufficient to address the imbalances. These Directors noted that under current estimates, relatively small adjustments in the parameters of both the Social Security and Medicare systems, if put in place soon. would be sufficient to meet the future liabilities of the programs. A few other Directors, however, cautioned that, under the present fiscal 
environment, increasing the regressive payroll tax may not be desirable, particularly on equity grounds. Resort to general revenues, on the other hand, could potentially erode an important budget constraint that had helped over the years to restrain spending on benefits. A number of Directors considered that supporting these programs with general revenue risks opening the door to subsequent on-budget transfers to finance further extensions of benefits.

Directors noted that the Administration continues its practice of proposing small targeted tax cuts to promote specific economic and social objectives. While recognizing that well-targeted tax credits may prove beneficial in a number of cases, they cautioned that overreliance on such tax expenditures adds to the complexity of the tax code, undermining transparency and increasing compliance costs. Directors encouraged the authorities to refrain from seeking measures that risk eroding the efficiency of the income tax system, especially when the underlying objectives are amenable to being addressed effectively through spending programs.

Directors congratulated the U.S. authorities on the adoption of the Gramm-Leach-Bliley Act, which represents a much needed overhaul of the outdated laws regulating the financial sector in the United States. The new regulatory supervisory structure and the expanded opportunities available under the law for new financial holding companies to engage in banking, securities, and insurance activities and the new regulatory supervisory structure pose significant new challenges. Among these is the central supervisory challenge to ensure that emerging larger, more complex financial institutions adopt sufficiently robust risk-management systems. Directors welcomed the authorities' intention to make more use of market information and discipline in supervising financial institutions. A few Directors encouraged the authorities to consider the preparation of a ROSC module on consolidated supervision.

Although Directors did not see any major vulnerabilities in the banking sector, they noted the high levels of household and corporate debt, and they agreed that any substantial downturn in the economy would inevitably produce some financial distress, with falling incomes and profits creating debt-servicing difficulties for some households and businesses. In this context, they strongly supported the authorities' efforts to pre-emptively limit the scope of such potential future financial distress by cautioning bank lending officers against loosening lending standards and basing loan decisions on tenuous extrapolations of the current favorable economic conditions.

Directors observed that, as a general rule, the Administration has supported and promoted enhanced market competition throughout the economy. In this context, they commended the authorities for the improvements in market access provided by the recently enacted African Growth and Opportunity Act and the Caribbean Basin Initiative. Noting the increase in antioumping (AD) and countervailing duty (CVD) actions in the past two years, many Directors suggested that the authorities consider changing the administration of AD/CVD procedures in a way that makes import protection available only in those cases where foreign producers are found to be engaged in anticompetitive behavior.

Directors expressed concern about the low level of U.S. official development assistance as a ratio of GNP, and urged the authorities to strengthen their commitment in this area. They welcomed the Administration's support for the enhanced HIPC Initiative, and encouraged the U.S. government to complete the necessary financing arrangements. 
Directors noted that the quality, coverage, periodicity, and timeliness of U.S. economic data are considered to be excellent both in the context of the Article IV consultation and for purposes of ongoing surveillance.

Public Information Notices (PINs) are issued, (i) at the request of a member country, following the conclusion of the Article JV consultation for countries seeking to make known the views of the IMF to the public. This action is intended to strengthen IMF surveillance over the economic policies of member countries by increasing the transparency of the IMF's assessment of these policies; and (ii) following policy discussions in the Executive Board at the decision of the Board. As part of a pilot project, the staff report for the 2000 Article IV consultation with the United States is also available. 


\begin{tabular}{|c|c|c|c|c|c|c|c|c|c|}
\hline & \multicolumn{3}{|c|}{ Averages } & \multirow[b]{2}{*}{1994} & \multirow[b]{2}{*}{1995} & \multirow[b]{2}{*}{1996} & \multirow[b]{2}{*}{1997} & \multirow[b]{2}{*}{1998} & \multirow[b]{2}{*}{1989} \\
\hline & $1960 \mathrm{~s}$ & $1970 \mathrm{~s}$ & $1980 \mathrm{~s}$ & & & & & & \\
\hline \multicolumn{10}{|l|}{ Economic activity and prioes } \\
\hline Real GDP & 4.4 & 3.3 & 3.0 & 4.0 & 2.7 & 3.6 & 4.2 & 4.3 & 4.2 \\
\hline Real net exports $1 /$ & 0.0 & 0.2 & -0.1 & -0.4 & 0.1 & -0.2 & -0.3 & -1.2 & -1.1 \\
\hline Real final domestic demand & 4.4 & 3.1 & 3.0 & 3.8 & 3.0 & 3.7 & 4.0 & 5.4 & 5.5 \\
\hline Private final consumplion & 4.4 & 3.5 & 3.2 & 3.8 & 3.0 & 3.2 & 3.4 & 4.9 & 5.3 \\
\hline Nonresidential fixed investment & 7.2 & 5.4 & 3.3 & 8.9 & 9.8 & 10.0 & 10.7 & 12.7 & 8.3 \\
\hline Labor force & 1.7 & 2.7 & 1.7 & 1,4 & 1.0 & 1.2 & 1.8 & 1.0 & 1.2 \\
\hline Employment & 1.9 & 2.4 & 1.7 & 2.3 & 1.5 & 1.4 & 2.2 & 1.5 & 1.5 \\
\hline Unemployment rate & 4.8 & 6.2 & 7.3 & 6.1 & 5.6 & 5.4 & 4.9 & 4.5 & 4.2 \\
\hline Labor productivity $2 /$ & 2.9 & 2.0 & 1.4 & 1.3 & 0.9 & 2.6 & 1.6 & 2.8 & 3.0 \\
\hline Total factor productivity $2 /$ & 1.9 & 1.1 & 0.1 & 0.4 & 0.3 & 1.5 & 0.4 & $\ldots$ & $\ldots$ \\
\hline Capital stock $3 t$ & $3 . \bar{T}$ & 3.5 & 2.7 & 2.3 & 2.4 & 2.8 & 2.9 & 3.3 & $\ldots$ \\
\hline GDP deflator & 2.4 & 6.6 & 4.8 & 2.1 & 2.2 & 1.9 & 1.9 & 1.2 & 1.5 \\
\hline Implicit price deflator for GDP & 2.4 & 6.6 & 4.8 & 2.1 & 2.2 & 1.9 & 1.9 & 1.2 & 1.5 \\
\hline Consumer price index & 2.3 & 7.1 & 5.6 & 2.6 & 2.8 & 2.9 & 2.3 & 1.6 & 2.2 \\
\hline Unit labor cost 2 & 2.1 & 6.3 & 4.3 & 0.8 & 1.2 & 0.5 & 1.9 & 2.4 & 1,6 \\
\hline Nominal effective exchange rate 4 & 0.5 & -2.4 & 0.2 & -1.8 & -6.0 & 5.2 & 8.1 & 4.9 & -2.5 \\
\hline Real effective exchange rate $4 /$ & $\ldots$ & $\ldots$ & $\ldots$ & -1.0 & -6.4 & 6.0 & 8.9 & 6.7 & 1.0 \\
\hline Three-month Treasury bill rate (percent) 5 & 4.0 & 6.3 & 8.8 & 4.2 & 5.5 & 5.0 & 5.1 & 4.8 & 4.6 \\
\hline Ten-year Treasury note rate (percent) $5 /$ & 4.7 & 7.5 & 10.6 & 7.1 & 6.6 & 6.4 & 6.4 & 5.3 & 5.6 \\
\hline \multicolumn{10}{|c|}{ (In percent of GDP or NNP) } \\
\hline Balance of payments & & & & & & & & & \\
\hline Cursent account & 0.5 & 0.0 & -1.7 & -1.7 & -1.5 & -1.6 & -1.7 & -2.5 & -3.6 \\
\hline Merchandise trade balance & 0.6 & -0.5 & -2.2 & -2.4 & -2.3 & -2.4 & -2.4 & -2.8 & -3.7 \\
\hline Invisibles, net & -0.1 & 0.5 & 0.5 & 0.7 & 0.9 & 0.9 & 0.7 & 0.3 & 0.2 \\
\hline Real net exports $6 /$ & -1.2 & $-1,4$ & -1.5 & -1.2 & -1.0 & -1.1 & -1.4 & -2.6 & -3.7 \\
\hline \multicolumn{10}{|l|}{ Fiscal Indlcators } \\
\hline Unified Federal balance (Fiscal year) & -0.8 & -2.1 & -3.9 & -2.9 & -2.2 & -1.4 & -0.3 & 0.8 & 1.4 \\
\hline Struciural Balance (Fiscal year) $7 /$ & & & & -2.1 & -1.5 & -0.7 & 0.2 & 1.1 & 1.4 \\
\hline Central government fiscal balance (NIPA) dl & -0.1 & -1.7 & -3.8 & -3.0 & -2.6 & -1.8 & -0.5 & 0.6 & $\cdots$ \\
\hline General government fiscal balance (N|PA) 8 & -1.2 & -2.4 & -4.4 & -3.8 & -3.3 & -2.4 & -1.2 & 0.1 & $\cdots$ \\
\hline \multicolumn{10}{|l|}{ Savings and investment $9 /$} \\
\hline Gross national saving & 21.0 & 19.7 & 18.5 & 16.4 & 17.0 & 17.3 & 18.3 & 18.8 & 18.7 \\
\hline General government & 4.0 & 1.3 & -0.8 & -0.6 & -0.1 & 0.8 & 1.9 & 3.1 & 3.9 \\
\hline Of which: Federal government & 2.2 & -0.5 & -2.2 & -1.9 & -1.5 & -0.7 & 0.5 & 1.5 & 2.2 \\
\hline Private & 17.1 & 18.4 & 19.2 & 17.0 & 17.1 & 16.5 & 16.4 & 15.7 & 14.7 \\
\hline Personal & 5.7 & 6.8 & 6.7 & 4.5 & 4.1 & 3.5 & 3.3 & 2.6 & $1 . J$ \\
\hline Business & 11.4 & 11.6 & 12.6 & 12.5 & 13.0 & 13.0 & 13.1 & 13.0 & 13.1 \\
\hline Gross domestic Investment & 20.7 & 20.4 & 20.5 & 18.8 & 18.7 & 19.1 & 19.8 & 20.5 & 20.7 \\
\hline Private & 15.5 & 16.7 & 16.9 & 15.6 & 15.5 & 15.9 & 16.7 & 17,5 & 17.5 \\
\hline Public & 5.2 & 3.7 & 3.6 & 3.2 & 3.2 & 3.2 & 3.1 & 3.1 & 3.2 \\
\hline Of which: Federal government & 24 & 1.3 & 1.5 & 1.2 & 1.1 & 1.1 & 1.0 & 1.0 & 1.0 \\
\hline Net foreign investment & 0.6 & 0.2 & -1.5 & -1.5 & -1.3 & -1.4 & -1.5 & -2.3 & -3.4 \\
\hline Net national saving & 15.0 & 12.4 & 9.3 & 7.1 & 7.9 & 8.3 & 9.5 & 10.0 & 9.7 \\
\hline Net private investment & 8.8 & 9.0 & 7.5 & 6.2 & 6.1 & 6.7 & 7.6 & 8.5 & 8.4 \\
\hline \multicolumn{10}{|l|}{ In real terms } \\
\hline Gross domestic investment & 17.1 & 16.6 & 17.3 & 18.3 & 18.3 & 19.1 & 20.2 & 21.3 & 21.6 \\
\hline Private & 12.4 & 13.6 & 14.1 & 15.1 & 15.1 & 15.9 & 17.0 & 18.2 & 18.5 \\
\hline Public & 4.7 & 3.0 & 3.1 & 3.2 & 3.2 & 3.2 & 3.1 & 3.1 & 3.1 \\
\hline
\end{tabular}

Sources: U.S. Department of Commerce, Bureau of Econcmic Analysis; and Board of Governors of the Federal Reserve System.

1/ Contribution to GDP growth.

2 Private nonfarm business sector.

3. Business sector; in chained 1996 dollars except for historical averages which are in chained 1992 dollars.

4/ Monthly average on a unit labor cost basis $(1990=100)$.

5/ Yearly average.

6/ On a NIPA basis.

$7 /$ As a percent of potential GDP.

8/ Overall balance - i.e., current balance minus net investment

9/ Gross nattonal saving does not equal gross domestic investment and net foreign investment because of capital grants and statistical discrepancy. Net national saving and net private investment are expressed in percent of NNP. 